UNIVERSIDADE DE SÃO PAULO

ESCOLA DE ENFERMAGEM

VLADIMIR ARAUJO DA SILVA

BEM-ESTAR ESPIRITUAL DECORRENTE DA AUDIÇÃO PASSIVA DE MÚSICA SACRA EM FAMILIARES ENLUTADOS: ENSAIO CLÍNICO RANDOMIZADO 
VLADIMIR ARAUJO DA SILVA

\title{
BEM-ESTAR ESPIRITUAL DECORRENTE DA AUDIÇÃO PASSIVA DE MÚSICA SACRA EM FAMILIARES ENLUTADOS: ENSAIO CLÍNICO RANDOMIZADO
}

\author{
Versão Corrigida da Tese apresentada ao Programa de Pós-Graduação \\ em Enfermagem na Saúde do Adulto da Escola de Enfermagem da \\ Universidade de São Paulo para a obtenção do título de Doutor em \\ Ciências. \\ Área de concentração: Enfermagem na Saúde do Adulto \\ Orientadora: Prof ${ }^{\mathrm{a}}$. Dr ${ }^{\mathrm{a}}$. Maria Júlia Paes da Silva
}

\section{VERSÃO CORRIGIDA}

A versão original encontra-se disponível na Biblioteca da Escola de Enfermagem da Universidade de São Paulo e na Biblioteca Digital de Teses e Dissertações da Universidade de São Paulo. 
AUTORIZO A REPRODUÇÃO E DIVULGAÇÃO TOTAL OU PARCIAL DESTE TRABALHO, POR QUALQUER MEIO CONVENCIONAL OU ELETRÔNICO, PARA FINS DE ESTUDO E PESQUISA, DESDE QUE CITADA A FONTE.

Assinatura:

Data:

Bem-estar espiritual decorrente da audição passiva de música sacra em familiares enlutados: ensaio clínico randomizado / Vladimir Araujo da Silva. São Paulo, 2015. 155 p.

Tese (Doutorado) - Escola de Enfermagem da Universidade de São Paulo.

Orientadora: Prof. ${ }^{\text {a }}$ Dr. ${ }^{\text {a }}$ Maria Júlia Paes da Silva

Área de concentração: Enfermagem na Saúde do Adulto

1. Enfermagem oncológica. 2. Terapias complementares. 3. Musicoterapia. 4. Cuidados paliativos. 5. Espiritualidade. I. Título. 
Nome: Vladimir Araujo da Silva

Título: Bem-estar espiritual decorrente da audição passiva de música sacra em familiares enlutados: ensaio clínico randomizado.

Tese apresentada ao Programa de Pós-Graduação em Enfermagem na Saúde do Adulto da Escola de Enfermagem da Universidade de São Paulo para a obtenção do título de Doutor em Ciências.

Aprovado em:

\section{Banca Examinadora}

$\operatorname{Prof}^{\mathrm{a}} . \mathrm{Dr}^{\mathrm{a}}$. Instituição:

Julgamento: Assinatura:

Prof $^{a} . D^{a}$ Instituição:

Julgamento: Assinatura:

Prof $^{\mathrm{a}} . \mathrm{Dr}^{\mathrm{a}}$. Instituição:

Julgamento: Assinatura:

Prof $^{a} . D^{a}$ Instituição:

Julgamento: Assinatura:

$\operatorname{Prof}^{\mathrm{a}} . \mathrm{Dr}^{\mathrm{a}}$ Instituição:

Julgamento: Assinatura: 


\section{DEDICATÓRIA}

À minha esposa Rita de Cássia Frederico Silva, por me amar e me fazer feliz, por ser a mulher da minha vida e mãe dos meus filhos. Por todo o suporte na minha trajetória acadêmica, e, especialmente, por seu esforço, carinho e dedicação ao me acompanhar, tocando flauta doce, nas intervenções musicais. Obrigado por fazer parte da minha vida.

Aos meus filhos e razão da minha existência, Matheus Anthoani Frederico Silva e João Henrique Frederico Silva, por compreenderem a razão da minha ausência e o tempo limitado para brincar e dar a atenção que merecem.

Aos familiares enlutados, participantes desta pesquisa, pelo tempo que reservaram para me receber. Que Deus os abençoe, conforte os seus corações e conceda a paz e o descanso eterno a seus entes queridos. 


\section{AGRADECIMENTOS}

À Deus, pelo dom da vida, por Sua benção e proteção, por Sua presença em minha vida, por iluminar os meus caminhos e conduzir os meus passos.

À Nossa Senhora Aparecida, por sua benção e intercessão.

À Prof ${ }^{\mathrm{a}}$. Dr ${ }^{\mathrm{a}}$. Maria Júlia Paes da Silva, um ser humano muito especial, que eu tenho a honra e o privilégio de ter como mestre. A ela, todo o meu respeito, admiração e eterna gratidão, por sua amizade e orientação, por todo o conhecimento compartilhado, pelo acolhimento, pela parceria e companheirismo, pelas vibrações energéticas e pelo carinho.

À Banca Examinadora, pelo carinho e relevantes contribuições.

Aos meus pais Ademir Batista da Silva e Adelaide Araujo da Silva, pela vida, por todo o amor, carinho e cuidado, e pela formação educacional, moral e religiosa.

À minha avó materna, Emília de Souza Araujo, pela dedicação e carinho incondicional, e pelo incentivo à minha formação acadêmica.

À minha avó paterna, Anésia de Albuquerque Araujo, por sua benção e orações.

Aos amigos que conquistei nos Grupos de Pesquisa "Estudo das Práticas Alternativas ou Complementares de Saúde" e "Estudo e Pesquisa sobre Comunicação em Enfermagem" e que tanto contribuíram na construção do meu conhecimento.

À Universidade de São Paulo - USP, especialmente à Escola de Enfermagem EEUSP, pelos recursos humanos, científicos e tecnológicos disponibilizados, especialmente pelas contribuições do corpo docente e do estatístico Bernardo Pereira dos Santos.

Ao Programa de Pós-Graduação em Enfermagem na Saúde do Adulto - PROESA, pela oportunidade de integrar o seu corpo discente, sobretudo pela concessão de uma bolsa de estudos, por meio do Programa de Excelência Acadêmica - PROEX, em parceria com a Coordenação de Aperfeiçoamento de Pessoal de Nível Superior - CAPES, à qual estendo o meu agradecimento. 
Silva VA. Bem-estar espiritual decorrente da audição passiva de música sacra em familiares enlutados: ensaio clínico randomizado [tese]. São Paulo: Escola de Enfermagem, Universidade de São Paulo; 2015.

\section{RESUMO}

Introdução: A música constitui um recurso de cuidado capaz de integrar todas as dimensões humanas e direcionar questionamentos e reflexões acerca do significado da vida e sua finitude, subsidiando a expressão da espiritualidade e a compreensão do sentido da vida. Objetivo: Avaliar os efeitos da musicoterapia no bem-estar espiritual de familiares enlutados. Método: Trata-se de um ensaio clínico randomizado, com abordagem quantitativa. Os participantes foram alocados aleatoriamente para o Grupo 1 - controle, sem intervenção, Grupo 2 - experimental, com música sacra cantada ao vivo, e Grupo 3 - experimental, com música sacra instrumental ao vivo. A pesquisa foi realizada nas residências de usuários cadastrados na Rede Feminina de Combate ao Câncer de Maringá-PR, após aprovação do Comitê de Ética e Pesquisa da Escola de Enfermagem da Universidade de São Paulo. A amostra foi composta por familiares enlutados pela morte de pacientes oncológicos, há pelo menos um mês e no máximo 12 meses, residentes nos municípios de Maringá, Sarandi ou Paiçandu, com idade igual ou superior a 18 anos, função auditiva referida preservada e função da linguagem preservada, que participaram do processo de cuidado no fim da vida de seu ente querido e aceitaram participar da pesquisa. A coleta de dados ocorreu entre janeiro de $2014 \mathrm{e}$ março de 2015, por meio da utilização de um formulário semiestruturado e da Escala de BemEstar Espiritual (EBE), subdividida em Bem-Estar Religioso (BER) e o Bem-Estar Existencial (BEE), aplicada antes e após a intervenção. Foram utilizadas três músicas sacras brasileiras (Vossa presença faz viver; Prece ao Deus vivo; Quando a dor chegar), pré-selecionadas e executadas ao vivo, pelo pesquisador e uma flautista, utilizando voz (tenor), violão acústico e flauta doce (contralto), em quatro sessões de audição passiva, com duração de 20 minutos, uma vez por semana, de forma individual ou em grupo. Foram realizadas análises estatísticas descritivas e inferenciais, por meio dos testes Qui-Quadrado ou Análise de Variância, ao nível de 5\% de significância. Resultados: No total, 69 familiares enlutados participaram do estudo, (27,5\% cônjuges e 72,5\% filhos), sendo alocados, aleatoriamente, 23 em cada grupo. As médias dos escores gerais de Bem-Estar Espiritual, antes e após a intervenção, foram, respectivamente: 106,4 e 105,5 no Grupo 1; 103,2 e 105,2 no Grupo 2; 107,4 e 108,7 no Grupo 3. Para o BER as médias foram: 57,9 e 56,9 no Grupo 1, 56,3 e 56,4 no Grupo 2, 57,4 e 58,1 no Grupo 3. Para o BEE as médias foram: 48,5 e 48,6 no Grupo 1, 46,9 e 48,9 no Grupo 2, 49,9 e 50,7 no Grupo 3. Os Coeficientes Alfa de Cronbach, antes e após a intervenção $(0,826$ e 0,848$)$ demonstram alta confiabilidade nas respostas dos participantes em relação à EBE. Conclusão: Embora não sejam estatisticamente significativos, os resultados sugerem que a musicoterapia pode melhorar o bem-estar espiritual de familiares enlutados, e que a música sacra cantada pode subsidiar melhores níveis de bem-estar espiritual quando comparada à música sacra instrumental.

PALAVRAS-CHAVE: Enfermagem oncológica. Terapias complementares. Musicoterapia. Cuidados paliativos. Espiritualidade. 
Silva VA. Spiritual well-being resulting from passive listening of sacred music in bereaved relatives: randomized controlled trial [thesis]. São Paulo: School of Nursing, University of São Paulo; 2015.

\begin{abstract}
Introduction: Music is a care facility able to integrate all human dimensions and direct questions and reflections about the meaning of life and its finitude, supporting the expression of spirituality and understanding the meaning of life. Objective: To evaluate the effects of music therapy on spiritual well-being of bereaved relatives. Method: This is a randomized clinical trial with a quantitative approach. The participants were randomly allocated to Group 1 - control, without intervention, Group 2 - experimental, with live sung sacred music and Group 3 - experimental, with live instrumental sacred music. The survey was conducted in the residences of the registered users in the Women's Network Against Cancer of MaringaPR, after approval by the Research Ethics Committee of the School of Nursing of the University of São Paulo. The sample consisted of bereaved relatives by the death of cancer patients for at least one month and a maximum of 12 months, residents in the cities of Maringá, Sarandi or Paiçandu, aged over 18 years, preserved referred auditory function and preserved function of language, who participated in the care process at the end of life of their loved one and agreed to participate. Data collection took place between January 2014 and March 2015, through the use of a semi-structured form and of the Spiritual Well-Being Scale (SWBS), subdivided into Religious Well-Being (RWB) and the Existential Well-Being (EWB), applied before and after the intervention. Three Brazilian sacred music were used (Your presence gives life; Prayer to the living God: When the pain arrive), preselected and performed live by researcher and a flutist, using voice (tenor), acoustic guitar and flute (alto), in four 20-minute passive listening sessions, once a week, individually or in groups. Descriptive statistical analyzes were performed, and inferential analysis through the ChiSquare or Analysis of Variance tests, at 5\% significance level. Results: In total, 69 bereaved relatives participated in the study $(27.5 \%$ spouses and children $72.5 \%)$, being allocated randomly, 23 in each group. The mean of the overall scores of Spiritual Well-Being before and after the intervention, were, respectively: 106.4 and 105.5 in Group 1; 103.2 and 105.2 in Group 2; 107.4 and 108.7 in Group 3. For the RWB the means were 57.9 and 56.9 in Group 1, 56.3 and 56.4 in Group 2, 57.4 and 58.1 in Group 3. For the EWB the means were 48.5 and 48.6 in Group 1, 46.9 and 48.9 in Group 2, 49.9 and 50.7 in Group 3. The Cronbach's Alpha Coefficients before and after intervention (0.826 and 0.848) demonstrate high reliability in the answers of the participants with regard to SWBS. Conclusion: Although not statistically significant, the results suggest that music therapy can improve the spiritual well-being of bereaved relatives, and the sung sacred music can support higher levels of spiritual well-being compared to instrumental sacred music.
\end{abstract}

KEYWORDS: Oncology Nursing. Complementary therapies. Music Therapy. Palliative Care. Spirituality. 


\section{LISTA DE ILUSTRAÇÕES}

Figura 1 - Dimensões do ser humano: $\varphi$ física, $\psi$ psíquica, $\gamma$ familiar-financeira, $\delta$ social-cultural, $\varepsilon$ existencial, $\zeta$ espiritual e $\alpha \omega$ transcendente.

Figura 2 - Fluxograma de inclusão e exclusão dos participantes: adaptado do CONSORT 2010 Flow Diagram. Maringá, PR, Brasil, 2015.

Figura 3 - Comparação entre grupos dos efeitos da musicoterapia no Bem-Estar Espiritual (EBE) dos familiares enlutados. Maringá, PR, Brasil, 2015.

Figura 4 - Comparação entre grupos dos efeitos da musicoterapia no Bem-Estar Religioso (BER) dos familiares enlutados. Maringá, PR, Brasil, 2015.

Figura 5 - Comparação entre grupos dos efeitos da musicoterapia no Bem-Estar Existencial (BEE) dos familiares enlutados. Maringá, PR, Brasil, 2015. 


\section{LISTA DE TABELAS}

Tabela 1 - Nível de escolaridade dos familiares enlutados. Maringá, PR, Brasil, 2015.

Tabela 2 - Estado civil dos familiares enlutados. Maringá, PR, Brasil, 2015.

Tabela 3 - Religião dos familiares enlutados. Maringá, PR, Brasil, 2015.

Tabela 4 - Importância da religião para os familiares enlutados. Maringá, PR, Brasil, 2015.

Tabela 5 - Frequência em missas/cultos dos familiares enlutados. Maringá, PR, Brasil, 2015.

Tabela 6 - Apreciação musical dos familiares enlutados. Maringá, PR, Brasil, 2015.

Tabela 7 - Educação musical dos familiares enlutados. Maringá, PR, Brasil, 2015.

Tabela 8 - Tempo de estudo dos familiares enlutados que tiveram educação musical. Maringá, PR, Brasil, 2015.

Tabela 9 - Habilidade de tocar instrumentos musicais dos familiares enlutados. Maringá, PR, Brasil, 2015.

Tabela 10 - Hábito de ouvir música dos familiares enlutados. Maringá, PR, Brasil, 2015.

Tabela 11 - Músicos nas famílias dos familiares enlutados. Maringá, PR, Brasil, 2015.

Tabela 12 - Grau de parentesco ( $1^{\mathrm{a}}$ resposta) dos entes queridos relacionados às experiências pregressas de morte/luto dos familiares enlutados. Maringá, PR, Brasil, 2015.

Tabela 13 - Estilo de apego dominante dos familiares enlutados, em relação aos seus entes queridos. Maringá, PR, Brasil, 2015.

Tabela 14 - Duração do processo de morte e morrer dos entes queridos dos familiares enlutados. Maringá, PR, Brasil, 2015.

Tabela 15 - Distribuição dos familiares enlutados segundo a opção de seguir o tratamento médico proposto para o seu ente querido. Maringá, PR, Brasil, 2015.

Tabela 16 - Circunstância da morte dos entes queridos dos familiares enlutados. 
Tabela 17 - Distribuição dos familiares enlutados em relação à conspiração de silêncio. Maringá, PR, Brasil, 2015.

Tabela 18 - Uso de antidepressivo pelos familiares enlutados, após a morte de seus entes queridos. Maringá, PR, Brasil, 2015.

Tabela 19 - Uso de outro medicamento pelos familiares enlutados, após a morte de seus entes queridos. Maringá, PR, Brasil, 2015.

Tabela 20 - Distribuição dos familiares enlutados em relação ao apoio social/comunitário após a morte de seus entes queridos. Maringá, PR, Brasil, 2015.

Tabela 21 - Distribuição dos familiares enlutados em relação ao tratamento psicológico após a morte de seus entes queridos. Maringá, PR, Brasil, 2015.

Tabela 22 - Distribuição dos familiares enlutados em relação ao apoio espiritual/religioso após a morte de seus entes queridos. Maringá, PR, Brasil, 2015.

Tabela 23 - Níveis de Bem-Estar Espiritual (EBE), Bem-Estar Religioso (BER) e Bem-Estar Existencial (BEE), dos familiares enlutados. Maringá, PR, Brasil, 2015.

Tabela 24 - Efeitos de interação e intervenção, antes e após a intervenção. Maringá, PR, Brasil, 2015.

Tabela 25 - Análise individual dos 20 itens da EBE em relação à validação interna. Maringá, PR, Brasil, 2015.

Tabela 26 - Apreciação estética dos familiares enlutados, em relação à música que mais gostaram de ouvir. Maringá, PR, Brasil, 2015.

Tabela 27 - Sentimentos percebidos pelos familiares enlutados após a intervenção. Maringá, PR, Brasil, 2015.

Tabela 28 - Razão da escolha musical dos familiares enlutados após a intervenção. Maringá, PR, Brasil, 2015.

Tabela 29 - Correlação entre sentimentos percebidos e razão da escolha musical dos familiares enlutados após a intervenção. Maringá, PR, Brasil, 2015.

Tabela 30 - Correlação entre variáveis e a diferença entre os níveis de EBE dos familiares enlutados antes e após a intervenção. Maringá, PR, Brasil, 2015.

Tabela 31 - Correlação entre variáveis e a diferença entre os níveis de EBE dos familiares enlutados, antes e após a intervenção. Maringá, PR, Brasil, 2015. 


\section{LISTA DE SIGLAS}

AAMT

ANOVA

$\mathrm{Cd}$

$\mathrm{CP}$

CT

CNS

COFEN

COMEP

D

Dc

DeCS

DP

DT

EAD

ECR

EBE

EEUSP

ESF

G

HIPERDIA

IES

INCA

MS

NANDA
Associação Americana de Musicoterapia

Análise de Variância

Concordo mais que discordo

Concordo Parcialmente

Concordo Totalmente

Conselho Nacional de Saúde

Conselho Federal de Enfermagem

Comunicação Musical Editora e Produtora

Ré maior

Discordo mais que concordo

Descritores em Ciências da Saúde

Discordo Parcialmente

Discordo Totalmente

Educação à distância

Ensaio Clínico Randomizado

Escala de Bem-Estar Espiritual

Escola de Enfermagem da USP

Estratégia Saúde da Família

Sol maior

Sistema de Cadastramento de Hipertensos e Diabéticos

Instituição de Ensino Superior

Instituto Nacional de Câncer

Ministério da Saúde

North American Nursing Diagnosis Association 
NEPAAF

NIC

NOC

OMS

PNAO

PNPIC

PR

PROESA

RFCC

SPSS

SUS

TCLE

TFD

TLP

UCLA

UEM

UNICESUMAR

UNISANTA

USP

VD

VI
Núcleo de Estudos, Pesquisa, Assistência e Apoio à Família

Nursing Interventions Classification

Nursing Outcomes Classification

Organização Mundial de Saúde

Política Nacional de Atenção Oncológica

Política Nacional de Práticas Integrativas e Complementares

Paraná

Programa de Pós-Graduação em Enfermagem na Saúde do Adulto

Rede Feminina de Combate ao Câncer

Statistical Package for the Social Sciences

Sistema Único de Saúde

Termo de Consentimento Livre e Esclarecido

Tratamento Fora do Domicílio

Transtorno do Luto Prolongado

University of California at Los Angeles

Universidade Estadual de Maringá

Centro Universitário de Maringá

Universidade Santa Cecília

Universidade de São Paulo

Variável Dependente

Variável Independente 


\section{SUMÁRIO}

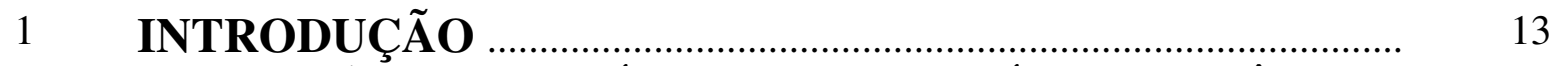

1.1 A RELAÇÃO COM A MÚSICA E A TRAJETÓRIA ACADÊMICA 14

1.2 O PROBLEMA DE PESQUISA …………………………………........ 18

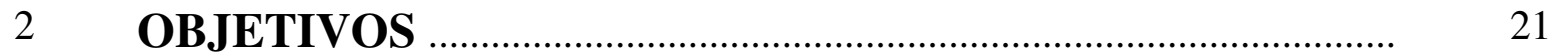

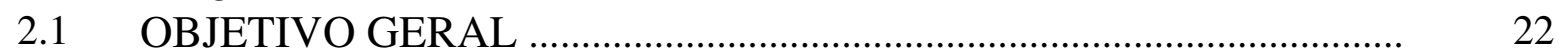

2.2 OBJETIVOS ESPECÍFICOS ……………………………………....... 22

$3 \quad$ REFERENCIAL TEÓRICO …………………………………........ 23

3.1 CUIDADOS PALIATIVOS _................................................................ 24

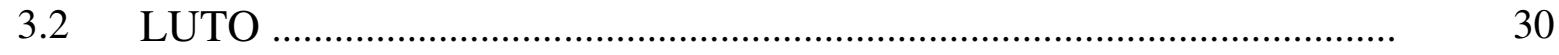

3.3 ESPIRITUALIDADE E RELIGIOSIDADE ...................................... 41

3.4 A MUSICOTERAPIA COMO RECURSO DE CUIDADO ................... 48

3.5 TEORIAS DE ENFERMAGEM E CUIDADOS PALIATIVOS ........... 59

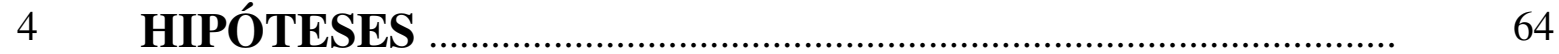

$5 \quad$ MÉTODO

5.1 TIPO DE ESTUDO _.......................................................................... 67

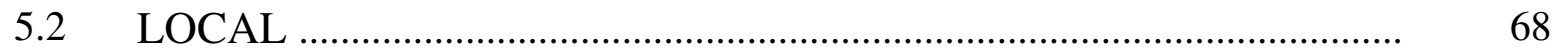

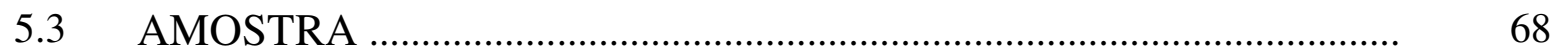

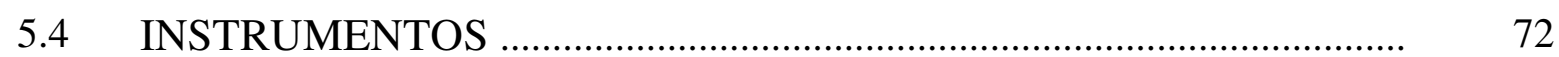

5.4.1 Formulário semiestruturado .......................................................................

5.4.2 Escala de Bem-Estar Espiritual (EBE) ………………………………….....

5.5 PROCEDIMENTOS DE COLETA DE DADOS ……............................ 73

5.6 DIRETRIZES PARA RELATÓRIOS DE INTERVENÇÕES MUSICAIS .. $\quad 75$

$5.7 \quad$ TRATAMENTO DOS DADOS ……………………................................ 79

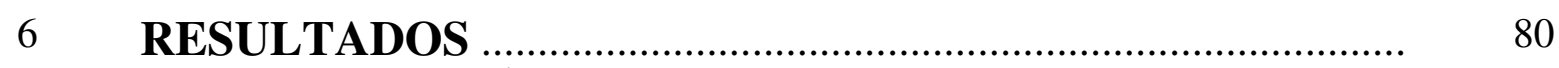

6.1 CARACTERIZAÇÃO DA AMOSTRA …...........................................

6.2 NÍVEIS DE BEM-ESTAR ESPIRITUAL ……................................... 89

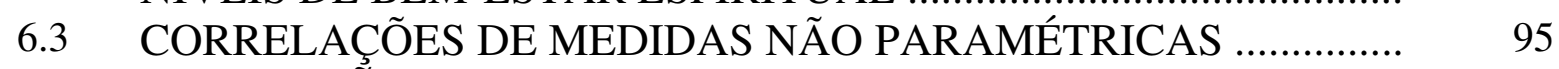

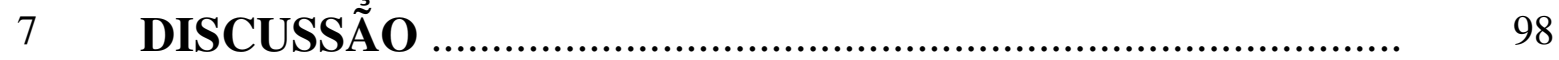

7.1 LIMITAÇÕES DO ESTUDO ……………..................................... 110

7.2 CONTRIBUIÇÕES PARA O AVANÇO DA CIÊNCIA E ARTE DA ENFERMAGEM …………………………………………………….... 110

$8 \quad$ CONCLUSÃO

9 CONSIDERAÇÕES FINAIS …………………………………….... 115

REFERÊNCIAS ……………………………………………….... 117

APÊNDICES ………………………………………………..... 134

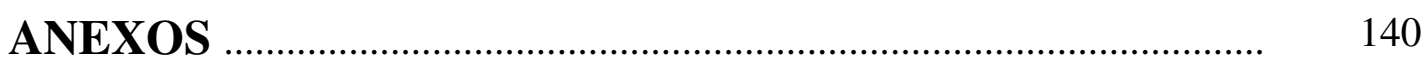


É impossível conhecer o homem sem lhe estudar a morte, porque, talvez mais do que na vida, é na morte que o homem se revela. É nas suas atitudes e crenças perante a morte que o homem exprime o que a vida tem de mais fundamental.

Edgar Morin 


\section{INTRODUÇÃO}

\subsection{A RELAÇÃO COM A MÚSICA E A TRAJETÓRIA ACADÊMICA}

A minha relação com a música, provavelmente, iniciou-se durante a vida intrauterina, quando, além de ser acompanhado pelo som e ritmo do coração de minha mãe, um evento inerente à fisiologia e o desenvolvimento humano, era envolvido por sua voz suave quando cantava. E assim fui crescendo, ouvindo este som familiar, nas missas, encontros de casais e serenatas. Acredito que seja um dom de Deus, congênito e hereditário, algo que corre nas veias. Afinal, como explicar uma família de músicos sem formação musical?

Meu avô materno, músico autodidata, aprendeu a tocar acordeão, violão e bateria. Minha mãe é musicista e compositora inata, canta e toca uns poucos acordes no violão. Meu pai fez um curso básico de violão depois de casado, e desde então a acompanha nos compromissos que envolvem o Ministério da Música na Igreja Católica. Dos três filhos que tiveram, todos manifestaram certa "inteligência musical" e mesmo sem formação técnica ou acadêmica, tiveram experiência como músicos de banda de baile. Desde criança sempre estivemos envolvidos no ministério supracitado.

Todavia, costumo dizer que não toco nenhum instrumento, apenas tiro som deles violão, piano e saxofone - pois, a meu ver, tocar um instrumento exige muita dedicação e técnica, o que não é o caso. Sei apenas o suficiente para satisfazer o meu prazer, me divertir com os meus amigos, ou promover conforto e bem-estar aos meus pacientes. Sou formado em teoria musical pelo Conservatório Musical Santa Cecília de Astorga, Estado do Paraná (PR), e concluí, informalmente, um método de saxofone. Não tive aula de violão e os quatro meses de aula de piano, foram cursados quando eu já integrava uma banda como tecladista. Assim como minha mãe, também me atrevo a compor e, durante a graduação não foi diferente.

Em 2005 ingressei o curso de Enfermagem no Centro Universitário de Maringá (UNICESUMAR) e durante a disciplina "Enfermagem como profissão" compus a música Florence Nightingale, que aborda a história de vida da precursora da Enfermagem moderna. No projeto de extensão universitária "Cogitare" direcionado aos usuários da Casa de Apoio da Rede Feminina de Combate ao Câncer (RFCC) de Maringá, iniciei o que considero minha experiência clínica, pois inseri a música como recurso de cuidado ao paciente oncológico, objetivando o seu bem-estar e sua qualidade de vida, mas sem caráter investigativo. Contudo, 
os resultados observados despertaram-me o interesse em estudar a utilização da música no cuidado de Enfermagem. Neste período também compus uma música que foi considerada a trilha sonora do referido projeto: Um mundo melhor (2006).

Com o intuito de abordar a Hipertensão Arterial de uma forma criativa, compus Cuidar do nosso coração (2006), que foi apresentada durante uma reunião de usuários hipertensos e diabéticos do Sistema de cadastramento e acompanhamento de hipertensos e diabéticos (HIPERDIA), realizado em uma Unidade Básica de Saúde onde estagiei. Em outro projeto de extensão universitária "A música e o envelhecimento", implementado em três Instituições de Longa Permanência, a música subsidiaria interação social e o resgate de reminiscências em idosos, dissipando a monotonia e o déficit de lazer subsistente.

Para a disciplina "Enfermagem em Saúde da Criança e do Adolescente" (2007) compus paródias das canções de roda "Atirei o pau no gato", "Ciranda cirandinha" e "Marcha soldado", abordando dermatite de fraldas, pediculose e intoxicação infantil, respectivamente. Emergentes do contexto sociocultural da criança, essas melodias constituíram um recurso em comunicação adequado à sua capacidade de compreensão, capaz de despertar interesse e atenção, e auxiliar no processo ensino-aprendizagem. Trilha sonora de uma peça de teatro infantil inédita, as paródias foram apresentadas em Centros de Educação Infantil e Escolas de Ensino Fundamental. Durante o "Estágio Supervisionado na Atenção Integral" (2008) reutilizei a estratégia de cuidado, ratificando o sucesso outrora evidenciado.

Luz do cuidar (2008), a meu ver a mais bela das minhas composições, foi idealizada para homenagear os colegas do terceiro ano do curso durante a Cerimônia da Lâmpada, onde os graduandos entregam aos seus sucessores a lâmpada - símbolo da Enfermagem representando a sucessão do conhecimento. Entretanto, por motivos profissionais não pude participar da cerimônia, mas a música foi interpretada durante o culto ecumênico em comemoração e ação de graças pela formatura da minha turma, emocionando muitos colegas e convidados. Assim, a música se fez presente ao longo da graduação, manifestando-se por meio de composições inéditas e paródias, constituindo recursos didáticos criativos e efetivos no processo ensino-aprendizagem e de comunicação, na prevenção e promoção da saúde.

No ano de 2009 cursei três disciplinas do Programa de Pós-Graduação Mestrado em Enfermagem da Universidade Estadual de Maringá (UEM) como aluno não regular, e integrei o projeto de extensão universitária "Cuidados paliativos a pessoas com câncer e suas famílias", onde realizava visitas musicais nas residências das famílias assistidas, aprimorando sua qualidade de vida ao aliviar a angústia relacionada à iminência de morte. Este projeto foi cenário de estudo da minha primeira publicação científica, intitulada "A música na 
terminalidade humana: concepções dos familiares"1, vinculada ao Núcleo de Estudos, Pesquisa, Assistência e Apoio à Família (NEPAAF) da UEM.

O conhecimento adquirido na disciplina "Cuidado paliativo ao doente terminal e sua família" despertou-me o interesse por cuidados paliativos e a idealização de associar música à filosofia paliativista. Deste modo, iniciei minha trajetória de aperfeiçoamento nesta área participando do III Encontro de Bioética de Londrina, II Jornada Paranaense de Cuidados Paliativos, Fórum Paranaense de discussão da Resolução No 240 do Conselho Nacional de Saúde (CNS), I Encontro do Capítulo Paranaense da Academia Nacional de Cuidados Paliativos, em Londrina (2009) e do III Curso Básico de Cuidados Paliativos, promovido pelo Instituto Palliare de Cuidados Paliativos de Londrina (2010).

Oficialmente, ingressei no mestrado em 2010 e minha dissertação, intitulada "Encontros musicais como recurso no cuidado de enfermagem em cuidados paliativos oncológicos: uma análise fenomenológica"2 constitui um estudo qualitativo fenomenológico, estruturado na analítica existencial de Martin Heidegger, que objetivou desvelar a percepção dos usuários (pacientes e familiares) da casa de apoio da RFCC de Maringá, em relação aos encontros musicais.

As publicações extraídas do estudo supracitado - "Encontros musicais como recurso em cuidados paliativos oncológicos a usuários de casas de apoio"3; "Percepções de familiares de pessoas portadoras de câncer sobre encontros musicais durante o tratamento antineoplásico"4; "Significados e sentidos da identidade musical de pacientes e familiares sob cuidados paliativos oncológicos" $" 5$ - evidenciam que os encontros musicais podem inspirar vida aos dias dos pacientes, imprimindo-lhes a sensação de cuidado e resignificando sua existênica ${ }^{3}$; subsidiar conforto aos familiares, introspecção e expressão de subjetividades, suportando sua transcendência existencial ${ }^{4}$; e que os significados e sentidos de sua identidade musical estão atrelados à sua espiritualidade e aos eventos significativos de sua historicidade ${ }^{5}$.

Assim, a supereminência da música intermediou a copresença entre os usuários, viabilizando a interação social, o entretenimento e o compartilhar de experiências, expectativas e estratégias de enfrentamento, isto é, a possibilidade de estar com o outro em sua temporalidade existencial - existir no mundo com câncer ou coexistir no mundo com ele. Nesse ínterim, vivenciei a concretização da minha intenção paliativista de humanizar o cuidado de Enfermagem, confortar, aliviar a dor e o sofrimento de pacientes oncológicos e suas famílias, contribuindo para a sua qualidade de vida² .

Concomitantemente ao mestrado, em 2011 iniciei o curso de Pós-graduação Lato Sensu em Cuidados Paliativos (Educação à Distância - EAD) pelo Instituto de Saúde e 
Educação Pinus Longaeva de São Paulo, em parceria com a Universidade Santa Cecília (UNISANTA), que subsidiou recursos imprescindíveis para a compreensão desta filosofia de cuidados. Neste ano, atuei como enfermeiro assistencial em uma Unidade Coronariana, onde cantava para os pacientes enquanto realizava os procedimentos técnicos, com o intuito de reduzir os níveis de estresse, ansiedade e depressão inerentes à hospitalização.

Buscando aprimoramento nesta linha investigativa, em 2012 integrei o Grupo de Pesquisa Estudo das Práticas Alternativas ou Complementares de Saúde da Escola de Enfermagem da Universidade de São Paulo (EEUSP), onde foi possível ampliar o meu conhecimento acerca da temática, inclusive sobre musicoterapia. Em 2013 ingressei no doutorado, pelo Programa de Pós-Graduação em Enfermagem na Saúde do Adulto (PROESA) da EEUSP, e integrei o Grupo de Estudo e Pesquisa sobre Comunicação em Enfermagem, que muito contribuiu no desenvolvimento de habilidades comunicativas, indispensáveis neste contexto de cuidado.

No decorrer do doutorado, elaborei uma revisão integrativa intitulada "Avaliação da qualidade de evidências científicas sobre intervenções musicais na assistência a pacientes com câncer", ${ }^{\prime \prime}$ cujo resumo, intitulado Avaliação da qualidade metodológica dos relatórios de intervenções musicais na assistência a pacientes com câncer ${ }^{7}$, foi apresentado em setembro de 2014, em Cartagena de Índias - Colômbia, e publicado nos Anais do XIV Coloquio Panamericano de Investigación em Enfermemría. Os resultados do estudo supracitado evidenciaram descrições insuficientes acerca dos recursos e estruturas musicais utilizados nas intervenções, demonstrando a complexidade da estratégia "música" enquanto recurso terapêutico, e a banalização do seu potencial terapêutico, limitando sua replicação e incorporação das evidências na prática clínica ${ }^{6}$.

Em maio de 2015, os resultados parciais desta tese também foram apresentados e publicados com o título Sacred music and spiritual well-being of bereaved family: a randomized clinical Trial ${ }^{8}$, nos Anais do 14th World Congress of the European Association for Palliative Care, em Copenhague - Dinamarca, efetivando o compromisso de internacionalização do conhecimento, firmado com o PROESA.

Empiricamente, tenho observado há algum tempo, no universo de minhas experiências pessoais, familiares e religiosas, mais especificamente observando o valioso trabalho da Pastoral da Esperança em rituais fúnebres, o quanto a música sacra cantada pode confortar os familiares enlutados. A Pastoral da Esperança, um dos movimentos da Igreja Católica, acompanha a família enlutada em seu processo de elaboração do luto, por meio de orações e reflexões. 
Para isso, dispõe de um manual intitulado Na Casa do Pai: encontros para exéquias, velório, sepultamento e missa ${ }^{9}$, que contém três vigílias realizadas durante o funeral, uma oração de despedida, antes da benção do corpo pelo sacerdote, e uma oração final que acontece no momento do sepultamento com a benção do túmulo. O manual contém, ainda, sete encontros diários que são realizados na casa do familiar enlutado, para os quais são convidados familiares e amigos. Todas as vigílias e encontros são estruturados com orações, leituras bíblicas, reflexões e música sacra.

Muitos e gratificantes são os testemunhos ouvidos, sobretudo no último dia dos sete encontros. Nesse período, ainda é realizada a missa de sétimo dia e se a família aceitar, a celebração da esperança, quando completar um mês de morte. Assim, a Pastoral da Esperança tem sido luz para as famílias enlutadas, levando a presença da Igreja que acolhe, anima, abraça e consola no momento mais crucial da existência humana - a morte de um ente querido, o vazio de sua ausência, a saudade e o abismo que os separam - onde somente a oração e a solidariedade fraterna podem amenizar os lamentos que emanam do coração.

O contato com este cenário despertou-me o desejo de investigar sobre a influência da música sacra no processo de elaboração do luto, e, consequentemente, a formular os objetivos e as hipóteses do presente estudo.

\subsection{O PROBLEMA DE PESQUISA}

Os indicadores de mortalidade e de natalidade sugerem o aumento da longevidade e o envelhecimento populacional, resultando em maior incidência e prevalência de doenças crônico-degenerativas como as cardiovasculares e o câncer ${ }^{10}$. De acordo com o Instituto Nacional de Câncer (INCA), a estimativa da incidência de câncer no Brasil para o biênio 2014/2015 é de aproximadamente 576.580 casos novos. No âmbito mundial, a Organização Mundial de Saúde (OMS) aponta a ocorrência de 21,4 milhões de casos novos em 2030 e 13,2 milhões de mortes ${ }^{11}$.

Diante do panorama epidemiológico emergente no Brasil, a Política Nacional de Atenção Oncológica (PNAO), instituída pela Portaria 2.439, de 8 de dezembro de 2005, reconhece o câncer como problema de saúde pública ${ }^{12}$. Em 3 de setembro de 2009, a Portaria 2.048 consolida a PNAO, dispondo desde medidas profiláticas à assistência de alta complexidade - promoção, prevenção, diagnóstico, tratamento, reabilitação e cuidados paliativos - para redução da incidência e da mortalidade por câncer, bem como para subsidiar qualidade de vida aos doentes e familiares ${ }^{13}$. 
Não obstante, mais de um milhão de brasileiros morrem por ano e, em sua maioria, desprovidos de assistência física, psicológica, social e espiritual adequada. Em geral, o cuidado aos familiares é inexistente, pois os profissionais da área da saúde não tiveram formação para lidar com as necessidades emergentes no convívio com doenças avançadas e incuráveis, tampouco lidar com a morte e o processo de luto ${ }^{14}$. Deste modo, insurge a necessidade de reconhecer que a essência dos cuidados paliativos se alicerça no alívio do sofrimento ${ }^{15}$, contemplando as necessidades multidimensionais de pacientes e familiares.

Nesse contexto, estruturadas nos pressupostos filosóficos dos cuidados paliativos, surgem inúmeras iniciativas como a utilização da música como recurso de cuidado, por sua contribuição multidimensional, sobretudo por possibilitar um lugar de trocas - afetos, emoções, delicadezas - a expressão de afetividade, muitas vezes despercebida no processo de cuidar, transcendendo o cuidado fragmentado e desumano ${ }^{16}$.

Embora a filosofia paliativista esteja bem estruturada, a produção de conhecimento na área encontra-se em fase de expansão e consolidação. As pesquisas concentram-se na dinâmica dos processos de morte e morrer, luto e comunicação, nos aspectos emocionais e nos princípios legais e bioéticos. Contudo, ainda existem lacunas concernentes à compreensão do significado de angústia espiritual, da influência da espiritualidade e religiosidade nas situações de luto e morte, e de estratégias para aliviar o sofrimento espiritual, melhorar o acolhimento e a comunicação ${ }^{17}$.

Ressalta-se que as intervenções realizadas por enfermeiros no cuidado à família enlutada ainda nos são incipientes, mas essas experiências têm despertado o interesse de pesquisadores. Enfatiza-se que o cuidado nestas condições exige relacionamentos sofisticados e de difícil articulação, onde é preciso ajudar os familiares enlutados "a perceber que, às vezes, o que mais pode lhes dar conforto é, ironicamente, do que estão fugindo - falar sobre sua perda",18:VIII.

No entanto, é necessário compreender e aceitar que o outro é um ser permeado de crenças e valores, e que a espiritualidade, religiosidade ou crenças religiosas ajudam a dar significado às experiências de doença e de morte; proveem suporte social, emocional e espiritual - conforto, consolo, motivação e esperança - renovando as energias e direcionando o comportamento dos familiares durante o seu estado de adaptação à doença e morte ${ }^{19}$.

Seguindo este pensar, o cuidado de Enfermagem aos familiares enlutados precisa ser compartilhado, confluindo com o conhecimento de outras disciplinas, objetivando a interdisciplinaridade e a construção de uma abordagem qualificada para assisti- $\operatorname{los}^{20}$ no momento de relação com a morte e o luto. Nesse ínterim, a música insurge como uma 
intervenção de saúde que ultrapassa o domínio dos sintomas e das emoções, possibilitando a aproximação dos seres, o encontro do homem com sua própria essência, subsidiando a compreensão do sentido da vida, na unicidade e subjetividade de uma experiência que integra todas as dimensões humanas ${ }^{21}$.

Vislumbrando um alinhamento às propostas holísticas emergentes, a Enfermagem ainda reconhece na arte, o caminho para compreender a dimensão espiritual do cuidado, uma possibilidade latente em favor da saúde ${ }^{21}$. Nesse sentido, a música viabiliza a expressão da espiritualidade, proporcionando conforto, além de direcionar questionamentos e reflexões acerca do significado da vida e sua finitude ${ }^{22}$.

Vale destacar a dificuldade inerente à implementação de cuidados paliativos, decorrente da indisponibilidade de outros profissionais da área da saúde, por desconhecimento, resistência, insegurança ou preconceito em relação à filosofia paliativista no Brasil. Em contrapartida, a Enfermagem tem se empenhado, muitas vezes isoladamente, em atuar neste contexto que envolve, impreterivelmente, morte e espiritualidade.

A ideia de utilizar a musicoterapia para cuidar de familiares enlutados surgiu a partir dos resultados dos encontros musicais retromencionados ${ }^{4}$, onde foi possível apreender que a música sacra pode representar um "remédio para o sofrimento", um "alimento espiritual" que evoca a presença de Deus, aliviando a dor e a angústia de presenciar, de modo impotente, o processo de morte e morrer de um ente querido com câncer.

Além disso, embora a musicoterapia seja a abordagem criativa mais investigada e documentada como suporte para pessoas enlutadas, indicada como adjuvante no aconselhamento de luto ou parte integrante do processo terapêutico, evidencia-se a escassez de estudos realizados com adultos enlutados ${ }^{23}$, de musicoterapia realizada por enfermeiros, de estudos que avaliem os efeitos da musicoterapia no bem-estar espiritual, sobretudo utilizando música sacra, no contexto dos cuidados paliativos e com delineamento experimental.

Destarte, idealizou-se como Tese utilizar a musicoterapia como recurso complementar no cuidado paliativo de Enfermagem a familiares enlutados, ponderando que a morte de um ente querido constitui uma perda significativa que traz consigo a necessidade de um ajustamento social, haja vista que os sentimentos que a acompanham são profundos, intensos e multifacetados, afetando emoções, corpos e vidas, por um longo período de tempo ${ }^{24}$. Diante do exposto, questiona-se: a musicoterapia influencia o bem-estar espiritual de familiares enlutados? 
Já tive medo de morrer. Não tenho mais. Tenho tristeza. A vida é muito boa. Mas, a morte é minha companheira. Sempre conversamos e aprendo com ela. Quem não se torna sábio ouvindo o que a morte tem a dizer está condenado a ser tolo a vida inteira.

Rubem Alves 


\section{OBJETIVOS}

\subsection{OBJETIVO GERAL}

Avaliar os efeitos da musicoterapia no bem-estar espiritual de familiares enlutados.

\subsection{OBJETIVOS ESPECÍFICOS}

- Caracterizar a amostra quanto às variáveis sociodemográficas, as relacionadas à crença religiosa, às experiências sonoro-musicais e aos fatores intervenientes no processo de elaboração do luto.

- Identificar os níveis de bem-estar espiritual dos participantes antes e depois da intervenção.

- Comparar os níveis de bem-estar espiritual entre os grupos experimentais e o grupo controle.

- Descrever os sentimentos evidenciados pelos participantes após a intervenção.

- Descrever a apreciação estética dos participantes em relação às musicas que ouviram.

- Verificar as correlações entre os escores de bem-estar espiritual e as variáveis sociodemográficas, as relacionadas à crença religiosa, às experiências sonoro-musicais, aos fatores intervenientes no processo de elaboração do luto, aos sentimentos evidenciados e à apreciação estética após a intervenção. 
Música é esperança. Esperança diminui a dor. A música é a palavra de Deus; a conexão com o universo. Música é a esperança sem dor. José Luiz Tejon 


\section{REFERENCIAL TEÓRICO}

\subsection{CUIDADOS PALIATIVOS}

Etimologicamente, a expressão "paliativo" deriva do latim, pallium, que significa "manto" e traz em si a essência desta filosofia de cuidado - proteger, amparar, envolver e abrigar pessoas com doenças incuráveis. Deste modo, transcende o controle de sintomas, oferecendo um cuidado holístico, que não considera apenas a doença, mas todas as dimensões humanas ${ }^{15}$.

Contudo, o conceito de cuidados paliativos teve origem no movimento hospice ${ }^{25}$, termo usualmente empregado para referenciar as casas de doentes da Idade Média, que designava os locais que ofereciam descanso e cuidados para viajantes e cruzados em suas peregrinações ${ }^{26}$. Este termo, também de origem latina hospitium, significa hospedagem, hospitalidade. Hospitium, por sua vez, significava tanto o local, como o vínculo estabelecido entre as pessoas ${ }^{27}$.

Atualmente, hospice é utilizado para denotar a filosofia do cuidado integral e interdisciplinar ao paciente com doença incurável, desde o diagnóstico até a morte, e hospedaria designa um dos ambientes físicos onde este cuidado, denominado cuidado paliativo, é oferecido ao doente e sua família ${ }^{28}$. Ressalta-se que os raros estudos históricos sobre os hospices britânicos da época enfatizam a intensa orientação religiosa nos cuidados espirituais e a expressiva presença da Enfermagem nos cuidados físicos, como alicerces do moderno movimento hospice ${ }^{29}$.

Com efeito, a origem dos hospices data do século IV, quando Fabíola, matrona romana, visando praticar "obras da misericórdia cristã", disponibilizou sua casa, alimentos e roupas aos necessitados, acolhia estrangeiros e visitava enfermos e prisioneiros. Posteriormente a Igreja tomou para si o cuidado dos pobres e doentes, e os hospices abrigaram viajantes e peregrinos durante séculos ${ }^{15}$.

No início do século XIX, o cuidado no fim da vida foi liderado por três mulheres: Jeanne Garnier na França, Mary Aikenhead na Irlanda e Rose Hawthorne nos Estados Unidos $^{30}$. Jeanne Garnier instituiu em 1841 L'Association des Dames du Calvaire (a Associação das Damas do Calvário) em Lyon, e uma casa para pessoas no fim da vida em 1843, incitando a criação de outras instituições em Paris (1874) e Nova York (1899) ${ }^{31}$. 
Mary Aikenhead fundou o convento das Irmãs Irlandesas da Caridade e colaborou para a abertura do St. Vincent Hospital, em Dublin, em 1834. O convento que a acolheu no fim de sua vida transformou-se no Our lady's Hospice, em 1879. As Irmãs da Caridade fundaram outros hospices na Austrália, Escócia e o famoso St. Joseph's Hospice na Inglaterra, em 1907. Rose Hawthorne organizou um grupo de mulheres designadas Servants of Relief of Incurable Cancer (Servas do Alívio do Câncer Incurável), em 1890. Dez anos depois, constituiu a ordem das Irmãs Dominicanas de Hawthorne, o St. Rose's Hospice em Manhattan e hospices em outras regiões dos Estados Unidos ${ }^{31}$.

Decorrentes das transformações sucedidas na área da saúde durante o século XX, como o aumento de especializações, o surgimento de novos tratamentos, e uma progressiva ênfase na cura e na reabilitação, o cenário de despedida da vida, antes predominantemente familiar, desloca-se para o hospital e observa-se o crescente interesse pela eutanásia no Reino Unido e nos Estados Unidos ${ }^{30}$. Todavia, várias hospedarias surgiram na França, na Irlanda e na Inglaterra, mas destinadas a acolher pacientes em estágio terminal, ou seja, "viajantes apenas no sentido de que caminham pela estrada que liga esta vida à próxima"26:21 .

Entretanto, somente em 1967 que os hospices passaram a ser sinônimos de cuidados paliativos, em virtude da fundação do St. Christopher's Hospice na Inglaterra, idealizado por Cicely Saunders ${ }^{15}$. Vale lembrar que Saunders atuou como enfermeira e assistente social no St. Joseph's Hospice, mas para melhor cuidar dos pacientes em estágio terminal, esquecidos pelos médicos tradicionais, cursou Medicina tornando-se a primeira Doutora em cuidados paliativos $^{32}$. Comprometida com sua missão, “acreditou no cuidado diferenciado e por isso ousou e lutou contra as adversidades de seu tempo, mantendo sua essência de enfermeira em todas as suas ações" $33: 140$.

Nessa perspectiva, Saunders desenvolveu o conceito de "dor total", englobando além da dimensão física, a dimensão social, emocional e espiritual do sofrimento ${ }^{31}$. Posteriormente, a autora incorporaria ao conceito a dor financeira, a dor interpessoal e a dor da família. Salienta-se que, muitas vezes, “os doentes vivenciam não somente a dor causada pela doença, mas também a dor do isolamento, da discriminação social e indiferença das pessoas ao seu redor" $34: 122$.

Entender os conceitos por ela formulados é imprescindível para compreender as bases sobre as quais estão assentadas as colunas-mestras da filosofia hospice moderna ${ }^{14}$. Vislumbrando o ser humano de forma holística e a integralidade do cuidado, o St. Christopher's Hospice articula o alívio da dor e o controle de sintomas ao cuidado humanizado, o ensino e a pesquisa clínica, apresentando uma nova conduta em relação à 
morte, ao morrer e ao período de luto, edificando-se como referência mundial em termos de cuidado ${ }^{32}$.

Reverencia-se, também, a contribuição da psiquiatra Elisabeth Kübler-Ross, na disseminação do conceito de hospice proposto por Saunders, nos Estados Unidos ${ }^{14}$, sobretudo pela relevância do seu trabalho - Sobre a morte e o morrer - onde descreve os estágios psicológicos exacerbados no fim da vida: negação e isolamento, raiva, barganha, depressão e aceitação $^{35}$. Kübler-Ross também introduziu o estudo da tanatologia na área da saúde ${ }^{32}$.

Tradicionalmente, os cuidados paliativos estavam relacionados à iminência de morte, mas atualmente o mesmo deve ser utilizado desde o diagnóstico de doenças crônicodegenerativas, avançadas e incuráveis ${ }^{31}$. Nesse sentido, a Organização Mundial de Saúde OMS definiu os cuidados paliativos como:

O cuidado ativo total de pacientes cuja doença não responde mais ao tratamento curativo. Controle da dor e de outros sintomas e problemas de ordem psicológica, social e espiritual são prioritários. O objetivo dos cuidados paliativos é proporcionar a melhor qualidade de vida para os pacientes e seus familiares ${ }^{36}$.

Nesse período, os cuidados paliativos eram direcionados aos pacientes oncológicos e, gradativamente, estendeu-se às pessoas com doenças consideradas ameaçadoras de vida e à geriatria $^{33}$. Assim, em 2002, a OMS redefiniu este conceito enfatizando a qualidade de vida, a prevenção e o alívio do sofrimento em todas as suas dimensões:

\footnotetext{
Cuidados paliativos é uma abordagem que aprimora a qualidade de vida dos pacientes e famílias que enfrentam problemas associados com doenças ameaçadoras de vida, através da prevenção e alívio do sofrimento, por meios de identificação precoce, avaliação correta e tratamento da dor e outros problemas de ordem física, psicossocial e espiritual $^{37}$.
}

A partir desta definição, edificam-se os pressupostos filosóficos que regem esta abordagem: proporcionar alívio da dor e outros sintomas angustiantes; afirmar a vida e encarar a morte como um processo normal; não apressar ou adiar a morte; integrar os aspectos psicológicos e espirituais da assistência ao paciente; oferecer um sistema de apoio para ajudar os pacientes a viver tão ativamente quanto possível até a morte; oferecer um sistema de apoio para ajudar a família a lidar com a doença do paciente e seu próprio luto; usar uma abordagem em equipe para atender às necessidades de doentes e suas famílias, incluindo aconselhamento de luto, se indicado; melhorar a qualidade de vida, e também influenciar positivamente o curso da doença; ser aplicável no início do curso da doença, em conjunto com outras terapias 
que visam prolongar a vida, como a quimioterapia e radioterapia, e incluir as investigações necessárias para melhor compreender e gerenciar complicações clínicas angustiantes ${ }^{37}$.

Não obstante, na perspectiva organizativa, a prestação de cuidados paliativos pode ser dividida em quatro níveis: ações paliativas, cuidados paliativos gerais, cuidados paliativos especializados e centros de excelência. As ações paliativas reportam-se aos cuidados fundamentados nos pressupostos filosóficos dos cuidados paliativos, implementados em qualquer serviço não especializado, por qualquer profissional de saúde com formação básica em cuidados paliativos, no sentido de aliviar o sofrimento e controlar sintomas. Abrange medidas farmacológicas e não farmacológicas como a comunicação entre o doente, a família e os profissionais de saúde, o apoio à tomada de decisão e o respeito aos objetivos e preferências do doente ${ }^{38}$.

Os cuidados paliativos gerais compreendem os cuidados prestados por profissionais da atenção básica, ou especialistas em doenças ameaçadoras da vida, com competências e conhecimentos em cuidados paliativos, cujo principal foco de atuação não seja os cuidados paliativos. Os cuidados paliativos especializados abrangem os cuidados prestados por equipes interdisciplinares, altamente qualificadas, em serviços especializados em cuidados paliativos, direcionados para doentes com maiores níveis de complexidade. Os Centros de excelência constituem núcleos de formação, investigação, disseminação e desenvolvimento de padrões e inovações de técnicas de abordagem em cuidados paliativos, disponibilizando-os em um largo espectro de tipologias ${ }^{38}$.

Independentemente do nível de prestação de cuidados, o paciente e a família sob cuidados paliativos precisam ser assistidos na complexidade de suas necessidades ${ }^{39}$. Nesse contexto, o enfermeiro paliativista, enquanto sujeito cuidador, busca por meio do seu conhecimento amenizar ou suprimir quaisquer desconfortos que o paciente e/ou família expressem $^{40}$, demonstrar solicitude para com o outro, compadecer de sua dor e respeitar sua unicidade, sua temporalidade e sua percepção ${ }^{41}$.

No Brasil, a inserção desta filosofia de cuidados ocorreu no início da década de 1980, período marcado pelo fim da ditadura. O paradigma hospitalocêntrico - essencialmente curativo, voltado para os aspectos biológicos, com abordagem multiprofissional - que compunha o cenário da saúde brasileira naquela época, subsiste até os dias atuais. Todavia, o paciente e sua família já são abordados como uma unidade de cuidado, haja vista que o sofrimento proveniente da doença e iminência de morte de um ente querido abrange o cerne familiar. A família experiencia a necessidade de cuidado e suporte para amparar o doente em seu processo de finitude e permanecer emocionalmente saudável no processo de luto ${ }^{33}$. 
Ressalta-se que o "envolvimento da família com a doença precede o diagnóstico", assim como a crise dela decorrente. Nesta fase, denominada pré-diagnóstica, a família percebe ou interpreta sintomas como sendo de risco, une-se ou fragmenta-se diante da dificuldade emergente ao lidar com os mesmos, revelando os padrões e mecanismos de enfretamento a serem adotados no decorrer da doença. Porém, nesta fase há muita incerteza, ansiedade, e culpa associada aos medos. Vale lembrar que "o padrão protetor inibe a habilidade dos outros de oferecer apoio e causa frustração e ressentimento à família". O familiar se preocupa com os significados que ele e a pessoa doente atribuirão à doença. Pode haver alterações nos padrões de comunicação, relacionamento sexual e relações de poder ${ }^{42: 358}$.

No período de diagnóstico, o paciente e a família recebem informações sobre a doença e suas implicações. Todavia, a incerteza prevalece, haja vista que surgem novas situações, referentes ao tratamento, à evolução da doença e ao prognóstico. Alguns familiares hesitam em compartilhar a notícia do diagnóstico com outros familiares ou até mesmo com o próprio paciente, instalando-se a conspiração de silêncio, que embora possa expressar alguma lógica, dificulta a comunicação e o apoio da família, podendo incitar, posteriormente, sentimentos como raiva, ressentimento e culpa. Logo, é importante avaliar os motivos e as consequências dessas decisões ${ }^{42}$.

Nessa fase, os projetos familiares são ameaçados, devendo ser modificados ou adiados, em decorrência das responsabilidades emergentes, da pressão do tempo e do impacto financeiro. Pode surgir, ainda, a preocupação de que o estresse, proveniente da demanda inerente à doença, possa causar problemas de saúde a outros membros da família. Observa-se, nitidamente, uma crise familiar, caracterizada por incertezas e ansiedades intermitentes, que afetam o paciente e sua rede de suporte, especialmente sua família. Enfatiza-se que nesse momento a família passa a experienciar o luto antecipatório, em virtude das mudanças e perdas vivenciadas ${ }^{42}$. Evidencia-se que a atenção ao luto preconizada na filosofia dos cuidados paliativos, inicia-se neste momento.

Deste modo, o efeito do diagnóstico atinge todo o sistema familiar ${ }^{42}$, especialmente quando se trata de uma doença como o câncer, que traz em si o estigma sociocultural de doença incurável e a conotação de dor, sofrimento e morte ${ }^{43}$. Essa fase, denominada crônica, é caracterizada pela necessidade de cuidados e adaptação às condições inusitadas advindas da doença, concomitantemente com a necessidade de conservar padrões habituais, cotidianos e previsíveis. As mudanças provenientes de exacerbações e crises agudas são aceitas pelo paciente e pela família, porém a perda da identidade, construída antes da doença, é lamentada ${ }^{42}$. 
$\mathrm{Na}$ fase terminal, quando a pessoa doente não pode mais desempenhar os papéis ou funções que lhe foram atribuídos pela dinâmica familiar, o equilíbrio da família sofre alterações importantes. Nessa fase, os familiares constatam que seu ente querido está morrendo, assim como sua família como existia até então. Destaca-se que o equilíbrio da família é afetado a partir do diagnóstico, porém de modo mais intenso quando a morte do paciente se aproxima ${ }^{42}$.

Com efeito, o estudo de revisão sobre cuidados paliativos e família, concluiu que os cuidados paliativos domiciliares trazem muitas implicações físicas e psicológicas para a família, haja vista que a sobrecarga do cuidado restringe as atividades dos familiares, suscitando preocupações, inseguranças, isolamento, cansaço e estresse, diante da iminência de morte e da ausência de suporte emocional e prático para a implementação deste cuidado. Assim sendo, embora reconheçam a importância de permanecerem juntos neste momento, pacientes e familiares ainda elegem as instituições de saúde como o melhor lugar para os últimos dias de vida ${ }^{44}$.

Entretanto, diante da falência do tratamento ativo da doença e da aproximação da morte inexorável do paciente, "o hospital raramente está preparado para tratar e cuidar de seu sofrimento e o de seus familiares", pois aprender a lidar com as perdas, é um desafio que poucos se atrevem a discutir, tampouco enfrentar, dificultando $\mathrm{o}$ tratamento $\mathrm{e} o$ acompanhamento integral dos pacientes com sofrimento intenso no fim da vida. Em contrapartida, os cuidados paliativos oferecem ao paciente que está morrendo, proteção contra o sofrimento evitável, salvaguardando sua dignidade como ser humano até os seus últimos momentos ${ }^{45: 8}$.

No que tange aos critérios de qualidade para os cuidados paliativos, o alívio do sofrimento, é referenciado como um direito do paciente, haja vista que

\footnotetext{
nenhum ser humano pode morrer em condição de sofrimento insuportável, seja ele de natureza física, psicológica ou espiritual. A terapêutica de alívio de sintomas e todas as demais medidas precisam ser administradas em nível de excelência, em todos os momentos e em particular nos últimos dias de vida, prevenindo situações de extremada agonia para o doente e seus familiares ${ }^{45: 15}$.
}

Ressalta-se que os "sintomas que causam qualquer tipo de sofrimento influenciarão a qualidade de vida e o tipo de morte que a pessoa terá". Deste modo, se o processo de morte e morrer ocorrer com dignidade, sem sofrimento para o paciente, certamente a família experienciará conforto ${ }^{45: 33}$ e enfrentará, com serenidade, o processo de elaboração do luto. Logo, dentre os desafios que direcionam a reflexão e disponibilização de melhores condições 
ao doente e à família sob cuidados paliativos, evidenciam-se a discussão sobre o tema morte e o morrer, a adequação da postura dos profissionais de saúde diante deste contexto, e o suporte para família no luto ${ }^{38}$.

\subsection{LUTO}

Dentre as experiências humanas, nenhuma é mais significativa em suas implicações do que a morte ${ }^{46}$. Ela nos remete a uma reflexão acerca da questão mais fundamental, intrigante, desafiadora e angustiante para a humanidade: a da sobrevivência pós-morte. Indubitavelmente a negamos, marginalizando sua presença em nossas vidas, mesmo que absorvidos pelos seus mistérios. Trata-se de um evento que transcende a dimensão biológica, abrangendo as dimensões religiosa, social, filosófica, antropológica, espiritual e pedagógica. Os questionamentos acerca do seu significado acompanham a evolução de todas as culturas desde tempos imemoriais ${ }^{47}$.

Assim, a morte de um ente querido representa não somente uma perda, mas uma aproximação da própria morte. A tristeza inerente a esta perda é preocupante e esgotante, e caracteriza-se pela exacerbação de sentimentos como angústia, raiva, arrependimento, saudade, medo e ausência ${ }^{24}$. Na concepção de Freud, o luto é a reação consciente à perda de um ente querido ou de uma abstração que o represente, delineada por estado de ânimo intensamente doloroso, desinteresse pelo mundo externo, incapacidade de substituir o objeto perdido, e afastamento de atividades não relacionadas à memória do morto ${ }^{48}$; e tem como função primordial, desligar dos mortos, as lembranças e esperanças das pessoas enlutadas ${ }^{49}$.

Vale lembrar que, embora tenha sido muito criticado, o modelo de elaboração do luto apresentado por Freud - Luto como reação à perda de um objeto libidinal - tornou-se pilar referencial na construção de outras teorias que abordam essa temática ${ }^{50}$ - Teoria das Relações Objetais $^{51}$; Teoria dos fenômenos e objetos transicionais ${ }^{52}$; e Teoria do Apego ${ }^{53}$. Ressalta-se que o conceito de "trabalho de luto" concebido por Freud, constitui um processo elaborativo intrínseco à pessoa enlutada, que demanda energia psíquica e pode ou não ser bem sucedido ${ }^{54}$.

Com efeito, esse conceito inovou a compreensão do enlutamento, outrora percebido, principalmente pelo senso comum, como uma atenuação espontânea e progressiva da dor proveniente da perda de um ente querido ${ }^{54}$. Nesse sentido, a pessoa enlutada precisa adaptarse à perda, confrontando sua realidade existencial e a percepção de que o mundo tornou-se pobre e vazio ${ }^{50}$. 
No que tange à Teoria das Relações Objetais, idealizada por Klein ${ }^{51}$, o desligamento do objeto externo perdido não implica no abandono da relação com o objeto interno, mas na sua transformação por meio da experiência de perda. Deste modo, torna-se imprescindível que a pessoa enlutada confie em sua capacidade de reorganizar-se internamente.

Concernente à Teoria dos fenômenos e objetos transicionais, desenvolvida por Winnicott ${ }^{52}$, o "trabalho de luto" objetiva conservar reminiscências vivas do objeto perdido, impedindo que a pessoa enlutada resignifique apenas a realidade - o vazio experienciado, que desperta um estado de desamparo - sem, contudo, evoluir para um processo alucinatório, negando a perda. A elaboração da perda ocorre, portanto, no espaço da ilusão, onde é possível reencontrar, de certo modo, o que foi perdido ${ }^{55}$. Essa teoria contribui para a compreensão teórica da necessidade de manutenção do vínculo com o objeto perdido ${ }^{50}$.

Ressalta-se que o comportamento do vínculo significa sobrevivência em todas as espécies, e o luto, traduzido como aspecto negativo do vínculo, constitui uma reação comum ante a separação. A qualidade do vínculo delimitada a priori, influencia os vínculos subsequentes e subsidia os recursos necessários para enfrentar e elaborar rupturas e perdas. Logo, um vínculo seguro propicia a ampliação da autoconfiança e da autoestima ${ }^{24}$.

Nesse sentido, o impacto da perda pode diminuir ante o estabelecimento de vínculos substitutos, representando o acolhimento da função de suporte social. Assim, é necessário avaliar as condições que antecederam a perda por morte. No contexto individual consideramse as experiências pregressas envolvendo perdas e a qualidade do que foi perdido, bem como os recursos psíquicos disponíveis para a sua elaboração. No plano social, enfatiza-se a disponibilidade de uma rede de suporte e a possibilidade do indivíduo absorvê-la como aceitável e útil ${ }^{24}$.

O apoio afetivo e social nunca será excessivamente valorizado nessas circunstâncias, e o enlutado pode buscar a companhia de amigos empáticos, ou mesmo buscar novos relacionamentos, sobretudo no caso daqueles que se encontram afastados de suas fontes de satisfação e reconhecimento afetivo ${ }^{56: 251}$.

Seguindo este pensar, evidencia-se a importância das redes sociais virtuais, como o Facebook $^{57}$, que estimulam a expressão de sentimentos e sofrimentos, geralmente retraídos, por envolver temas dificilmente discutidos abertamente, como a morte e o morrer; a notificação de morte; a conexão e comunicação com a pessoa que morreu; a divulgação de rituais, homenagens póstumas e agradecimentos; a expressão de condolências aos familiares enlutados; e, consequentemente, a interação e o suporte social, favorecendo o processo de 
elaboração do luto de pacientes, familiares e profissionais que encaram o fim da vida e o luto 58 .

$\mathrm{Na}$ Teoria do Apego, Bowlby ${ }^{59}$ conceitua o luto como uma reação ao rompimento de vínculos afetivos, articulando conhecimentos da Psicanálise e da Etologia, tendo como objeto de estudo, os vínculos afetivos estabelecidos entre seres humanos, bem como as reações e os transtornos de personalidade decorrentes de situações que envolvem rompimentos e perdas involuntários.

O apego constitui um importante organizador do significado ${ }^{60,61}$, que emerge na relação das dimensões psicológica, biológica, social e cultural, e influencia a relação do ser humano consigo mesmo e com o mundo (o outro, a sociedade, Deus, os valores e as crenças) ${ }^{50}$. Destaca-se que uma das mais importantes funções da figura de apego é subsidiar uma base segura que possibilite ao indivíduo a exploração do meio. Perder uma figura de apego implica em perder, também, essa base segura, tornando a experiência ameaçadora e despertando ansiedade de separação ${ }^{53,62}$.

Nesse contexto, o processo de elaboração do luto pode ser subdivido em quatro fases:

- torpor ou aturdimento: manifestado diante da notícia da perda, quando a pessoa enlutada experiencia uma sensação de entorpecimento. No entanto, para evitar o contato com a realidade de difícil aceitação, a pessoa enlutada utiliza o mecanismo de defesa de negação. De forma consciente e deliberada, os sentimentos também podem ser evitados. Esta fase pode durar horas ou dias ${ }^{53,59}$.

- saudade e busca da figura perdida: concomitante ao processo de conscientização da realidade da perda, a pessoa enlutada busca reaver a figura perdida, pondo-se a sua procura, mesmo que inconscientemente, expressando raiva, choro e protesto. De fato, a consciência da irreversibilidade da perda desperta profunda tristeza, que alterna com a esperança diante da fé, consciente ou não, em sua reversibilidade ${ }^{59}$.

- desorganização e desespero: a necessidade de buscar e reaver a figura perdida muitas vezes intensa nas primeiras semanas e meses - diminui gradativamente com o tempo, cedendo espaço à fase de desespero, quando a pessoa enlutada reconhece a irreversibilidade da perda e a impossibilidade de recuperar a figura perdida, vivenciando desmotivação pela vida, apatia e depressão ${ }^{53}$.

- reorganização: com o tempo, a depressão, a desesperança e a intolerância às mudanças, diminuem, tornando possível o investimento afetivo em novas figuras. Os modelos operativos internos são remodelados permitindo adaptação às mudanças ocorridas ${ }^{53}$. 
Ressalta-se que os modelos operativos internos constituem estruturas fundamentais do sistema comportamental de apego, construídos desde a infância e o estabelecimento de relações de apego, e atuam como lentes por meio das quais o ser humano pode compreender o mundo, observar eventos, interpretar as informações captadas pelos órgãos dos sentidos, significar suas experiências, elaborar planos e desenvolver expectativas para o futuro ${ }^{62}$. Com efeito, a vivência de perdas e o rompimento de vínculos estão estreitamente relacionados ao estabelecimento do apego e modelos operativos internos ${ }^{50}$.

No que tange à saudade e busca da figura perdida, a raiva, decorrente da frustração inerente à incapacidade de reavê-la, pode ser direcionada aos, então, responsáveis pela perda, ou transferida para outras figuras. A frustração, associada às repetidas tentativas de recuperar a figura perdida, determina a necessidade de rever o modelo operativo interno de apego, considerando a realidade permanente da perda ${ }^{50}$.

O comportamento de busca caracteriza-se ainda por: alerta, tensão e estado de vigília; inquietude; preocupação relacionada à figura perdida; desenvolvimento de um conjunto perceptivo para a figura perdida; desinteresse pela aparência pessoal e por outros assuntos que outrora ocupariam sua atenção; atenção dirigida para os locais aonde a figura perdida poderia estar; invocação da figura perdida; sensação de presença da figura perdida e sonhos com a figura perdida ${ }^{63}$.

Destaca-se que raramente a pessoa enlutada reconhece ou tem consciência de que objetiva reencontrar a figura perdida; e o seu comportamento é considerado pelos outros e por ela mesma como sem sentido. A manutenção de uma sensação ou impressão de proximidade da figura perdida, embora desprovida de atributos visuais e auditivos, contribui para a diminuição da dor do luto e o aumento na percepção de segurança ${ }^{63}$. Destarte, mesmo definitivamente ausente, a figura perdida acaba sendo "reencontrada"

Concernente à persistência em se relacionar com o ente querido perdido, enfatiza-se que, após vivenciar uma perda significativa, os seres humanos tendem a preservar os vínculos em detrimento de abandona-los. Conservar o sentimento de continuidade da presença do ente querido parece ter importância fundamental no processo de elaboração do luto de muitas pessoas, desde que esteja desvinculado da busca, frustração, raiva, culpa e esperança de poder reencontra-lo materialmente, como no início da fase de saudade e busca da figura perdida ${ }^{65}$.

Deste modo, torna-se imprescindível transformar a relação, ponderando a realidade da ausência física. Entretanto, a continuidade dessa relação pode ser alcançada por meio da conservação de valores e objetivos construídos com o ente querido perdido ${ }^{53}$. Logo, o 
"trabalho de luto" não caracteriza um mecanismo de desapego do ente querido perdido, mas um mecanismo de integração da morte. Neste caso, mesmo diante da impossibilidade de contato físico, o ente querido perdido pode representar uma base segura, acessada por meio de sua internalização e evocação de sua imagem, em um nível de representação mental ${ }^{65}$.

Posteriormente, estruturado no conceito de fases do luto proposto por Bowlby ${ }^{53}$, bem como no modelo de "trabalho de luto" descrito por Freud ${ }^{48}$, Worden ${ }^{66}$ propôs o conceito de tarefas do luto, subdividindo-o em quatro tarefas:

- aceitar a realidade da perda, apropriando-se do teste de realidade de que a morte ocorreu;

- lidar com o impacto emocional da perda.

- adaptar-se a um ambiente desprovido da presença do ente querido perdido.

- reposicionar, adequadamente, o ente querido perdido em sua vida emocional; encontrar maneiras de resgatar suas reminiscências; transformar a relação com o mesmo; e reinvestir na vida.

Vale lembrar que os conceitos de fases e tarefas do luto não são excludentes, mas complementares. As tarefas explicitam as necessidades da pessoa enlutada em cada momento de elaboração do luto, enquanto as fases descrevem as reações e emoções experienciadas no decorrer do processo de elaboração. Ambos auxiliam na compreensão da vivência emocional da pessoa enlutada, bem como na avaliação da efetividade da elaboração do luto, em determinado momento ${ }^{50}$.

Adverte-se que a subdivisão do processo de luto, em fases ou tarefas, pode contribuir para regulamenta-lo e estandardiza-lo, negando sua complexidade e a unicidade de cada experiência. Embora as tarefas possam conduzir o aconselhamento e a terapia do luto, nem todas as pessoas enlutadas as vivenciam, tampouco seguem uma ordem específica. Assim sendo, é necessário considerar as diferenças individuais e culturais, sobretudo a possibilidade de distintas trajetórias de adaptação ${ }^{67}$.

Com efeito, a tentativa de atribuir fases e tarefas ao luto, supostamente experienciadas pelas pessoas enlutadas, constitui um risco de delimitar a diversidade de reações à perda ${ }^{50}$, e avaliar de modo injusto, genérico e preconceituoso, a condição vivenciada pela pessoa enlutada, em detrimento de suas peculiaridades ${ }^{68}$. Porém, reafirma-se a relevância de tais conceitos na compreensão do luto, desde que se apreenda que não se tratam de 
normatizadores do luto e que a vivência da perda é singular e depende dos significados conferidos pela pessoa enlutada e pela sociedade em que está inserida ${ }^{50}$.

Outros autores ${ }^{24,63}$ corroboram a divisão apresentada por Bowlby ${ }^{53}$, enfatizando, no entanto, que devem ser compreendidas como padrões comportamentais e não como fases cronológicas $^{59}$. Diante do exposto, observa-se que ao contrário dos estudos iniciais sobre o luto, que propunham o desligamento, o afastamento da pessoa falecida, reforçando a expressividade emocional, os estudos contemporâneos sugerem outras possibilidades como a construção de significado e a manutenção de vínculos contínuos ${ }^{69}$, por meio de ininterrupto engajamento com lembranças e imagens do ente querido perdido, e interiorização de sua imagem, reconstruída para permitir um apego psicológico positivo ${ }^{70}$.

Quanto à perda de um ente querido, evidencia-se a existência de um vínculo internalizado que se conserva e é resignificado ao longo do processo de elaboração do luto, ou seja, da construção de significados ${ }^{50: 12}$. Nesse contexto, construção de significados significa buscar sentido para a vida ${ }^{71}$ e envolve os significados que o ser humano atribui a si mesmo e ao mundo ${ }^{50}$. Logo, esse processo de reconstrução de recursos individuais, de enfrentamento e adaptação às mudanças decorrentes da perda, subsidia a reorganização de si e do mundo ao seu redor ${ }^{72}$.

Salienta-se que a construção de significados atribuídos à morte é referenciada como imprescindível no processo de elaboração do luto $^{73,74,75,76,77,78}$. Trata-se de representações cognitivas preservadas nas reminiscências de cada familiar enlutado, porém construídas interativamente no cerne da família, sob a influência da sociedade, da cultura e do período histórico $^{78}$. Não obstante, a descrição acerca desses significados - quais são e como podem facilitar ou dificultar o processo de elaboração do luto - é pouco abordada na literatura ${ }^{50}$.

Dentre os fatores que estimulam o processo de construção de significados na família, destacam-se os rituais familiares, os efeitos na família estendida, a capacidade de tolerar as diferenças, e a qualidade e frequência das interações. Por outro lado, os fatores inibidores deste processo, abrangem as regras familiares, como impedir que se converse sobre assuntos delicados, e a proteção e os aspectos da dinâmica familiar, como a exclusão de membros ${ }^{78}$. Nessa perspectiva,

A morte pode ser entendida como um teste, um modelo para outros; pode ser-lhe atribuído o objetivo de unir a família; pode ter causa genética; pode-se imaginar que o morto não está em lugar algum, ou que está no céu, cuidando dos outros; pode-se considerar que o morto queria morrer. O significado mais difícil: a morte poderia ter sido evitada ${ }^{78: 401}$. 
Seguindo este pensar, é possível categorizar os significados comumente encontrados na prática clínica ${ }^{78}$.

- o que a morte não foi;

- "não faz sentido";

- morte injusta (coisas ruins acontecendo com pessoas boas; morreu a pessoa errada; morreu muito cedo ou morreu tarde);

- significados filosóficos (fatalidade ou propósito da morte);

- vida após a morte (existe ou não existe);

- significados religiosos (revelação; reunião; recompensa; um teste; causada por Deus);

- natureza da morte (evitável pelo morto, pela família ou pelo sistema de saúde; causa biológica; momento da morte; morte antes da morte);

- atitude do morto em relação à morte (não queria morrer; estava pronto para morrer; desejava morrer; sabia que ia morrer; morreu como queria);

- como a morte mudou a família;

- lições aprendidas, verdades vividas (não ter certezas; estabelecer prioridades; viver a vida ou o momento).

Nesse ínterim, uma nova estrutura analítica de compreensão dos fenômenos inerentes ao processo de luto - Modelo do Processo Dual - surge com a proposta de revisar as concepções teóricas acerca deste processo, evidenciando-o como um enfrentamento adaptativo que confronta ou evita a perda, de acordo com as necessidades de restauração da pessoa enlutada ${ }^{79}$. Logo, a compreensão de que o luto integra a historicidade humana implica em renegar a condição patológica a ele atribuída no início dos estudos sobre a temática ${ }^{56}$.

Idealizado por dois dos mais atuantes pesquisadores da área de luto na atualidade, Stroebe e Schut, o Modelo do Processo Dual ${ }^{79}$, que incorpora o princípio do "trabalho de luto", ampliando sua conceituação acerca do processo de adaptação, defende a ideia de que a pessoa enlutada oscila entre o enfrentamento orientado para a perda (lidar com a perda; concentrar-se nela; e trabalhar algum de seus aspectos), e o enfrentamento orientado para a restauração (cumprir as tarefas; reorganizar a vida e desenvolver novas identidades) ${ }^{50}$.

Deste modo, o Modelo do Processo Dual ${ }^{79}$ auxilia na compreensão de como se dá o processo de elaboração do luto, ao esclarecer que tanto o "trabalho de luto" quanto o seu afastamento são necessários ${ }^{50}$. Essa alternância entre ambos os referidos movimentos, bem 
como o não enfrentamento - distração absoluta; atividades cotidianas desvinculadas à perda constitui um processo regulatório, dinâmico e imprescindível para o enfrentamento $\operatorname{adaptativo~}^{68,79}$.

Nessa perspectiva, a evolução progressiva, porém não linear, do enfrentamento voltado para a restauração, reflete sua elaboração e pode somar-se aos conceitos retromencionados, dinamizando sua apreensão ${ }^{50}$. Ressalta-se a possibilidade de se confrontar e evitar as tarefas de restauração ${ }^{79,80}$, bem como a tendência das mulheres se orientarem mais para a perda, em relação aos homens ${ }^{80}$.

No entanto, diante da inexistência de instrumentos específicos para mensurar as características do Modelo do Processo Dual $^{79}$ (enfrentamento voltado para a perda, enfrentamento voltado para a restauração e oscilação), desenvolveu-se, com base neste referial teórico, o Inventory of Daily Widowed Life (Inventário da Vida Cotidiana da Viúva, IDWL), com o intuito de acessar as estratégias de enfrentamento do enlutado ${ }^{81}$.

Adverte-se que a oscilação deve ser avaliada considerando-se todos os fatores intervenientes no processo de luto: "contexto sociocultural, circunstâncias da morte, dinâmica familiar, relação com o falecido, recursos do enlutado para o enfrentamento" ${ }^{, 0: 25}$. Com efeito, situações que envolvem "morte violenta, repentina, muito sofrida ou que inverta a ordem natural das coisas - filhos que morrem antes dos pais" - tendem a complicar ou prolongar o processo de luto $^{18: \mathrm{VII}}$.

Vale destacar que em ambos os enfrentamentos é possível construir significados positivos (reavaliação positiva; revisão de objetivos de forma construtiva; interpretação positiva da perda; expressão positiva de afeto) e significados negativos (ruminação; construção da realidade de acordo com o seu desejo; revisão de objetivos de forma não construtiva; interpretação negativa da perda; disforia) ${ }^{68,79}$.

Nesse contexto, é possível identificar dois desfechos: o luto pode evoluir para um estado de aceitação ou para um Transtorno do Luto Prolongado (TLP), onde o luto é considerado um processo normal e inerente ao ciclo da vida, e o processo de luto, um mediador da interface entre a perda e a morbidade ${ }^{56}$. Enfatiza-se que aproximadamente $80 \%$ dos enlutados aceitam a perda ao longo do tempo e $20 \%$ a renegam $^{82}$.

O TLP abrange os seguintes sintomas: incapacidade de se preocupar com os outros; ansiedade por, ou preocupação com o ente querido; vida vazia, sem sentido; atordoamento, tontura, ou choque com a morte; dificuldade em aceitar a morte; sensação de que parte de si morreu; dificuldade em seguir em frente com a vida; sensação de dormência; falta de perspectiva futura; dificuldade em confiar nos outros; evitação de lembranças e incômodo 
diante das recordações do ente querido; sentimento de culpa; solidão como um resultado da morte; perda da sensação de segurança; amargura ou raiva relacionada à morte; nervosismo; inveja dos outros que não perderam um ente querido; atração por lugares, coisas associadas ao ente querido; sono perturbado; visão de mundo abalada; perda do senso de controle ${ }^{83}$.

Assim sendo, evidenciam-se fatores de risco sociodemográficos e psicossociais para TLP como: relações afetivas (pais e cônjuges); dependência do ente querido; perda parental, sobretudo em casos de abuso ou negligência na infância; angústia de separação na infância; tendência a estilos de vida previsíveis, avesso a mudanças; despreparo para a morte ${ }^{84}$. Logo, o diagnóstico de TLP tem potencial para melhorar a detecção e o tratamento eficaz de uma causa substancial de morbidade entre pessoas que sofreram a perda de um companheiro ${ }^{83}$.

Vale lembrar que o luto complicado, outrora denominado luto patológico ${ }^{48,53,59}$, refere-se ao processo de luto malsucedido, caracterizado pela elaboração insatisfatória da perda $^{50}$. A proposta de designar como "luto complicado" as situações em que o luto não teve o curso esperado foi idealizada por Rando ${ }^{85}$. O autor considerava inapropriado o uso do termo "luto patológico", visto que se reportava ao modelo médico e impunha uma distinção inflexível entre o que seria considerado "normal" e "anormal".

$\mathrm{Na}$ concepção de Bowlby ${ }^{59}$, em virtude da influência de processos defensivos, no luto complicado a pessoa enlutada não vivencia os sentimentos e reações inerentes a cada uma das fases. Trata-se de exageros ou distorções dos processos normais decorrentes dos seguintes mecanismos de defesa ${ }^{53}$ :

- fixação: a pessoa enlutada permanece fixada à figura perdida;

- repressão: o desejo de recuperar e recriminar a figura perdida, e as emoções ambivalentes de raiva e saudade adjacentes a esses desejos permanecem reprimidos;

- cisão do ego: a personalidade da pessoa enlutada nega, parcialmente, que a figura de apego esteja perdida; acredita manter contato com ela ou que irá reavê-la em breve, mas, concomitantemente, tem consciência de que ela está perdida. Embora essas visões sejam incongruentes, podem coexistir por muitos anos.

- deslocamento: transferência da raiva sentida em relação à figura perdida para si.

Ressalta-se que os processos defensivos emergem no momento em que a pessoa entrevê, conscientemente, que a informação poderia desencadear sofrimentos associados a um contato emocional com a ambivalência afetiva, conflito ou culpa; e que os mecanismos de defesa contemplam a repressão de um ou ambos os elementos do conflito, o amor e o ódio ${ }^{50}$. 
Nesse sentido, o processo de elaboração do luto depende da personalidade da pessoa enlutada, especialmente da sua capacidade de estabelecer relações afetivas e reagir a situações estressantes $^{53}$.

Com efeito, a qualidade do vínculo com a figura de apego e o modo como foi estabelecido, influenciam o modo como se vivencia o seu rompimento, os recursos disponíveis para o enfrentamento e a elaboração da perda, e o estabelecimento de vínculos futuros $^{53}$. Nessa perspectiva, o estilo de apego constitui o principal fator determinante de complicação do luto, sendo corroborado por diversos pesquisadores que estudam esse processo $^{24,86-89}$.

Enfatiza-se que estudos recentes têm adotado o termo "luto complicado" como referencial teórico ${ }^{67,} 87,90-93$. Todavia, não existe um consenso acerca dos critérios estabelecidos para o diagnóstico do luto complicado. Logo, todos os esforços devem convergir para o aprofundamento do conhecimento sobre o luto e suas complicações, o direcionamento de futuras pesquisas, o estabelecimento de critérios diagnósticos confiáveis e atitude ética, com o intuito de melhorar a assistência à pessoa enlutada ${ }^{50}$.

Salienta-se que a experiência do luto compromete todo o sistema familiar. Ocorre um descompasso entre as adaptações, simultaneamente emergentes, e os recursos disponíveis, no momento, para lidar com este processo, ou seja, o encontro com a morte desencadeia uma sobrecarga emocional e relacional sistêmica na família, que excede sua capacidade intrínseca de resiliência. Para superar esta crise, o sistema familiar precisa rearranjar-se e, consequentemente, reconstruir sua identidade e seu limiar de equilíbrio ${ }^{24}$.

No que tange ao suporte espiritual/religioso, o pressuposto de que "os significados de morte e luto ligados às crenças religiosas e a espiritualidade podem interferir na elaboração do luto", conduziu a realização de um estudo clínico-qualitativo com seis viúvas idosas. Os resultados enfatizam que a crença em Deus pode contribuir significativamente para a construção de significados concernentes à restauração da perda; a religião pode subsidiar discernimento em relação à morte de um ente querido; a crença na vida após a morte e a concepção de morte enquanto "chamado divino" podem facilitar o processo de elaboração do luto $^{94: 589}$.

A Igreja, concebida como comunidade que compartilha a mesma fé, pode viabilizar um espaço de socialização e expressividade emocional, caracterizando-se como um suporte imprescindível neste processo. A fé em Deus pode constituir uma estratégia de enfrentamento da ansiedade inerente à saudade e busca do ente querido. A religiosidade pode proteger contra a depressão e o sentimento de tristeza relacionado à solidão. Diante do exposto, é possível 
inferir que "a espiritualidade, expressa como a fé e a crença em Deus, e a religião, possuem um papel mais positivo na elaboração do luto do que se atribui comumente na literatura"94:594.

Embora tenham emergido de paradigmas distintos, as teorias retromencionadas apresentam importantes aportes para a compreensão do luto em sua complexidade. À guisa de conclusão, o "luto é o processo normal e esperado de elaboração psíquica e enfrentamento da vivência de perdas significativas [...] que implica a transformação e ressignificação da relação com o que foi perdido" ${ }^{, 50: 12}$.

Trata-se de uma reação natural e esperada diante da ruptura de um vínculo, de uma relação, de um projeto ou de um sonho. É um processo dinâmico, subjetivo e multidimensional de elaboração de uma perda significativa, delineado por sofrimento emocional intenso ${ }^{18}$. Pode ser considerado, também, como uma experiência humana que não pode ser evitada, prevista, resolúvel ou superada, e que questiona os estágios outrora descritos $^{95}$. É conceituado como um processo

\begin{abstract}
por ser uma experiência que não se coloca estaticamente em dado momento da vida, que requer que eventos aconteçam, que percepções se deem e atuem sobre esses eventos, que novas situações se apresentem e possam ser significadas. É um processo particular, não há dois processos idênticos. Isso se deve ao fato de não existirem duas relações significativas idênticas. Logo o processo sempre vai ser específico e subjetivo $^{78: 398}$.
\end{abstract}

Não obstante, a cultura que compartilhamos pode conferir condições de universalidade aos significados que atribuímos às experiências que vivenciamos, inclusive ao processo de luto. Ponderando que a dimensão espiritual contribui para que o processo de viver e morrer aproxime a pessoa de sua humanidade, de sua condição humana, é possível ter uma breve noção da complexidade inerente ao processo de luto ${ }^{78}$.

De fato, "ninguém permanece o mesmo após viver um luto, e essa transformação é ampla e profunda, muito mais do que uma experiência dolorosa em uma dada medida normal e suportável" ${ }^{, 56: 56}$. Ressalta-se que elaborar o luto significa confrontar a impotência e os limites humanos, e a realidade de que não controlamos o mundo, sobretudo as pessoas que amamos, porque não fazem parte de nós. "Em última instância, significa depararmos com a possibilidade do nosso limite total, a morte, ${ }^{, 50: 16}$.

Por integrar e configurar a existência humana, o processo de elaboração do luto implica em aceitar e adaptar-se às transformações decorrentes da perda, tanto do mundo externo quanto do mundo interno, reorganizando a vida e as relações ${ }^{96}$. Destarte, o luto não se encerra com o retorno à normalidade. É preciso que a pessoa enlutada incorpore a perda em 
sua vida, no sentido de continuar vivendo, conectado ao falecido, mas seguindo adiante ${ }^{18}$. Esse processo de readaptação, que despende tempo e esforço da pessoa enlutada, é denominado Transição Psicossocial e ratifica a instabilidade relacionada às orientações para a perda e para a restauração na elaboração do luto ${ }^{63}$. Seguindo este pensar,

\begin{abstract}
lidar bem com o luto significa poder enfrentar os sentimentos evocados pela perda [...] e também poder ter momentos de evitar a dor e se voltar para a vida. Ao perceber que o ente amado não retornará, surge a melancolia e o enlutado necessita de tempo para aceitar a realidade da morte, transformar sua relação com a pessoa perdida e sua própria identidade sem ela. Cada um experimenta o processo de luto à sua maneira. Toda vez que alguém rememora sua perda, volta a sentir uma intensa tristeza, as lágrimas ameaçam invadir novamente seus olhos, mas não muito tempo depois é possível encontrar um conforto ${ }^{18: \mathrm{VII}}$.
\end{abstract}

Diante do exposto, e da intencionalidade de cuidar de familiares enlutados, estruturado no preceito paliativista de oferecer um sistema de apoio para ajudar a família a lidar com o luto, vislumbrei as possibilidades terapêuticas da música enquanto recurso complementar no cuidado de Enfermagem.

\title{
3.3 ESPIRITUALIDADE E RELIGIOSIDADE
}

Historicamente, a espiritualidade e a religiosidade sempre foram consideradas importantes suportes para as pessoas que sofrem e/ou adoecem ${ }^{97}$ e em diversos estudos, estiveram associadas à melhor saúde física e mental ${ }^{98}$, 99 , sugerindo possível fator de prevenção, eventual aumento de sobrevida e impacto significativo sobre diversas doenças ${ }^{99}$, 100

Nesse sentido, o Handbook of Religion and Health ${ }^{98}$ evidencia os efeitos benéficos das crenças e práticas religiosas/espirituais sobre diversos indicadores de saúde, como melhor função imunológica e controle da pressão arterial; menor nível de estresse, consumo de álcool e outras drogas, e utilização dos serviços de saúde; maior nível de bem-estar geral, esperança, otimismo e suporte social. Com efeito, a espiritualidade e a religiosidade subsidiam o enfrentamento de adversidades e eventos estressantes e traumáticos ${ }^{101}$.

Estudos recentes têm identificado, ainda, menor prevalência de depressão, tempo de hospitalização e incidência de suicídio; melhor qualidade de vida; maior sobrevida, dentre outros $^{99,}{ }^{102}$. Concernente à saúde mental, os resultados positivos relacionados à espiritualidade incluem o bem-estar, a felicidade, a esperança, o otimismo, a gratidão e a autoestima, e estão relacionados a traços psicológicos positivos como altruísmo, gentileza, 
compaixão, perdão e gratidão; e os resultados negativos envolvem depressão, suicídio, ansiedade, psicose, abuso de drogas, delinquência/crime, instabilidade conjugal, e traços de personalidade (positivo e negativo) ${ }^{99}$.

Ressalta-se que a Organização Mundial da Saúde reconhece a importância da espiritualidade e da religiosidade em seu conceito de Saúde, bem como no Instrumento de Qualidade de Vida - Módulo Espiritualidade, Religião e Crenças Pessoais (WHOQOLSRPB) $)^{97,103}$. Não obstante, estudar espiritualidade e religiosidade implica em confrontar o desafio de discernir conceitos tão complexos e sobrepostos ${ }^{101}$.

Outro agravante refere-se à negligência em estudar essas dimensões como desfechos em saúde ou variáveis preditivas, decorrente de preconceito, desinteresse ou dificuldade em mensura-las ${ }^{103}$. Porém, é crescente o número de pesquisas sobre espiritualidade na área da saúde, sobretudo na Enfermagem, refletindo uma mudança paradigmática, na tentativa de ampliar as possibilidades de aliviar o sofrimento humano ${ }^{104}$.

Com efeito, a aproximação entre as ciências e os temas outrora denominados religiosos intensificou-se nos últimos tempos, e a inserção da espiritualidade no atendimento em saúde tem ocorrido por vias distintas, sobretudo por meio da retomada dos valores inerentes ao cuidado humano, evidenciando a importância cultural dos aspectos religiosos, imprescindíveis no processo de cura/reabilitação de doenças ${ }^{105}$.

A produção científica concentra-se no significado filosófico do conceito de espiritualidade, métodos de avaliação das necessidades espirituais e aspectos práticos de suas implicações no cuidado de Enfermagem ${ }^{104}$. Ponderando a impossibilidade de analisar a espiritualidade e a religiosidade isoladamente, elaborou-se um esquema didático (Figura 1) para melhor compreender as dimensões do ser humano e sua relação com o espiritual ${ }^{106}$.

A dimensão física $(\varphi)$ representa os aspectos biológicos do ser humano, o corpo e os sofrimentos a ele relacionados (dor, dispneia, náuseas, vômitos, astenia, caquexia, confusão mental, depressão, ansiedade etc.). A dimensão psíquica $(\psi)$ abrange o medo, a raiva, as mágoas, as alegrias e as tristezas. A dimensão social-cultural $(\delta)$ engloba a etnia, a nacionalidade, a religião, escolaridade, classe social e sofrimentos a elas inerentes. A dimensão familiar-financeira $(\gamma)$, menor núcleo de subsistência humana, relaciona-se com as questões financeiras e seus encargos ${ }^{106}$.

A dimensão existencial $(\varepsilon)$ envolve todas as dimensões supracitadas, atribuindo significados e questionamentos a cada uma delas. Ressalta-se que para "cada um de nós a família, o dinheiro, a cultura, o corpo, as emoções e sentimentos são expressões de nós mesmos com maior ou menor importância e diferentes significados". Por fim, a dimensão 


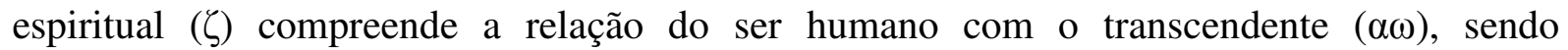
imprescindível diferencia-la das questões existenciais e religiosas ${ }^{106: 271}$.

Alguns autores consideram as dimensões existencial e espiritual como sinônimo, o que é parcialmente apropriado, considerando que todas as coisas que dão significado à vida humana (família, trabalho, religião etc.) podem estar relacionadas com o transcendente (Deus, o metafísico, o sobrenatural ou o sagrado). Embora a religião instituída pertença à dimensão social-cultural, pode ser considerada, também, espiritual, se realmente intermediar a relação do ser humano com o transcendente. Todavia, cada religião expressa a espiritualidade de um povo, conforme suas características socioculturais ${ }^{106}$.

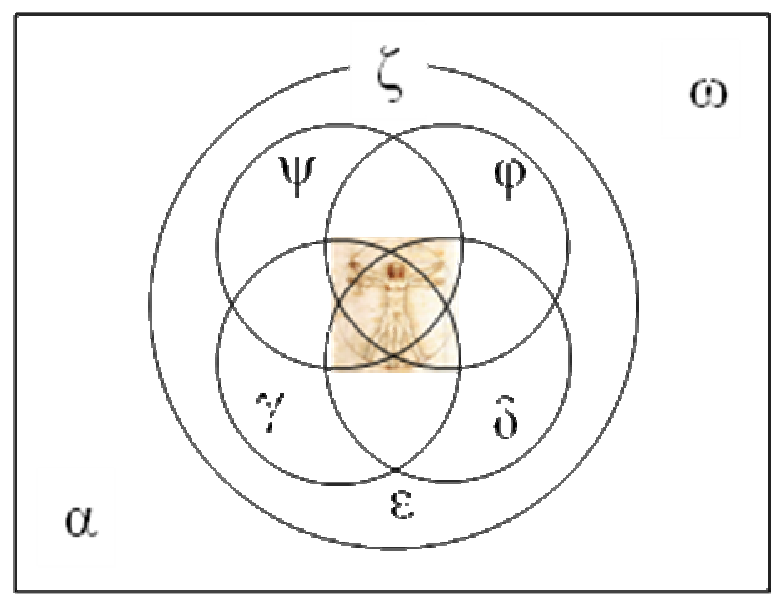

Figura 1. Dimensões do ser humano: $\varphi$ física, $\psi$ psíquica, $\gamma$ familiar-financeira, $\delta$ social-cultural, $\varepsilon$ existencial, $\zeta$ espiritual e $\alpha \omega$ transcendente $^{106}$.

Etimologicamente o termo espiritualidade deriva do latim spiritus e significa sopro de vida $^{107}$, ou a dimensão humana que domina a mente e o corpo. Nessa perspectiva, a espiritualidade está relacionada com tudo aquilo que traz significado e sentido à vida humana ${ }^{108}$. Enfatiza-se que os elementos ou atributos essenciais da espiritualidade - realidade existencial, conectividade, significado, sentido, esperança, relacionamentos, transcendência, experiências existenciais e força/poder/energia - têm sido identificados em estudos de revisão integrativa $^{107,109}$.

A "conectividade" refere-se à relação com Deus, com os outros, com a natureza e consigo mesmo; o "sentido" refere-se ao significado ontológico atribuído à vida, emergente de experiências distintas; os "valores" referem-se às crenças e padrões culturalmente aceitos, estimados por meio de comportamentos intrínsecos a determinados povos; a "transcendência" 
refere-se às experiências subjetivas; e o "tornar-se", refere-se à busca pela plenitude existencial $^{110}$.

Destarte, espiritualidade pode ser definida como uma busca individual para compreender questões existenciais sobre a vida e o seu sentido, e as relações com o sagrado ou o transcendente, que pode ou não subsidiar o desenvolvimento de práticas religiosas ou a formação de comunidades religiosas ${ }^{98}$. Para a OMS, que inclui a dimensão espiritual no conceito multidimensional de saúde, a espiritualidade constitui um conjunto de emoções e convicções imateriais, supondo a existência de algo imperceptível ou parcialmente incompreendido, remetendo a questões existenciais, irrestritamente a qualquer tipo específico de crença ou religião ${ }^{111}$.

Validamente, o conceito de espiritualidade é altamente contestado ${ }^{112}$. A dificuldade em conceitua-la tem estimulado consideráveis debates e confusões, em virtude da diversidade e evolução de suas compreensões na sociedade em geral ${ }^{107}$. Entretanto, a existência de uma enorme variedade e diversidade de definições na literatura de Enfermagem, não a torna irrelevante ou de pouca utilidade na prática clínica. Muito pelo contrário; devidamente entendida, esta indefinição e falta de clareza em torno do termo espiritualidade representam uma força que tem poderosas implicações clínicas, sociais e políticas ${ }^{112}$.

Logo, cada ser humano encontra o sentido de sua vida de um modo distinto, conferindo unicidade, dinamicidade e subjetividade à espiritualidade ${ }^{113}$. Trata-se de um encontro de autoconhecimento do ser humano com a sua dimensão espiritual, que permite conectividade consigo mesmo e com o cosmo, atingindo recursos inigualáveis que influenciam sua vida e suas relações com o Todo ${ }^{104}$.

Nesse contexto, o bem-estar espiritual refere-se à percepção subjetiva de bem-estar do ser humano em relação à sua crença. Diante da complexidade de mensurar a espiritualidade, o bem-estar espiritual constitui um de seus aspectos passíveis de avaliação. Todavia, é importante ressaltar a impossibilidade de determinar, com exatidão, os mecanismos intervenientes da espiritualidade na saúde humana, especialmente na saúde mental ${ }^{111}$.

Deste modo, nenhuma definição contempla toda a essência do seu construto, porém, cada definição representa um direcionamento em busca da completude de sua compreensão bem como dos elementos essenciais do cuidado espiritual ${ }^{114}$. Contudo, sugere-se que a prática de exercícios espirituais (oração e outros rituais) pode estimular possíveis mecanismos psicodinâmicos, psiconeurológicos, psicoimunológicos e psicofisiológicos, por meio de emoções positivas (esperança, perdão, autoestima e amor) importantes para a saúde mental ${ }^{111}$. 
Vale lembrar que a religião constitui um sistema organizado de crenças, práticas, rituais e símbolos que configuram e determinam o modo como as pessoas acessam o sagrado ou transcendente (Deus, força maior, verdade suprema...) ${ }^{98,110}$. A religiosidade, por sua vez, representa a extensão caracterizada pela crença, seguimento e prática religiosa, que pode ser organizacional ou não organizacional ${ }^{98}$.

Ampliando este conceito, destaca-se a classificação do Índice de Religiosidade de Duke (DUREL) ${ }^{115}$, desenvolvido nos Estados Unidos e validado no Brasil. Trata-se de uma escala que mensura três das dimensões do envolvimento religioso que mais se relacionam com os desfechos em saúde: organizacional (frequência em encontros religiosos como missas, cultos, cerimônias, grupos de estudo ou de oração etc.); não organizacional (frequência em atividades religiosas privadas como orações, meditação, leitura de textos religiosos, ouvir ou assistir programas religiosos na Televisão ou no rádio etc.); intrínseca (busca de internalização e vivência da religiosidade em sua plenitude, como principal objetivo do ser humano; fins imediatos são considerados secundários e alcançados em harmonia com princípios religiosos básicos) $^{116}$.

Estudos de revisão evidenciam associações positivas entre o envolvimento religioso e a saúde mental, sugerindo que quanto maior o envolvimento religioso, maior o nível de bemestar psicológico, menor a prevalência de depressão, consumo de drogas e ideação e comportamentos suicidas ${ }^{117,118,119}$. Tais associações se justificam por quatro razões: as crenças religiosas influenciam a visão de mundo, atribuindo significado às experiências; as crenças e práticas religiosas, de modo geral, evocam emoções positivas; os elementos religiosos facilitam e santificam as transições mais importantes da vida, como a morte; a religiosidade encoraja comportamentos socialmente aceitáveis ${ }^{98}$.

Embora sejam considerados conceitos independentes, espiritualidade e religiosidade se correlacionam, haja vista que a espiritualidade pode se manifestar no contexto religioso, assim como a religiosidade engloba experiências espirituais ${ }^{101}$. Nesse contexto, o coping constitui a habilidade humana de lidar com as adversidades da vida ${ }^{120}$. Trata-se de um processo situacional, em que as pessoas utilizam estratégias cognitivas e comportamentais para se adaptarem aos eventos estressantes ${ }^{108,121}$.

Ressalta-se que a resposta ao estresse envolve reações emocionais ou comportamentais espontâneas, enquanto o objetivo do coping compreende a intencionalidade de uma resposta, cuja orientação, em geral, objetiva reduzir o estresse ${ }^{108,}{ }^{121}$, modificar o ambiente, a interpretação ou o comportamento das pessoas de modo a sentir-se menos ameaçada $^{120}$. O coping religioso/espiritual, por sua vez, compreende a utilização de crenças e comportamentos 
religiosos, com o intuito de subsidiar a solução de problemas, prevenir ou aliviar consequências emocionais negativas ${ }^{108,122}$. Com efeito, voltar-se para a religião constitui um importante mecanismo de coping em tempos de angústia ${ }^{123}$.

Enfatiza-se que esse conceito se ancora em quatro pressupostos: a existência de uma ameaça, dano ou desafio; a autoavaliação da situação; os recursos disponíveis para lidar com $\mathrm{o}$ estresse; e a responsabilidade inerente à experiência ${ }^{124}$. No entanto, coping religioso/espiritual, bem como suas estratégias, podem ser positivos ou negativos ${ }^{125-126}$. O coping religioso/espiritual positivo abrange estratégias - busca por proteção, segurança ou maior conexão com Deus ou forças transcendentais; busca por conforto ou ajuda na literatura religiosa, dentre outros - que podem proporcionar resultados benéficos à pessoa, subsidiando melhor qualidade de vida ${ }^{108,125-128}$.

Por outro lado, o coping religioso/espiritual negativo, compreende as estratégias que desencadeiam resultados prejudiciais à pessoa, como questionar a própria existência; atribuir a Deus a resolutividade de seus problemas; encarar a condição de estresse como punição Divina; insatisfação ou descontentamento em relação a Deus ou membros de uma instituição religiosa, dentre outros, resultando em menor qualidade de vida ${ }^{108,125-128}$.

Diante do exposto, é importante destacar que, de acordo com a National Hospice and Palliative Care Organization ${ }^{129}$, não precisa ser um líder religioso para oferecer suporte espiritual às pessoas sob cuidados paliativos ${ }^{119}$. Sugere-se, portanto, as seguintes proposições:

- a simples presença de um apoiador espiritual é importante por si só, mesmo que permaneça em silêncio;

- utilizar questões abertas sobre o tema, permitindo que a pessoa se sinta à vontade para falar sobre aquilo que lhe for confortável no momento;

- solicitar sua permissão e questione sua vontade de conversar sobre o tema;

- estar aberto à sua expressividade emocional (tristeza, raiva, culpa, negação, esperança, alegria, paz);

- evitar clichês do tipo "É parte do plano de Deus" ou "Tudo acontece por uma razão", pois podem desencorajar o processo de abertura;

- expressar sua intencionalidade de apoia-la, incentiva-la ou cuida-la e ser autêntico em tudo o que disser ou fizer;

- ofertar orações, leituras espirituais, músicas ou rituais sagrados, adequados à crença da pessoa; 
- sempre que possível, estimular o envolvimento de clérigos, capelães ou líderes espirituais experientes nesse tipo de cuidado;

- lembrar-se de que a oferta de compreensão e suporte espiritual pode subsidiar conforto, sentido e esperança, imprescindíveis neste momento.

Diante do exposto, torna-se imprescindível que os profissionais de saúde, sobretudo os enfermeiros, compreendam o significado da espiritualidade e da religiosidade para as pessoas que cuidam, bem como a influência de eventos significativos no modo com que lidam com isso, para que, na prática clínica, tais fenômenos possam integrar realmente o cuidado holístico ${ }^{130}$. A espiritualidade também pode fundamentar e determinar as ações do enfermeiro, promovendo interação efetiva, estabelecimento de vínculos e segurança para os pacientes e familiares em relação aos cuidados de Enfermagem ${ }^{131}$.

No que tange aos diagnósticos de Enfermagem, a North American Nursing Diagnosis Association (NANDA) reconhece o "Sofrimento espiritual", outrora denominado "Angústia espiritual", como diagnóstico de Enfermagem, inerente ao domínio "Princípios de vida", definindo-o como a capacidade prejudicada de perceber e associar o significado e sentido da vida por meio de uma conexão consigo mesmo, com os outros, a arte, a música, a literatura, a natureza e/ou um ser superior ${ }^{132}$. Vale lembrar que pesquisadores brasileiros sugerem que o título diagnóstico que melhor descreve os prejuízos sofridos na dimensão espiritual é "Espiritualidade prejudicada"130,133.

Concernente às intervenções de Enfermagem, a prece é referenciada na Nursing Interventions Classification (NIC) como uma proposta de suporte espiritual e facilitação do crescimento espiritual ${ }^{134}$. Trata-se de "uma estratégia para suprir as necessidades espirituais do paciente, que pode ser considerada uma técnica para acalmá-lo"135:685. Com efeito, a oração pode ser implementada por meio da petição, quando a pessoa que ora pede a Deus algo para si; ou por meio da intercessão, quando a pessoa que ora pede a Deus algo para o outro ${ }^{136}$.

Nessa perspectiva, com o intuito de contemplar a dimensão espiritual do cuidado, a Enfermagem dispõe de diversos recursos, dentre eles a música, cujos efeitos terapêuticos nos seres humanos são apresentados a seguir. 


\subsection{A MUSICOTERAPIA COMO RECURSO DE CUIDADO}

Considerando que a música tem sido utilizada como recurso terapêutico por diversos profissionais, bem como para evitar discussões relacionadas às competências, habilidades e atribuições de cada profissional que a utiliza, optou-se por apresentar e discutir algumas definições de musicoterapia, antes de elencar evidências científicas, produzidas por enfermeiros e musicoterapeutas, que ratificam os benefícios de sua utilização.

De acordo com os Descritores em Ciências da Saúde (DeCS), musicoterapia é o "uso da música como uma terapia adicional no tratamento de distúrbios neurológicos, mentais ou comportamentais" ${ }^{\prime 137}$. Nota-se que a definição apresentada pelo DeCS, cujo descritor musicoterapia - é utilizado na indexação de qualquer intervenção musical, não identifica nenhuma profissão específica.

A Associação Americana de Musicoterapia (AAMT), por sua vez, a define como a utilização, clínica e baseada em evidências, de intervenções de música, para atingir objetivos individualizados inerentes à relação terapêutica, por um profissional credenciado que tenha concluído um programa de musicoterapia aprovado ${ }^{138}$. Deste modo, a AAMT restringe sua utilização aos musicoterapeutas.

Nesse sentido, para ser considerada como uma terapia formal, a musicoterapia deve ser conduzida por um musicoterapeuta treinado. Caso contrário, isto é, quando a terapia é realizada por outros profissionais, seria mais comumente denominada "música como terapia", ou "intervenção musical”, em vez de musicoterapia ${ }^{139}$. Entretanto, a Federação Mundial de Musicoterapia não faz esta distinção, e a define como

o uso profissional da música e seus elementos como intervenção na medicina, na educação, e em ambientes do cotidiano com indivíduos, grupos, famílias ou comunidades que buscam otimizar sua qualidade de vida, e melhorar sua saúde física, social, comunicativa, emocional, intelectual e espiritual, e bem estar ${ }^{140}$.

Vale lembrar a natureza híbrida da musicoterapia, que sobrepõe arte e ciência, ou seja, a música e os fundamentos terapêuticos de sua utilização ${ }^{141}$. Nessa perspectiva, assim como o cuidado, a música não deve ser considerada prerrogativa de uma categoria específica, mas sim de qualquer profissional da saúde, desde que a utilize respaldado em evidências científicas, valorizando a subjetividade construída a partir da afetividade e da criatividade ${ }^{142}$.

Assim sendo, para a Enfermagem brasileira, musicoterapia é a utilização criteriosa da música, enquanto recurso complementar no cuidado ao ser humano, visando à restauração do 
equilíbrio possível, do bem-estar e, em muitos casos, a ampliação da consciência individual no processo saúde-doença ${ }^{143}$, que justifica a apropriação do termo no presente estudo. Não obstante, alguns princípios básicos regem a utilização da música no cuidado de Enfermagem, ponderando as características de universalidade que encerram ${ }^{144}$.

O primeiro deles, de caráter ontológico, se reporta às nossas experiências sonoromusicais, mas, sobretudo, à nossa essência humana - somos seres musicais. O segundo, de caráter físico (vibracional), refere-se ao modo como percebemos e somos afetados pela música, caracterizada como um estímulo - vibrações sonoras - conduzido através do nervo auditivo até o córtex, que desencadeia respostas sensoriais como efeitos fisiológicos, mentais e emocionais $^{144}$.

O terceiro princípio, de caráter musical, está relacionado aos elementos musicais inerentes à musicoterapia proposta. $\mathrm{Na}$ estrutura musical existem elementos que estão atrelados à dimensão física, como o ritmo, ou às emoções, como a melodia. A dimensão social está contemplada no contexto histórico-cultural no qual a música se origina, o que possibilita a sensação de "pertencimento" a um povo, uma região, uma história ou um determinado período. Na dimensão espiritual, por vezes negligenciada, pouco compreendida e investigada, os elementos musicais convergem para articular todas as dimensões humanas, viabilizando um profundo contato com a própria essência, o universo, Deus, ou qualquer outra concepção de espiritualidade ${ }^{144}$.

O quarto princípio, de caráter relacional, reflete a relação interpessoal mediada pela música. A música não acontece sozinha, ou seja, não se trata de um fenômeno desprovido da ação do homem, pois ela é criada por um ser humano. No contexto do cuidado à saúde, ela também não emerge ao acaso, mas da intencionalidade de cuidar. Assim, a música pode facilitar o encontro entre o ser cuidador e o ser cuidado, possibilitando a demonstração de afetividade, compaixão e solidariedade, por meio de gestos, olhares, sorrisos, toques suaves inerentes à execução musical, quando proposta como intervenção ${ }^{144}$.

$\mathrm{Na}$ dimensão física, a música promove relaxamento muscular; interrompe o ciclo vicioso da dor crônica, por reduzir a ansiedade e a depressão, influenciando na percepção da dor; minimiza os efeitos adversos decorrentes da quimioterapia; facilita a participação em atividades físicas, respeitando as limitações individuais ${ }^{145}$. Em um estudo reflexivo acerca do quanto devemos atentar para aquilo que ouvimos, qual é a nossa responsabilidade ao propor música no ambiente de saúde e em quais dimensões humanas ela produz respostas, evidenciou-se que as músicas mais voltadas à dimensão física enfatizam o ritmo, favorecem a 
sensorialidade e incitam a movimentação corporal, como um "convite à dança", devido à resposta talâmica cerebral ${ }^{21}$.

$\mathrm{Na}$ dimensão psicológica, a música reafirma a identidade e a autoestima; influencia o estado de humor do ouvinte; reaviva eventos significativos do passado; promove, por meio da linguagem não verbal, a expressão de subjetividades inconscientes e estimula a imaginação ${ }^{146}$. Sua atuação no psiquismo gera um foco de alívio diante da desorganização proveniente da angústia e da dor ${ }^{147}$. As músicas relacionadas à esfera mental nos conduzem à reflexão acerca do conteúdo de suas letras e podem sugerir o caminho para tocar a espiritualidade. No que tange à dimensão emocional, normalmente são músicas mais melódicas, versam sobre o amor ou a ausência dele, ou sobre saudades, e lideram a evocação de reminiscências, sem garantir uma introspecção significativa ${ }^{21}$.

Emergente da reflexão e afetividade humana, a música evoca significados e sentidos, ou seja, a essência idiossincrática do ser humano e a subjetividade de suas vivências, compartilhadas no contexto social ${ }^{148}$. Enquanto forma de expressão socialmente aceita, na dimensão social a música reflete a interface entre o isolamento e as divergências culturais; promove interação social e entretenimento. Na dimensão espiritual, promove conforto e subsidia a expressão da espiritualidade, de sentimentos e incertezas quanto ao significado da vida e sua finitude ${ }^{145}$.

Vale destacar que o vínculo entre a arte e a medicina se originou na mitologia grecoromana, há 2600 anos. Naquela época, Esculápio utilizava o som de sua lira no tratamento das doenças ${ }^{149}$. Os povos primitivos acreditavam na influência de entidades superiores evocadas por meio do contato com a música em cerimônias místicas e religiosas ${ }^{144}$. No século XVI, com a desmistificação da superstição medieval de que as doenças, principalmente os transtornos mentais, decorriam da influência de demônios, a música desvinculou-se da religião, tornando-se um recurso terapêutico ${ }^{150}$.

Florence Nightingale, ainda no início da organização da Enfermagem como profissão, apreendera os efeitos terapêuticos decorrentes da voz humana e dos instrumentos de sopro e de corda, reverenciando a música como recurso de cuidado ${ }^{151}$. A consciência deste fato, dentre outros, reafirma a percepção de que a Enfermagem não está transitando em território desconhecido, mas que integra sua história enquanto profissão.

No início do século XX, com o regresso dos veteranos da I e II Guerra Mundial, a utilização deste recurso se expandiu no âmbito hospitalar. Esse período foi marcado pela expressiva contribuição da Enfermagem, sobretudo das enfermeiras e musicistas norte 
americanas Isa Maud Ilsen e Harryet Ayer Seymour, para a Musicoterapia e sua projeção enquanto profissão nos Estados Unidos ${ }^{143}$.

Ilsen foi responsável pela criação da Associação Nacional de Música nos Hospitais em 1926 e pioneira no ensino de musicoterapia na Universidade de Columbia ${ }^{22,150}$. Seymour utilizava a música no cuidado aos soldados feridos, fundou uma escola e formou musicistas para tocar a beira do leito de pessoas hospitalizadas, além de fazer vários concertos em hospitais. Em 1941 desenvolveu o "Método Seymour" e criou a Fundação Nacional de Musicoterapia, com o intuito de ampliar os estudos nessa área ${ }^{143}$.

Em 1970, norteada pelo princípio da integralidade e da ressonância, Marta Rogers, enfermeira norte-americana, apreendeu que o "processo de vida nos seres humanos é uma sinfonia de vibrações rítmicas oscilando em várias frequências" e que se propagam por meio de ondas ressonantes interagindo com o ambiente ${ }^{152: 188}$. Deste modo, compreendeu a influência da vibração rítmica das ondas sonoras da música no estado receptivo humano. Esse mecanismo viabiliza a absorção do conteúdo transmitido pela música ou por outro elemento adjacente a ela, ao promover o relaxamento da sensorialidade durante a audição musical ${ }^{153}$.

Atualmente, a musicoterapia integra o escopo das terapias complementares, respaldada pela Política Nacional de Práticas Integrativas e Complementares (PNPIC) do Ministério da Saúde (MS), consolidada pelas Portarias Ministeriais n. 971 de 03 de maio de 2006 e n. ${ }^{\circ}$ 1.600 de 17 de julho de 2006. Nesse contexto, a PNPIC reconhece a Acupuntura, a Homeopatia, a Fitoterapia, e as Terapias Artísticas como recursos tecnológicos eficazes e seguros na promoção e recuperação da saúde de forma humanizada e holística, com ênfase na escuta acolhedora, no desenvolvimento do vínculo terapêutico e na integração do ser humano com o meio ambiente e a sociedade ${ }^{154}$.

Destaca-se ainda a Resolução No 197/1997 do Conselho Federal de Enfermagem (COFEN), por estabelecer e "reconhecer as Terapias Alternativas como especialidade e/ou qualificação do profissional de Enfermagem" ${ }^{\text {"155 }}$. No entanto, a designação desta especialidade tem sofrido algumas modificações ao longo do tempo. A Resolução No 290/2004 do COFEN fixa como Especialidade de Enfermagem, de competência do Enfermeiro, as Terapias Naturais/Tradicionais e Complementares/Não Convencionais ${ }^{156}$. Atualmente, a Resolução 389/2011 do COFEN, que revoga a Resolução No 290/2004 e dispõe sobre as Especialidades de Enfermagem e suas áreas de abrangência, a referencia como Enfermagem em Terapias Holísticas Complementares ${ }^{157}$.

Internacionalmente, a musicoterapia é referenciada no sistema NANDA (North American Nursing Diagnosis Association), NIC (Nursing Interventions Classification) e NOC 
(Nursing Outcomes Classification) como intervenção para, dentre outros, os diagnósticos de Enfermagem relacionados à dimensão espiritual - sofrimento espiritual, ansiedade relacionada à morte, desesperança e disposição para bem-estar espiritual aumentado ${ }^{158}$. $\mathrm{O}$ reconhecimento da musicoterapia como intervenção de Enfermagem assegura tranquilidade e segurança aos enfermeiros que a utilizam em suas práticas clínicas.

Nesse contexto, a musicoterapia objetiva reduzir os sintomas físicos correlatos; melhorar os processos cognitivos; melhorar a integração e/ou adaptação ao ambiente/relações; melhorar os estados de humor e sintomas psicológicos correlacionados; melhorar a saúde espiritual, a esperança e a vontade de viver; subsidiar a superação do processo de pesar e o crescimento espiritual; promover apoio espiritual, assistência ao morrer, esperança, suporte emocional, assistência na automodificação e suporte à família; e incitar a capacidade de resiliência e o processo de meditação ${ }^{158}$.

Com efeito, o interesse da Enfermagem pela musicoterapia tem aumentado e as evidências científicas têm demonstrado sua importância na comunicação e relação clienteenfermeiro e na humanização do cuidado ${ }^{1-3,16,151}$. A constante contribuição da Enfermagem tem possibilitado a compreensão dos mecanismos intervenientes que a música utiliza ao desencadear reações fisiológicas no ser humano, suas indicações e limitações. Estudos têm revelado sua potencialidade terapêutica na redução da dor, do estresse e da ansiedade; na promoção de conforto, relaxamento muscular e dignidade a pessoas hospitalizadas; no resgate de reminiscências e identidade de idosos institucionalizados, dentre outros ${ }^{144}$.

Um estudo de revisão sistemática sobre musicoterapia para melhorar os resultados físicos e psicológicos em pacientes com câncer, que objetivou comparar os efeitos da musicoterapia e cuidado padrão, com o cuidado padrão exclusivo ou o cuidado padrão e outras intervenções, pode corroborar a afirmação retromencionada. A análise de 30 ensaios clínicos randomizados e quase experimentais demonstrou que a musicoterapia pode ter efeitos benéficos na ansiedade, na dor, no humor e na qualidade de vida. Os resultados ainda sugerem que a música pode reduzir, discretamente, as frequências cardíaca e respiratória e a pressão arterial, mas pode não ser clinicamente significativa. Não foi encontrada evidência de efeito para a depressão e fadiga. As autoras concluem que a musicoterapia pode ser oferecida como um tratamento complementar para pessoas com câncer ${ }^{159}$.

Outra revisão sistemática com meta-análise de 32 artigos acerca dos resultados físicos e psicológicos em pacientes com câncer, também encontrou resultados semelhantes: a musicoterapia pode melhorar a qualidade de vida; reduzir a ansiedade e a depressão, antes, durante e após os tratamentos antineoplásicos - cirurgia, quimioterapia e radioterapia; pode 
reduzir a dor e as frequências cardíaca e respiratória, porém não reduz significativamente a pressão sistólica e diastólica; não reduz e pode piorar a fadiga ${ }^{160}$.

Um estudo controlado e randomizado acerca dos efeitos da musicoterapia na qualidade do sono de 42 pessoas idosas, em Singapura, também não encontrou diferenças significativas na pressão arterial e frequência cardíaca entre os grupos experimental e controle. No grupo experimental houve melhora estatisticamente significativa $(\mathrm{p}<0.001)$ na qualidade do sono, especialmente em comparação com os valores basais e a quarta semana $(p=0,001)$. Entretanto, não houve diferença significativa entre os grupos após a musicoterapia ${ }^{161}$.

Ressalta-se que, neste estudo, os participantes do grupo experimental puderam escolher as músicas que ouviriam - com o auxílio de um leitor de MP3 e fones de ouvido, por 45 minutos, uma vez por semana, durante quatro semanas - a partir de uma lista fornecida pelos pesquisadores, baseada em estudos locais anteriores, incluindo músicas meditativas, clássicas chinesas, clássicas ocidentais e jazz modernos ocidentais. $\mathrm{O}$ autor sugere que a utilização da música pela Enfermagem implica em um cuidado holístico e subsidia a construção de relações terapêuticas, evidenciando a musicoterapia como uma habilidade alternativa de autocuidado para melhorar a qualidade do sono e que deve ser encorajada pelos profissionais da saúde ${ }^{161}$.

A análise quantitativa de um ensaio clínico randomizado acerca dos efeitos da musicoterapia na espiritualidade - fé, paz e sentido na vida - de 17 pacientes de uma unidade de oncologia/hematologia dos Estados Unidos, evidenciou diferença significativa entre os grupos experimental e controle nos escores de fé e paz, com maior média no pós-teste do grupo experimental $(\mathrm{p}<0,05)$. Enfatiza-se que foram utilizadas de três a oito músicas, sugeridas pelos pesquisadores (Amazing Grace, por exemplo), após conhecerem os gêneros musicais de preferência dos participantes, executadas ao vivo (voz e violão), com duração de 15 a 30 minutos, durante três dias consecutivos ${ }^{162}$.

A análise qualitativa do discurso de quatro pacientes sugere que a musicoterapia melhora o estado de humor dos pacientes e os aproximam de Deus. Três dos quatro depoentes relataram que os hospitais poderiam subsidiar uma melhor assistência espiritual por meio da musicoterapia. Sugere-se que a música de preferência do paciente promove bem-estar espiritual e que o envolvimento ativo e o vínculo terapêutico podem servir como catalisadores para aumentar a espiritualidade ${ }^{162}$.

Os efeitos da música na dor também foram investigados em um ensaio clínico randomizado envolvendo 120 mulheres com câncer de mama após mastectomia radical, na China. Os pesquisadores forneceram uma seleção de 202 músicas, classificadas em quatro 
tipos - música popular chinesa clássica; música popular de outras culturas; música recomendada pela AAMT; e música chinesa para relaxamento - por três especialistas - um musicoterapeuta; um músico; e um oncologista - para que os participantes pudessem escolher as que ouviriam, com auxílio de um leitor de MP3 e fones de ouvido, durante 30 minutos, duas vezes por dia (manhã e noite) ${ }^{163}$.

Observou-se que todos os índices de dor no pós-teste - no dia anterior à alta hospitalar e nas duas readmissões hospitalares subsequentes para a quimioterapia - apresentaram melhora significativa em ambos os grupos em relação ao pré-teste (primeiro dia depois da cirurgia). Houve uma melhora significativa $(\mathrm{p}<0,001)$ no grupo experimental em relação ao grupo controle no primeiro pós-teste. Embora essa diferença entre os grupos tenha diminuído no terceiro pós-teste, ainda se manteve significativa $(\mathrm{p}<0,001)$. Os autores sugerem que a musicoterapia é um tratamento adjuvante viável e eficaz para o alívio da dor neste contexto ${ }^{163}$.

Nos cenários de cuidados paliativos, evidencia-se a revisão sistemática que objetivou avaliar estudos quantitativos e qualitativos sobre a experiência de pacientes com a música, de janeiro de 1990 a dezembro de 2010. Os resultados sugerem que a musicoterapia pode melhorar a qualidade de vida, aliviar os sintomas físicos, e fornecer apoio psicossocial para os pacientes. Porém, destaca-se o reduzido número de estudos incluídos (nove), em virtude da escassez de pesquisas neste contexto, sobretudo com bons delineamentos metodológicos ${ }^{164}$.

A eficácia de uma sessão de musicoterapia, associada com relaxamento autógeno guiado pelo terapeuta, para aliviar a dor de 200 pacientes internados sob cuidados paliativos, também foi avaliada por um ensaio clínico randomizado, nos Estados Unidos. Os resultados demonstraram alívio significativo da dor $(\mathrm{p}<0,001)$, no grupo experimental, observado por meio dos escores de três instrumentos (Escala Numérica de Dor ${ }^{165}$; Escala de Consolabilidade, Choro, Atividade, Pernas e Rosto ${ }^{166}$; Escala de Dor Funcional ${ }^{167-168}$.

A sessão de musicoterapia, que durava 20 minutos, iniciava ao som de um tambor do oceano ${ }^{\mathrm{i}}$, com exceções dos pacientes que expressaram aversão ao mesmo, e na sequência, para apoiar o relaxamento, introduzia-se a harpa, com improvisação no modo mixolídio em Sol maior, seguida de quatro peças na tonalidade de Dó maior, desconhecidas para a maioria dos ouvintes - Andante de Waddington (compasso binário); Passing By e Reverie de Grandjany (compassos binários); e Barcarolle de Grandjany (compasso ternário) - escolhidas com base na experiência clínica do musicoterapeuta e na descrição de outros pacientes, que as

'Instrumento musical de percussão que, quando manuseado em movimentos circulares, produz sons semelhantes às ondas do mar. 
consideravam tranquilas, pacíficas e calmantes. Os autores concluem que, no contexto estudado, este tipo de intervenção é eficaz no alívio da dor ${ }^{168}$.

Um ensaio clínico randomizado que avaliou a efetividade da música no alívio da dor em 126 pacientes com câncer, hospitalizados em Taiwan, constatou que oferecer, com auxílio de fones de ouvido, 30 minutos de músicas culturalmente apropriadas foi um elemento-chave. Os participantes tiveram a oportunidade de escolher, dentre as músicas pré-selecionado pelos pesquisadores, o tipo de música que acreditavam relaxá-los ou distraí-los melhor - canções folclóricas (43\%) e hinos budistas de Taiwan (28\%); e músicas ocidentais americanas, de harpa e piano (29\%). Os resultados revelaram maior alívio da dor oncológica em relação à analgesia e repouso na cama $(\mathrm{p}<0,001)$. Deste modo, os enfermeiros devem oferecer música calma e familiar para complementar a analgesia de pessoas com dor oncológica ${ }^{169}$.

Outro ensaio clínico randomizado realizado junto a 118 adolescentes que objetivou avaliar a utilidade de técnicas de distração musicais fáceis e práticas (com e sem fones de ouvido) na redução da dor durante a imunização contra a poliomielite em adolescentes, revelou que os grupos que receberam a intervenção - músicas relaxantes escolhidas por seis adolescentes que participaram do estudo piloto - eram menos propensos a relatar dor em relação ao grupo controle. Comparando as técnicas, eliminar os fones de ouvido emergiu como um preditor significativo de nenhuma dor. Os resultados sugerem que esta intervenção pode aliviar a dor e promover conforto durante procedimentos dolorosos como a imunização em adolescentes ${ }^{170}$.

Objetivando avaliar a redução da ansiedade em 100 pacientes submetidos à cirurgia de Mohs (tratamento do câncer de pele), um ensaio clínico randomizado constatou que ouvir música, gênero musical ou artista auto selecionado - durante 15 a 60 minutos, enquanto esperava o cirurgião e durante a primeira fase da cirurgia - reduziu significativamente $(\mathrm{p}<$ 0,001) a ansiedade dos pacientes, principalmente naqueles que fizeram a cirurgia pela primeira vez ${ }^{146}$.

Outro ensaio clínico randomizado acerca dos efeitos da musicoterapia na ansiedade de 120 mulheres com câncer de mama após mastectomia radical revelou que no pré-teste - no dia anterior à cirurgia - a maioria $(77,5 \%)$ das pacientes apresentavam um nível moderado de ansiedade e $15 \%$ um nível grave. Nas três mensurações pós-teste - no dia anterior à alta hospitalar e nas duas readmissões hospitalares subsequentes para a quimioterapia; após ouvirem, por 30 minutos, duas vezes por dia, as músicas que escolheram a partir de uma préseleção oferecida pelos pesquisadores - os níveis de ansiedade foram significativamente menores no grupo experimental, indicando que a musicoterapia exerce efeitos positivos nos 
níveis de ansiedade. $\mathrm{O}$ teste de interação $(\mathrm{p}=0,001)$ sugere que o efeito do tratamento aumenta com o tempo de seguimento ${ }^{171}$.

Estudo experimental transversal com pré e pós-teste foi realizado junto a 40 participantes com a finalidade de revelar os efeitos da musicoterapia associada com imagens visuais guiadas, sobre a ansiedade, náuseas e vômitos induzidos pela quimioterapia. Foram utilizados 60 minutos de músicas turcas instrumentais, serenas e suaves, por meio de reprodução musical, com auxílio de fones de ouvido, e cinco pinturas da natureza $(100 \mathrm{~cm} \times$ $200 \mathrm{~cm}$ ), como praia, floresta, lago e montanha, pradaria, céu e nuvens. Verificou-se que os níveis de ansiedade e, a intensidade e a duração das náuseas e vômitos reduziram significativamente $(\mathrm{p}<0,005)$. Os resultados sugerem que estas abordagens complementares têm efeito benéfico sobre a ansiedade, náuseas e vômitos induzidos pela quimioterapia, logo, devem ser implementadas nesse tipo de unidade. Os autores ainda reiteram a realização de programas de treinamento no ambiente de trabalho para aumentar o interesse e sensibilidade dos profissionais em relação a estas abordagens ${ }^{172}$.

A comparação entre a musicoterapia com a presença da Enfermagem e a musicoterapia com música gravada nos índices psicofisiológicos - amplitude de pulso do volume sanguíneo, frequência cardíaca, depressão, ansiedade e qualidade de sono - de 34 cuidadores de pacientes com câncer em um ensaio clínico randomizado do tipo crossover, demonstrou que em 30 minutos ambas apresentaram efeitos benéficos sobre a ansiedade, a depressão e a amplitude de pulso do volume sanguíneo ${ }^{173}$.

Foram utilizadas músicas japonesa (Prayer), chinesa (Spring Rural Field, Woman under the Moon), Taiwanesa (Destiny, Whispering Hope), Inglesa (Amazing Grace) e Checa (Going Home), executadas em um violino ou reproduzidas. Contudo, a musicoterapia com a presença da Enfermagem foi mais eficaz na redução da ansiedade e na qualidade do sono em comparação com a musicoterapia com música gravada $(\mathrm{p}<0,05)$. Todos os participantes relataram preferir a musicoterapia com a presença da Enfermagem, em detrimento da musicoterapia com música gravada, sugerindo uma experiência mais harmônica e amigável $^{173}$.

Ensaio clínico randomizado realizado em Taiwan objetivou determinar o efeito da musicoterapia e do relaxamento verbal no estado de ansiedade e na ansiedade induzida por manifestações fisiológicas em 98 pacientes com câncer antes e após a quimioterapia. Os pacientes do grupo experimental $(n=34)$ receberam uma única sessão de musicoterapia, baseada nas preferências musicais dos pacientes, com duração de uma hora. A musicoterapia estruturou-se da seguinte forma: período de preparação (10 minutos) - canções do Pacífico 
como Ambient Moods-Whale Song, incluindo o som das ondas do mar, aves marinhas e baleias; período de relaxamento profundo (12 minutos): meditação-relaxamento, por meio de instruções verbais gravadas para orientar o paciente: música ligeira, Forest Piano, que engloba sons da natureza, como o vento e aves, e o som do piano; e período de audição musical (38 minutos): Violin Rain e Aroma Lavender. Os pacientes do grupo de comparação $(\mathrm{n}=30)$ receberam 30 minutos de relaxamento guiado; e os pacientes do grupo controle $(\mathrm{n}=$ 34) receberam cuidados habituais ${ }^{174}$.

Os resultados evidenciaram que a música teve maior efeito positivo sobre a ansiedade pós-quimioterapia em relação aos outros grupos $(\mathrm{p}=0,005)$ e um aumento significativo na temperatura da pele. Os pacientes com alto estado de ansiedade no grupo experimental tiveram a maior queda da ansiedade pós-quimioterapia em relação aos que apresentaram estado de ansiedade normal. Os autores concluem que a musicoterapia e o relaxamento verbal são eficazes na redução da ansiedade induzida pela quimioterapia e que os enfermeiros oncologistas podem oferecer música e relaxamento verbal como intervenções adjuvantes para reduzir a dor e melhorar a qualidade da assistência ${ }^{174}$.

Vislumbrando avaliar o efeito da musicoterapia durante o repouso pós-operatório, um ensaio clínico randomizado realizado com 40 pacientes submetidos à cirurgia cardíaca (revascularização do miocárdio ou substituição de válvula aórtica) evidenciou que no grupo experimental os níveis de ocitocina, de relaxamento subjetivo e de pressão parcial de oxigênio no sangue $(\mathrm{PaO} 2)$ aumentaram significativamente em relação ao grupo controle ${ }^{175}$.

Os pacientes desse grupo experimental ouviram música, por meio de uma técnica de musicoterapia neurológica ${ }^{i i}$, que utiliza um travesseiro ligado a um leitor de MP3 para distribuir o som - Wellness Musicpillow - durante o repouso. Foram utilizadas músicas suaves, relaxantes, classificadas como MusiCure ${ }^{\circledR}$, com diferentes melodias, de 60 a 80 batimentos por minuto (bpm), durante 30 minutos. Os resultados sugerem a existência de uma relação causal entre as dimensões psicológica (música faz os pacientes se sentirem bem) e física (liberação de ocitocina), onde a música atua como uma fonte de suporte que aumenta o relaxamento e, portanto, deve ser oferecida como parte integrante do regime multimodal $\operatorname{administrado}^{175}$.

Vale destacar que a utilização da música no ambiente domiciliar de pessoas que convivem com o câncer e o fim da vida, pode avivar sensações agradáveis que contribuem

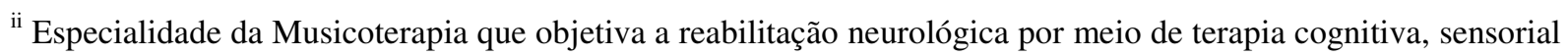
e motora.
} 
para o conforto e bem-estar do doente e sua família, dando sentido aos seus dias; suscita sentimentos de alegria, tornando-os mais comunicativos, como se a doença parasse no tempo e no espaço vivido; representa um suporte de apoio psicossocioespiritual que desperta força e coragem para transcenderem a angústia de sua condição existencial ${ }^{1}$.

Com efeito, a música integra os diferentes ciclos da vida, desde a concepção até a morte $^{176}$. Ao se constituir como expressão artística e cultural universal, produz trilhas sonoras que embalam o cotidiano da vida social, afetiva e profissional das pessoas ${ }^{177}$. Na infância, destacam-se as cantigas de ninar e de roda, e na adolescência, a tendência é influenciada pela mídia. Na fase adulta, as escolhas geralmente estão relacionadas ao estado emocional, subsistindo até a velhice, fase em que a preferência musical reporta-se ao passado, evocando recordações de outrora ${ }^{176}$.

Salienta-se que em 1977, o Royal Victoria Hospital iniciou um programa de musicoterapia em seu serviço de cuidados paliativos em Montreal, objetivando contemplar as necessidades de pacientes em estágio terminal e seus familiares, e evidenciar a importância deste recurso até então subutilizado ${ }^{145}$. Em um estudo de revisão bibliográfica constatou-se que, quando utilizada com competência e sensibilidade para subsidiar a qualidade de vida, a humanização do cuidado e a expressão de afetividade, por vezes ignorada ante a iminência de morte, a música reverencia os pressupostos filosóficos dos cuidados paliativos ${ }^{16}$.

Os momentos de silêncio, tão difíceis de suportar quando se acompanha o fim da vida de alguém, podem ser preenchidos com a beleza e o significado provenientes da música, tornando o ambiente mais confortável. A suavidade das canções de ninar traduz sensação de cuidado e proteção, podendo aliviar o temor de ser abandonado durante o processo de finitude ${ }^{178}$.

Enquanto recurso de comunicação, a música pode facilitar o encontro entre o ser que propõe a intervenção e o ser que a recebe ou compartilha, estabelecendo uma comunhão, um estar junto, permitindo que ambos usufruam dos benefícios que ela encerra em si mesma. "Em um encontro mediado pela música, a comunicação não verbal é aquela que normalmente prevalece" $^{, 179: 131}$.

Torna-se imprescindível que a Enfermagem reconheça a unicidade, a complexidade e a multidimensionalidade de cada paciente, dispondo os recursos em comunicação (verbal e não verbal) necessários para percebê-lo e compreendê-lo em sua integridade, e disponibilize um cuidado integral e humanizado ${ }^{180}$. Seguindo este pensar, 
[...] escutar não é apenas ouvir, mas permanecer em silêncio, utilizar gestos de afeto e sorriso que expressem aceitação e estimulem a expressão de sentimentos. Perceber constitui não apenas olhar, mas atentar e identificar as diferentes dimensões do outro, por meio de suas experiências, comportamentos, emoções e espiritualidade $^{180: 673}$.

Nesse contexto, a Tanatomusicologia emerge como uma sub-especialidade em cuidados paliativos, uma modalidade clínica/musical que articula música e cuidado no fim da vida. Com o intuito de contemplar as necessidades físicas, emocionais e espirituais do paciente e seus familiares, o profissional tanatomusicologista utiliza harpa e voz à beira do leito, e oferece músicas prescritivas, ou seja, música ao vivo, adaptadas à especificidade de cada situação, em consonância com os parâmetros fisiológicos do paciente (dor, ansiedade e agitação, alteração do nível de consciência, da frequência cardíaca ou do padrão respiratório) $^{181}$.

Idealizada por Therese Schroeder-Sheker - musicista, educadora e médica - a Tanatomusicologia tem sido implementada nos Estados Unidos e outros países, para aliviar a dor, a inquietação, a insônia e a dispnéia, bem como a raiva, a tristeza e o medo, onde a música representa uma expressão da beleza e do amor, transcendendo afiliações diversas de fé e cultura. Embora não disponha de um repertório específico, orienta-se a utilização de músicas calmas, tranquilas e meditativas, como as músicas sacras (canto gregoriano, hinos, orações e cânticos de louvor), canções de ninar e outras formas tradicionais ${ }^{181}$.

Diante do exposto, as possibilidades de utilizar a música no cuidado de Enfermagem são abrangentes e a incipiência acerca de seus efeitos terapêuticos, sobretudo na dimensão espiritual de familiares sob cuidados paliativos, nos impulsiona a pesquisar com o intuito de contribuir para o conhecimento nessa área e estabelecer critérios de utilização confiáveis na prática clínica $^{144}$.

\subsection{TEORIAS DE ENFERMAGEM E CUIDADOS PALIATIVOS}

Para delinear um conceito de Enfermagem em cuidados paliativos, torna-se imprescindível resgatar as bases conceituais das teorias de Enfermagem e identificar as que mais se aproximam dos pressupostos filosóficos dos cuidados paliativos ${ }^{182}$. Nessa perspectiva, serão apresentadas algumas breves reflexões que evidenciam esta aproximação.

Embora enfatizasse a individualidade do cuidado e a recuperação da vitalidade do ser doente em detrimento do cuidado no processo de morte e morrer, a Teoria Ambientalista de 
Florence Nightingale ${ }^{183}$ preconizava o bem-estar e a dignidade humana. Seu pressuposto de que o ambiente interfere na qualidade do cuidado, converge com a filosofia paliativista ao proporcionar um ambiente agradável, favorecendo uma morte digna. Nesse contexto, "a busca deve ser por um ambiente mais familiar possível para que a morte aconteça com a presença dos entes queridos, sempre que possível"182:11.

A Teoria do Cuidado Transpessoal de Jean Watson ${ }^{184}$ concebe a Enfermagem como uma ciência humana cuja arte de cuidar contribui para a manutenção da vida, bem como uma filosofia - dinâmica e evolutiva - que sugere ternura e distintas significações. Sua versatilidade vem de encontro com os pressupostos dos cuidados paliativos de reafirmar a vida e articular todas as dimensões humanas - especialmente a dimensão espiritual, tão negligenciada pelos profissionais da saúde - no cuidado ao paciente/família, subsidiando o suporte necessário para ajudá-los a viver ativamente até a morte, respeitando suas $\operatorname{limitações~}^{182}$.

Dorothea Orem defende a Teoria do Déficit do Autocuidado ${ }^{185}$ partindo do pressuposto de que o autocuidado é uma habilidade prática autobeneficente que subsidia o aprimoramento e o crescimento do ser humano, objetivando o bem-estar, a preservação da vida e sua funcionalidade, ou a dignidade no processo de morte e morrer. Sua compatibilidade com a filosofia paliativista evidencia-se no princípio de que os cuidados paliativos devem ser implementados e, gradativamente, intensificados de acordo com o grau de dependência do paciente ou da unidade social (família ou grupos) para o autocuidado e, consequentemente, do seu grau de dependência dos cuidados de Enfermagem ${ }^{182}$.

$\mathrm{Na}$ Teoria do Conforto, Katharine Kolcaba ${ }^{186}$ focaliza a relevância do "Conforto de Alívio", ou seja, do cuidado para aliviar a dor física, haja vista que o "Conforto de Tranquilidade", inerente ao alívio da dor psicoemocional e à experiência de paz e tranquilidade interior, só é alcançado mediante o alívio da dor física, extremamente significativa para pacientes/famílias sob cuidados paliativos. Quando o paciente/família encontra-se em paz consigo mesmo e com aqueles que o rodeiam, experiencia o "Conforto de Transcendência", relacionado ao alívio da dor social e espiritual, ao alcance da dignidade pessoal proveniente da integralidade do cuidado. Os desígnios dessa teoria confluem com o conceito de dor total - retromencionado - instituído por Cicely Saunders ${ }^{182}$.

Compreender a universalidade das experiências humanas, sobretudo a morte e o morrer, é uma das reflexões propostas por Rosemarie Rizzo Parse em sua Teoria do Tornar-se Humano $^{187}$. O princípio da transcendência, por ela abordado, transmite a ideia de autotranscendência resultante do desejo do paciente ou da família receber o cuidado, e do 
enfermeiro agregar a subjetividade inerente à experiência do cuidar. Nesse contexto, o vínculo estabelecido no processo do cuidar possibilita a descoberta do sentido da vida para os participantes envolvidos e uma morte com dignidade para quem está se despedindo da vida ${ }^{182}$.

Concernente à Teoria das Necessidades Fundamentais de Virgínia Henderson ${ }^{188}$, destaca-se sua intencionalidade de contemplar todas as dimensões humanas no cuidado de Enfermagem, bem como sua inquietação com o fenômeno morte. Sua definição de Enfermagem é reverenciada como uma das mais completas e, por defender a morte com dignidade, possivelmente seja a que mais se aproxima dos pressupostos filosóficos dos cuidados paliativos $^{182}$.

Para finalizar, a Teoria da Adaptação de Callista Roy ${ }^{189}$, que será adotada como referencial teórico deste estudo. O Modelo de Adaptação de Roy foi criado em 1964 e integra o grupo de Teorias de Enfermagem baseadas no processo interativo, onde o ser humano é reverenciado como um ser holístico que interage constantemente com outros seres humanos e com o ambiente, e que se adapta às situações que vêm ao seu encontro ${ }^{190}$.

Irmã Callista Roy nasceu em 04 de outubro de 1939, é membro do Sisters of Saint Joseph of Carondelet, graduada em Ciência da Enfermagem pela Mount Saint Mary's College, em Los Angeles, Califórnia, mestre em Ciência pela University of California at Los Angeles (UCLA), mestre e doutora em Sociologia pela UCLA. Atualmente é docente na Boston College, School of Nursing ${ }^{190}$. Os quatro pilares - pessoa, ambiente, saúde e Enfermagem - que norteiam as bases conceituais de sua teoria, são apresentados a seguir, para subsidiar melhor compreensão da inter-relação entre os cuidados ao familiar enlutado e os cuidados paliativos. Na perspectiva de Roy, a pessoa é considerada como um sistema adaptativo formado pelos seguintes elementos: input, constituído pelos estímulos internos e externos (focais, contextuais e residuais) responsáveis pelo estabelecimento dos níveis de adaptação da pessoa às mudanças ambientais; output, que abrange respostas, controles e estratégias de enfrentamento; e feedback, que representa sua retroalimentação, e se encontra atrelado aos subsistemas regulador e cognoscente ${ }^{191}$.

O subsistema regulador apreende os estímulos internos e produz respostas automáticas e inconscientes por meio dos sistemas químico, neuronal e endócrino. Por outro lado, o subsistema cognoscente processa estímulos internos e externos, cujas respostas, conscientes e deliberadas, estão vinculadas às funções cognitivas e intelectuais ${ }^{191}$. Esses subsistemas podem ser identificados em pacientes sob cuidados paliativos, diante da necessidade de adaptação às alterações, fisiológicas e/ou cognitivas, emergentes ${ }^{182}$. 
No que tange ao input, os estímulos focais são aqueles com os quais a pessoa se confronta diretamente; os contextuais são estímulos que, indiretamente, influenciam positiva ou negativamente a situação; e os residuais são estímulos intrínsecos ou não à pessoa, cuja influência nas respostas adaptativas não está claramente definida ${ }^{191}$.

O ambiente compreende todas as condições, circunstâncias e influências que circundam e afetam a evolução e o comportamento da pessoa. A saúde é um processo que subsidia a integridade e a capacidade de sobrevivência, crescimento, reprodução e controle da pessoa. A Enfermagem, por sua vez, manipula os estímulos focais, contextuais e residuais para promover respostas adaptativas em relação aos quatro modos adaptativos: fisiológico, autoconceito, função do papel e interdependência ${ }^{191}$.

O modo fisiológico compreende as respostas físicas aos estímulos ambientais e envolve o subsistema regulador ${ }^{191}$. Neste modo, evidencia-se a intencionalidade de cuidar do enfermeiro, por meio de intervenções dependentes da interdisciplinaridade, objetivando suprir, especialmente, as necessidades biológicas emergentes - controle dos sintomas - sem, contudo, negligenciar as demais dimensões do cuidado ${ }^{182}$.

$\mathrm{O}$ autoconceito está relacionado à integridade física e aos aspectos psicológicos e espirituais, e o modo função do papel abrange a dimensão social e as vertentes subjacentes ao papel desempenhado ${ }^{191}$. Estes se reportam à interação - relacionamento interpessoal - do paciente com a família e a comunidade, contemplando a dimensão social do cuidado ${ }^{182}$.

Contextualizando os modos supracitados com os estágios exacerbados no fim da vida descritos por Kübler-Ross ${ }^{35}$, é possível compreender a dificuldade do paciente em aceitar a morte - negação - a raiva que descarrega sobre aqueles que o cercam e a depressão que resulta em isolamento social, e, consequentemente, ajudá-lo em sua transcendência ${ }^{182}$. O modo da interdependência é onde as necessidades afetivas são supridas ${ }^{191}$. Quando o paciente alcança o estágio de aceitação, resignifica sua vida e experiencia a integralidade relacional defendida por Roy ${ }^{182}$.

Para Tomey e Alligood apud Silva e Silva ${ }^{182}$, outro conceito relevante na teoria de Roy é o processo coping (enfrentamento), que abrange os mecanismos inatos e adquiridos de interação - adaptação - com o ambiente em transformação. Ressalta-se a importância de a equipe de Enfermagem desenvolver habilidade cognitiva e relacional na interação com o paciente e sua família, amparando-a no enfrentamento das adversidades que emergem quando os limites da vida se estabelecem.

O coping inato é definido como uma característica genética da espécie humana e, portanto, encarado como um mecanismo instintivo, que dispensa reflexões prévias. O coping 
adquirido, por sua vez, constitui uma habilidade desenvolvida no âmbito das experiências cotidianas, que influencia as respostas adaptativas a estímulos específicos. Os pacientes sob cuidados paliativos comumente compartilham o aprendizado, o crescimento pessoal e espiritual extraído de suas vivências ao confrontar uma doença sem possibilidades de cura e a morte $^{182}$. Nessa perspectiva, define-se Enfermagem em cuidados paliativos como

uma disciplina que alia a arte e ciência do cuidar em prol de um cuidado à pessoa que se encontra em processo de morte e morrer e sua família no processo de luto; disciplina que, desenvolvida pela equipe de enfermagem atuante no contexto de uma equipe interdisciplinar de cuidados paliativos, direciona-se pelo foco do cuidar/cuidado nas dimensões biopsicossocioespiritual e cultural - cuidado integral e relacional ${ }^{182: 26}$.

Com efeito, a Teoria da Adaptação de Callista Roy ${ }^{189}$ converge com o Modelo do Processo Dual ${ }^{79}$, evidenciando o processo de luto como um enfrentamento adaptativo que confronta ou evita a perda, de acordo com as necessidades de restauração da pessoa enlutada. Diante do exposto, idealizou-se como proposta de Tese, utilizar a música como recurso terapêutico - estímulo contextual - que pode influenciar positivamente as respostas adaptativas no cuidado de enfermagem à família enlutada, ponderando que a morte de um ente querido constitui um estímulo focal confrontado pelos familiares. 
Se a vida é desventura, por que vivê-la? Eis a posição humana, oh! Lua imaculada! Mas, tu não és mortal, por isso não te importas, talvez, da minha queixa.

No entanto, eterna e solitária peregrina, que tão pensativa és, tu, talvez, compreendas esta vida terrena, o nosso sofrimento, a nossa angústia, a nossa morte, o nosso perecer, este supremo desfalecimento do semblante ao findar na terra e ter que abandonar as pessoas amadas. Tu, certamente, compreendes o porquê das coisas, e vês a razão de tudo, desde a manhã à noite, no silencioso e infinito rolar do tempo.

Giacomo Leopardi

\section{HIPÓTESES}




\section{HIPÓTESES}

H0 : $_{1}$ os familiares enlutados que ouvem música sacra ao vivo não apresentam melhores níveis de bem-estar espiritual em relação aos familiares enlutados que não o fazem.

H1 1 : os familiares enlutados que ouvem música sacra ao vivo apresentam melhores níveis de bem-estar espiritual em relação aos familiares enlutados que não o fazem.

$\mathbf{H 0}_{2}$ : os familiares enlutados que ouvem música sacra cantada ao vivo não apresentam melhores níveis de bem-estar espiritual quando comparado aos familiares enlutados que ouvem música sacra instrumental ao vivo.

H12: os familiares enlutados que ouvem música sacra cantada ao vivo apresentam melhores níveis de bem-estar espiritual quando comparado aos familiares enlutados que ouvem música sacra instrumental ao vivo.

H0 $_{3}$ : não há correlação entre o nível de bem-estar espiritual e as variáveis sociodemográficas, as relacionadas à crença religiosa, às experiências sonoro-musicais pregressas, aos fatores intervenientes no processo de elaboração do luto, aos sentimentos evidenciados e à apreciação estética após a intervenção.

H1 3 : há correlação entre o nível de bem-estar espiritual e as variáveis sociodemográficas, as relacionadas à crença religiosa, às experiências sonoro-musicais pregressas, aos fatores intervenientes no processo de elaboração do luto, aos sentimentos evidenciados e à apreciação estética após a intervenção. 
Não devo insistir sobre os efeitos psíquicos e fisiológicos da música, mais que suficientemente provados pela experiência de cada um, pela tradição e pela ciência. De resto, negar esses poderes, seria negar a própria função dos sentidos [...]. Donde lhe vem o seu extraordinário poder de atuação sobre o indivíduo e sobre as massas?

A meu ver, de duas coisas essenciais: da força contundente de seu ritmo, e da indestinação intelectual do seu som. Mário de Andrade 


\section{MÉTODO}

\subsection{TIPO DE ESTUDO}

Trata-se de um Ensaio Clínico Randomizado (ECR), com abordagem quantitativa. Um ECR destina-se a avaliar intervenções clínicas com distribuição aleatória do tratamento, sob condições altamente controladas. Um delineamento experimental caracteriza-se pelas seguintes propriedades ${ }^{192}$ :

- Manipulação - o pesquisador realmente faz alguma coisa a alguns participantes, ou seja, há algum tipo de intervenção. A Variável Independente (VI) é manipulada, administrando-se um tratamento experimental ou intervenção a alguns participantes e não o administrando a outros, e observa o efeito disso sobre a Variável Dependente (VD). No presente estudo, a musicoterapia representará a VI, e o bem-estar espiritual, a VD.

- Controle - o pesquisador introduz controles no estudo, incluindo o delineamento de uma boa estimativa de um contrafato, como base de comparação - comumente um grupo de controle que não recebe a intervenção, ou seja, um conjunto de participantes cujo desempenho em relação a uma VD é usado para avaliar a performance do grupo experimental (aquele que recebe a intervenção) em relação a essa mesma variável.

- Randomização (atribuição randômica) - o pesquisador distribui os participantes nos grupos de controle ou experimental de modo aleatório. Cada participante tem chances iguais de ser incluído nos grupos, evitando desvios sistemáticos nos grupos, relativo a atributos que podem afetar a VD. Espera-se que os grupos, assim formados, sejam comparáveis, em média, em termos de uma série de traços biológicos, psicológicos e sociais logo no início do estudo.

Os participantes foram alocados, aleatoriamente, em três grupos, sendo um grupo controle - sem intervenção, ou seja, sem música (Grupo 1) e dois grupos experimentais - um com música sacra cantada (Grupo 2) e outro com música sacra instrumental, ou seja, música sem letra (Grupo 3). Após o sorteio do grupo para o primeiro participante, que coincidentemente foi o Grupo 1, os demais foram alocados um para cada grupo, na sequência Grupo 2, Grupo 3, Grupo 1, e assim sucessivamente. Ressalta-se que, em alguns casos, a família foi randomizada, ou seja, participantes que integravam a mesma família, tiveram a oportunidade de receber a mesma intervenção, em grupo. 


\subsection{LOCAL}

A pesquisa foi realizada no ambiente domiciliar de usuários (famílias) cadastrados na Rede Feminina de Combate ao Câncer - RFCC de Maringá-PR ${ }^{193}$. Trata-se de uma Organização Social sem fins lucrativos, fundada em 1983, que atende diretamente usuários do Sistema Único de Saúde (SUS) - pacientes com câncer - jovem, adulto ou idoso, residente em Maringá-PR, Sarandi-PR e Paiçandu-PR, em situação de vulnerabilidade social; criança ou adolescente residente em Maringá ou cidades pertencentes a 15 a Regional de Saúde, comprovadamente sem condições financeiras, disponibilizando os serviços de fisioterapia, psicologia, farmácia, assistência social e assessoria jurídica.

Os usuários cadastrados recebem mensalmente cestas básicas, leite, fraldas descartáveis e medicamentos de acordo com suas necessidades, além de visitas domiciliares para o acompanhamento da evolução de seu tratamento, realizadas pelo serviço de voluntariado. Em parceria com Instituições de Ensino Superior (IES) de Maringá, a RFCC oportuniza aos acadêmicos de enfermagem e outros cursos da área da saúde, inseridos em projetos de extensão universitária, o contato com seus usuários.

A casa de apoio da RFCC, por sua vez, acolhe aproximadamente 25 usuários por mês, adultos de ambos os sexos que realizam tratamento fora do domicílio (TFD), ou seja, pacientes oriundos de outros municípios e estados, que fazem quimioterapia e/ou radioterapia em Maringá, oferecendo os serviços de hotelaria (pouso, banho e alimentação) e transporte gratuitos para a clínica ou hospital. Independentemente do quadro clínico do paciente, a presença de um acompanhante é permitida, mas não obrigatória.

$\mathrm{O}$ projeto de pesquisa foi apresentado à diretora da RFCC de Maringá que autorizou sua realização, reconhecendo sua importância para a comunidade científica e toda sociedade (Anexo 1).

\subsection{AMOSTRA}

O cálculo amostral foi feito a partir do próprio banco de dados, ou seja, quando o pesquisador já havia coletado dados de 30 participantes, o banco de dados foi utilizado como estudo piloto, para estimar a amostra necessária para que diferença observada fosse significativa $(\mathrm{N}=69)$, com confiança e poder de $95 \%$ cada, assumindo que o tamanho de efeito se mantivesse ou fosse maior. 
A amostra foi composta por familiares enlutados que contemplaram os seguintes critérios de inclusão:

- estar enlutado pela morte de um ente querido (pai, mãe ou cônjuge), cadastrado na RFCC de Maringá-PR, cujo óbito tenha ocorrido por câncer, há pelo menos um mês e no máximo 12 meses. Ressalta-se que ambas as relações afetivas constituem fatores para TLP ${ }^{84}$;

- ter participado do processo de cuidado no fim da vida de seu ente querido;

- residir nos municípios de Maringá-PR, Sarandi-PR ou Paiçandu-PR;

- ter idade igual ou superior a 18 anos;

- ter função auditiva referida preservada;

- ter a função da linguagem preservada para responder à Escala de Bem-Estar Espiritual (EBE) (Anexo 2) e um formulário semiestruturado (Apêndice A).

Os critérios de exclusão foram:

- familiares que mudassem de cidade durante a coleta de dados;

- familiares que apresentassem dificuldade auditiva no decorrer da coleta de dados;

- familiares que apresentassem, no decorrer da coleta de dados, dificuldade cognitiva para expressar suas percepções;

- familiares que vivenciam a perda de outro familiar durante o período de coleta de dados.

No total, 169 familiares enlutados foram avaliados para elegibilidade, mas 60 familiares não atenderam aos critérios de inclusão, pelas seguintes razões:

- 33 não aceitaram participar da pesquisa, sendo que um participou como ouvinte, acompanhando uma filha, e um influenciou a decisão de sete filhos;

- 13 eram solteiros, viúvos, ou não tinham filhos, dos quais um, após solicitar a visita durante o contato telefônico, recebeu a intervenção (uma sessão);

- oito mudaram de cidade logo após a morte do ente querido;

- três não participaram porque o tempo expirou, um por indisponibilidade de tempo para agendar a visita, e dois porque o registro de morte do ente querido na RFCC foi tardio;

- dois porque os entes queridos morreram por outra causa (acidente automobilístico);

- um porque não participou do processo de cuidado de seu ente querido. 
Cinco familiares desistiram de participar do estudo antes do segundo encontro, ou seja, antes de receber a intervenção e outros 30 familiares deixaram de ser randomizados por outras razões:

- 10 não foram contatados por residirem em outro endereço, por não terem participado do processo de cuidado de seu ente querido ou pela indisponibilidade de tempo, referida pelos próprios participantes, ou pelo fato destes acreditarem que a intervenção proposta não faria bem para o outro familiar naquele momento, desestimulando a visita;

- sete não tinham disponibilidade de tempo para agendar a visita;

- sete não foram encontrados;

- três aceitaram participar, mas não participaram por indisponibilidade de tempo para agendar as visitas subsequentes;

- um aceitou, mas não foi encontrado;

- um porque chegou à casa de sua filha, no momento em que ela recebia a primeira sessão musical e permaneceu até o término da mesma;

- um morreu antes do segundo encontro.

Deste modo, 74 familiares enlutados foram randomizados e alocados, respectivamente, no Grupo $1(\mathrm{n}=25)$, no Grupo $2(\mathrm{n}=23)$ e no Grupo $3(\mathrm{n}=26)$. Contudo, houve uma perda de seguimento de três familiares, por indisponibilidade de tempo para agendar as visitas subsequentes para a conclusão da coleta de dados, sendo um do Grupo 1 e dois do Grupo 3; e a exclusão de dois participantes, por serem filhos adotivos (um do Grupo 1 e um do Grupo 3), na tentativa de padronizar a amostra, considerando o delineamento do estudo. Logo, apenas 69 familiares enlutados foram participantes efetivos, conforme representado na figura 2. 


\section{Inclusão}

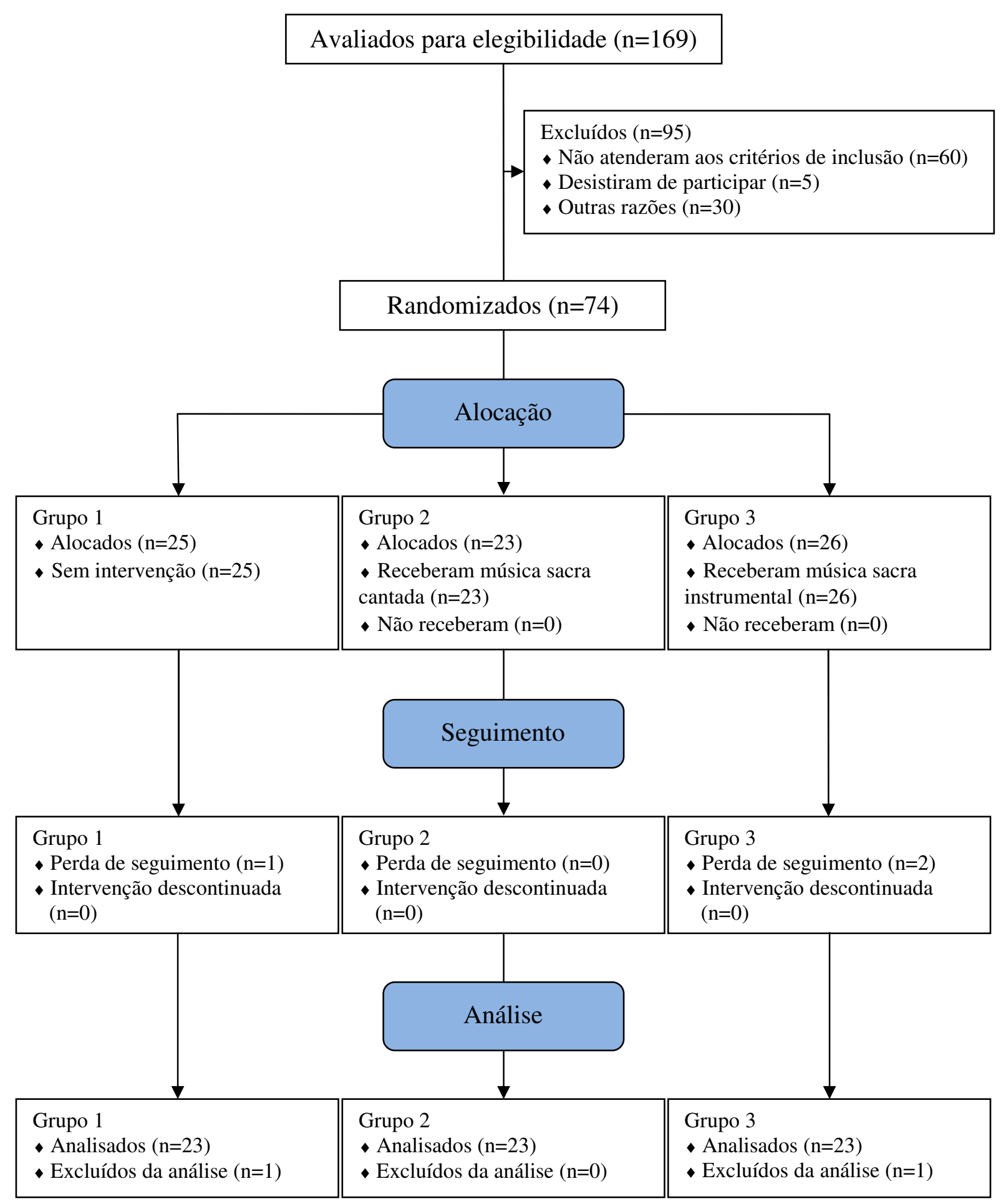

Figura 2. Fluxograma de inclusão e exclusão dos participantes: adaptado do CONSORT 2010 Flow Diagram ${ }^{\text {iii }}$. Maringá, PR, Brasil, 2015.

iii Consolidated Standards of Reporting Trials. CONSORT 2010 Flow Diagram. [cited 2015 dez 26]. Available from: http://www.consort-statement.org/. 


\subsection{INSTRUMENTOS}

\subsubsection{Formulário semiestruturado}

Baseado em instrumentos utilizados em outros estudos, elaborou-se o formulário semiestruturado que abrange variáveis sociodemográficas e variáveis relacionadas à crença religiosa $^{194}$, às experiências sonoro-musicais ${ }^{195}$, aos fatores intervenientes no processo de elaboração do luto ${ }^{50}$, além da apreciação estética dos participantes e os sentimentos evidenciados após a intervenção.

\subsubsection{Escala de Bem-Estar Espiritual (EBE)}

Considerada padrão de referência para o delineamento de instrumentos de mensuração e avaliação do fenômeno espiritualidade, a EBE (Spiritual Well-Being Scale - SWBS) (Anexo 2) foi elaborada por Paloutzian e Ellison em $1982^{196}$, adaptada e validada para a população brasileira $^{197}$. Trata-se de uma escala do tipo Likert, de seis pontos: Concordo Totalmente (CT), Concordo mais que discordo (Cd), Concordo Parcialmente (CP), Discordo Parcialmente (DP), Discordo mais que concordo (Dc), e Discordo Totalmente (DT).

É composta por 20 itens dispostos proporcionalmente em duas subescalas. Um delas avalia o Bem-Estar Religioso (BER) - dimensão vertical da espiritualidade - que contém uma referência a Deus e está relacionado à satisfação na conexão (comunhão e relação pessoal íntima) com Ele ou com algo que se considere como uma força superior, que transcende as dimensões humanas, algo sagrado, e que tem sido associado positivamente com força interior (desafio, compromisso e controle) e esperança, e negativamente com depressão e solidão ${ }^{197}$.

A outra subescala avalia o Bem-Estar Existencial (BEE) - dimensão horizontal da espiritualidade - que se refere à percepção em relação ao sentido e significado da vida independente de uma referência religiosa ${ }^{197}$. Destarte, para evitar possíveis desconfortos, antes de responder a EBE os participantes foram orientados a substituir a palavra "Deus" por qualquer outra relacionada à sua espiritualidade, religiosidade ou crença religiosa, de modo que se sintam confortáveis ao respondê-la.

Os itens com conotação positiva $(3,4,7,8,10,11,14,15,17,19,20)$ têm sua pontuação somada da seguinte maneira: $\mathrm{CT}=6, \mathrm{Cd}=5, \mathrm{CP}=4, \mathrm{DP}=3, \mathrm{Dc}=2$ e $\mathrm{DT}=1$. Os demais itens têm conotação negativa e devem ser somados de forma invertida: $\mathrm{CT}=1, \mathrm{Cd}=2, \mathrm{CP}=3$, $\mathrm{DP}=4, \mathrm{Dc}=5$ e $\mathrm{DT}=6$. $\mathrm{O}$ escore geral resulta da soma dos escores das duas subescalas e pode 
variar de 20 a $120^{197}$. Sugere-se como pontos de corte para o escore geral os intervalos de 20 a 40, 41 a 99 e 100 a 120 para bem-estar espiritual baixo, moderado e alto, respectivamente. Os escores altos são considerados como bem-estar espiritual positivo e os escores baixos e moderados como bem-estar espiritual negativo. Nas duas subescalas, os intervalos são de 10 a 20, 21 a 49 e 50 a 60 pontos para bem-estar espiritual baixo, moderado e alto, respectivamente ${ }^{196}$.

A $\mathrm{EBE}^{197}$ tem sido utilizada em diversos contextos, para avaliar as repercussões psicossociais, apoio social e bem-estar espiritual em mulheres com câncer de mama ${ }^{198}$; o bem-estar espiritual e os transtornos psiquiátricos menores em estudantes de psicologia ${ }^{199}$; a relação entre bem-estar espiritual e transtornos psiquiátricos menores em estudantes de medicina e direito ${ }^{111}$; a qualidade de vida e o bem-estar espiritual em pacientes com doença pulmonar obstrutiva crônica ${ }^{200}$; a saúde e o bem-estar espiritual em adultos portoalegrenses ${ }^{201}$; a eficácia de diferentes instrumentos para a atribuição do diagnóstico de enfermagem sofrimento espiritual ${ }^{194}$; a qualidade de vida e o bem-estar espiritual em pessoas vivendo com o Human Immunodeficiency Virus (HIV)/Aids ${ }^{202}$; o enfermeiro frente à questão da espiritualidade 203 ; o bem-estar espiritual e Síndrome de Burnout em psicólogos de hospitais públicos de João Pessoa/PB ${ }^{204}$.

\subsection{PROCEDIMENTOS DE COLETA DE DADOS}

A coleta de dados ocorreu durante 15 meses (de janeiro de 2014 a março de 2015) e foi realizada de acordo com a descrição a seguir:

- $1^{\circ}$ encontro: Após aprovação do projeto de pesquisa pelo Comitê de Ética e Pesquisa da EEUSP, Parecer 489.976 (Anexo 3), já tendo o consentimento da diretora da RFCC, bem como os nomes e respectivos contatos (telefone e endereço) dos usuários cadastrados, os familiares enlutados foram contatados pessoalmente pelo pesquisador que, além de apresentar o seu vínculo acadêmico, se identificou como o enfermeiro que estava realizando visitas às famílias enlutadas em nome da RFCC, organização social com a qual tinha um vínculo previamente estabelecido e era responsável por fornecer os seus dados pessoais.

Assim como nos encontros subsequentes, a abordagem inicial do pesquisador no primeiro encontro foi focada na questão da perda. Na sequência, o pesquisador introduziu, sucintamente, o motivo de sua visita, dizendo que estava realizando uma pesquisa com familiares enlutados, explicando os seus objetivos, os critérios de inclusão e exclusão, as 
etapas da intervenção musical e da coleta de dados. Neste momento, os familiares foram convidados a participar da pesquisa e, quando demonstravam interesse e contemplavam os critérios de inclusão, eram agendados os encontros subsequentes.

Nos grupos experimentais, os quatro encontros subsequentes foram agendados com intervalos de uma semana, em local, dia da semana e horário previamente estabelecido em consonância com a disponibilidade dos participantes e do pesquisador. No grupo controle, foram agendados apenas dois encontros subsequentes, sendo um com intervalo de uma semana e outro, com intervalo de um mês, em local, dia da semana e horário previamente estabelecido em consonância com a disponibilidade dos participantes e do pesquisador. $\mathrm{O}$ intervalo de um mês foi estabelecido para evitar que a presença semanal do pesquisador interferisse nos desfechos, haja vista que a simples presença do enfermeiro poderia representar, e de fato representa, um suporte emocional, que transmite conforto e, consequentemente, poderia influenciar a percepção dos participantes, em relação ao bem-estar espiritual.

- $2^{\text {o }}$ encontro: Inicialmente o pesquisador perguntava ao participante como ele havia passado desde o último encontro e confirmava o seu interesse em participar da pesquisa, procedendo à leitura e assinatura de duas vias do Termo de Consentimento Livre e Esclarecido (TCLE) (Apêndice B), em conformidade com os aspectos éticos disciplinados pela Resolução No 466, de 12 de dezembro de 2012, do CNS-MS ${ }^{205}$. Logo após, o participante respondia ao formulário semiestruturado e à EBE. Em seguida, o pesquisador confirmava o encontro subsequente, com intervalo de um mês, com os participantes alocados para o grupo controle, para a reaplicação da EBE, e orientava os participantes alocados para os grupos experimentais a se posicionarem confortavelmente para dar início à intervenção musical. Ao término da intervenção musical eram confirmados a data, o local e o horário do encontro subsequente.

- $3^{\circ}$ encontro: Inicialmente o pesquisador perguntava ao participante como ele passou desde o último encontro e se certificava sobre o seu interesse em continuar participando da pesquisa. Posteriormente, o pesquisador orientava o participante a se posicionar confortavelmente para dar início à intervenção musical. Ao término da intervenção musical eram confirmados a data, o local e o horário do encontro subsequente.

- $4^{\mathrm{o}}$ encontro: Inicialmente o pesquisador perguntava ao participante como ele havia passado desde o último encontro e se podia prosseguir com a intervenção musical. Posteriormente, o pesquisador orientava o participante a se posicionar confortavelmente para 
dar início à intervenção musical. Ao término da intervenção musical eram confirmados a data, o local e o horário do último encontro.

- $5^{\circ}$ encontro: Inicialmente o pesquisador perguntava ao participante como ele havia passado desde o último encontro e confirmava o seu consentimento em participar da última sessão musical e responder novamente a EBE. Posteriormente, o pesquisador orientava o participante a se posicionar confortavelmente para dar início à intervenção musical.

Ao término da intervenção musical era reaplicada a EBE, e o pesquisador perguntava como o participante havia se sentido ao ouvir música sacra, qual das três músicas gostou mais de ouvir, e quais as razões de sua escolha (sendo estas informações registradas no formulário de identificação do participante). No momento da despedida os participantes foram lembrados de que no TCLE tinha os contatos dos responsáveis pela pesquisa e do Comitê de Ética em Pesquisa da EEUSP, caso fosse necessário, ficando o pesquisador à sua disposição para eventuais questionamentos.

Todos os familiares enlutados foram convidados a participar da pesquisa, contudo nas famílias em que existiram mais de um familiar interessado e que contemplasse os critérios de inclusão, a coleta de dados foi realizada individualmente, mas a intervenção musical foi em grupo. Nestes casos, os familiares participaram do mesmo grupo e foram orientados a evitar o contato visual uns com os outros para que as possíveis emoções manifestadas não influenciassem a percepção dos demais. Para os familiares alocados no Grupo 1 (controle), bem como no Grupo 3 (música instrumental) que tiverem interesse em ouvir as músicas cantadas, o pesquisador se comprometeu em atendê-los, no último encontro, após a coleta de dados.

\subsection{DIRETRIZES PARA RELATÓRIOS DE INTERVENÇÕES MUSICAIS}

Para descrever, com transparência e especificidade a intervenção proposta, foram adotadas as diretrizes recomendadas para relatórios de intervenções musicais na área da saúde, ponderando a complexidade de estímulos musicais e outros fatores como a escolha da música, o modo de entrega, ou a combinação de música com outras estratégias de intervenção, sobretudo a importância atribuída à descrição detalhada, pois permite comparações entre estudos e replicação dos mesmos ${ }^{206}$.

Referencial teórico: racional da música selecionada; especifica como as qualidades musicais podem desencadear os desfechos desejados ${ }^{206}$. No presente estudo, o referencial teórico adotado foi a música sacra, ou seja, músicas constituídas de certa santidade, 
compostas para a celebração litúrgica do culto à Deus ${ }^{207}$, cujos texto, estilo e forma, se alinham com registros afetivos implícitos, filtrados através de constelações intrapsíquicas, e funcionam, talvez, como o mais potente catalisador em facilitar experiências espirituais. $\mathrm{O}$ seu potencial evocativo pode transportar os ouvintes para dimensões inacessíveis da psique ${ }^{195,208 \text {, }}$ 209.

Conteúdo da intervenção: detalhes da intervenção musical e descrição das intervenções construídas com os indivíduos; é subdividido em cinco componentes ${ }^{206}$ :

1. Pessoa que seleciona a música: especifica se a música foi pré-selecionada pelo pesquisador, selecionada pelo participante a partir de um repertório pré-determinado, ou de sua própria coleção, ou baseada na sua avaliação. No presente estudo, as músicas foram préselecionadas pelo pesquisador, a partir de sua apreciação pessoal, porém, considerando a letra das músicas, de forma a evitar associação com crenças religiosas.

2. Música: especifica se foi utilizada uma gravação e, neste caso, é preciso indicar a referência (álbum), partitura ou análise musical; ou, no caso de improvisação ou originalidade, indicar a estrutura global da música, incluindo forma, tempo, ritmo, melodia, harmonia, sonoridade, tonalidade, dinâmica, andamento e instrumentação. No presente estudo foi utilizado a originalidade, entretanto, objetivando intensificar o rigor metodológico, optouse por descrever ambas informações.

As músicas utilizadas compõem o álbum "Vida Agora e Sempre" da gravadora COMEP - Vossa presença faz viver ${ }^{210}$ (Música 1); Prece ao Deus vivo ${ }^{211}$ (Música 2); Quando a dor chegar ${ }^{212}$ (Música 3) (Anexo 4) - que foram interpretadas pelo Coral Imaculada Conceição, sob regência do Frei Luiz Turra, cujo texto de fundamentação bíblica e autoria do próprio regente, versa sobre fé, esperança, morte e ressurreição. Vale salientar que a estrutura das músicas compreende os ritmos ternário, quaternário e quaternário, e foram executadas nas tonalidades de Ré maior, Ré maior e Sol maior, respectivamente.

Concernente à estrutura global das músicas, optou-se por adotar como referencial teórico, o Expanded Lens Model, oriundo da psicologia, utilizado na compreensão dos processos de comunicação emocional em música. De acordo com este referencial, os compositores e intérpretes utilizam códigos musicais para comunicar emoções específicas aos ouvintes, denominados "pistas acústicas", que fornecem descritores de baixo e alto níveis específicos para determinado tipo de emoção ${ }^{213}$. 
O processo de análise musical realizado no presente estudo, por outro profissional, uma pianista ${ }^{\mathrm{iv}}$, identificou as seguintes pistas acústicas:

- andamento moderado com pouca variabilidade;

- modo maior com harmonia simples consoante;

- intensidade média com pouca variabilidade;

- frequências médias ou baixas (mais evidente na intervenção com música cantada), e frequências médias ou altas (mais evidente na intervenção com música instrumental), com pouca variabilidade ou variabilidade moderada em ambos os casos;

- contorno melódico ascendente;

- articulação legato com pouca variabilidade;

- ritmo regular;

- timbre suave (mais evidente na intervenção com música cantada) ou brilhante (mais evidente na intervenção com música instrumental);

- ataques rápidos;

- ausência de vibrato;

- pouco contraste entre a duração das notas;

- acentuação sobre notas harmonicamente estáveis.

Ressalta-se que as pistas acústicas identificadas, nas músicas utilizadas, convergem com a descrição das pistas acústicas inerentes às emoções alegria e serenidade, descritas no estudo que objetivou investigar a percepção de emoções em música brasileira, e que os modos menores estão associados às emoções tristeza, raiva e medo ${ }^{213}$.

3. Método (reprodução musical, ou ao vivo): envolve o equipamento utilizado, quem determina o volume, o limite de decibéis, o tamanho e a performance do grupo. $\mathrm{O}$ método de apresentação musical foi ao vivo e em volume agradável aos ouvidos, porém, não foram mensurados níveis de decibéis.

4. Materiais da intervenção: abrange os materiais musicais e não musicais. No Grupo 2 - música cantada - foram utilizados voz humana masculina (tenor), um violão acústico e as letras das músicas com seus respectivos acordes musicais (materiais musicais). No Grupo 3 - música instrumental - foram utilizados flauta doce (contralto), violão acústico e

\footnotetext{
${ }^{\text {iv }}$ Núbia Carla Ferreira Cabau. Musicista - pianista.
} 
as partituras das músicas (materiais musicais). Em ambos os grupos foram utilizados estante de partitura (material musical); cadeiras e/ou sofás (materiais não musicais)

5. Estratégias de intervenção: descreve as estratégias sob investigação - audição musical, composição, improvisação, análise da letra, ou estimulação rítmica da audição. No presente estudo a estratégia de intervenção foi a audição musical - audição passiva, ou seja, quando o cliente não participa da atividade musical (não canta, não toca um instrumento musical, não acompanha com palmas etc.), apenas ouve a música. Contudo, alguns participantes, voluntariamente, cantarolavam as músicas, acompanhando a execução.

Esquema da intervenção: compreende o número de sessões, duração e frequência. Nos grupos experimentais, foram realizadas quatro sessões de 20 minutos cada, uma vez por semana. No grupo controle, apenas uma sessão, após a coleta de dados, quando o participante manifestava interesse em ouvir as músicas. Ressalta-se que este tempo de audição musical é considerado adequado para que haja um envolvimento com a música e não desperte cansaço no participante. O tempo de audição musical menor que o proposto produz efeitos incompletos e pouco eficazes ${ }^{214}$.

Vale destacar que, para contemplar este critério, o pesquisador precisou repetir as três músicas inteiras, além do refrão da Música 1 e da Música 3, e que a sequência utilizada em todos os encontros foi: Música 1, Música 2 e Música 3. Embora seja possível obter resultados significativos em uma única sessão musical, em virtude da extensão do processo de elaboração do luto, a intenção do pesquisador foi acompanhar os participantes por um mês (quatro semanas), na tentativa de subsidiar um suporte psicossocioespiritual que, provavelmente, não seria possível oferecer em uma única sessão.

Executor da intervenção: especificam-se as qualificações do profissional que executa a intervenção, e quantos profissionais participaram do estudo. No presente estudo, o pesquisador, que é enfermeiro e músico com experiência clínica pregressa, foi quem executou a intervenção. No grupo experimental de música instrumental, também houve a colaboração de uma flautista ${ }^{\mathrm{V}}$, que foi orientada a executar as músicas com a utilização de partituras, minimizando assim, possíveis interações e vieses nos desfechos.

Fidelidade do tratamento: descrevem-se as estratégias utilizadas para garantir que o tratamento e/ou condições de controle sejam conduzidos conforme pretendidos. No presente estudo, o que garantiu as condições de controle foi a aplicação da EBE antes e após a intervenção.

\footnotetext{
${ }^{v}$ Rita de Cássia Frederico Silva. Musicista - flautista.
} 
Cenário: relata-se onde a intervenção foi implementada - local, nível de privacidade e ambiente sonoro. No presente estudo, a intervenção foi realizada no ambiente domiciliar dos participantes, e os níveis de privacidade e ambiente sonoro foram variáveis, de acordo com a dinâmica de cada família e a localização geográfica da residência.

População-alvo: especifica-se se as intervenções foram realizadas para indivíduos ou grupos, incluindo o tamanho do grupo. No presente estudo, esse item variou de acordo com a disponibilidade dos participantes e do pesquisador. A maioria das intervenções foi individual, mas houve intervenções com dois (5 grupos), três (3 grupos), quatro (1 grupo) e sete participantes (1 grupo).

\subsection{TRATAMENTO DOS DADOS}

Os dados foram armazenados em planilha Excel for Windows Explorer ${ }^{\circledR}$ e analisados por meio do software Statistical Package for the Social Sciences - SPSS (Versão 22). Foram realizadas análises estatísticas descritivas, por meio de média e desvio-padrão, frequência absoluta e relativa, e a homogeneidade entre os grupos, quanto às variáveis avaliadas no formulário, foi estudada por meio dos testes de Qui-Quadrado ou Análise de Variância (ANOVA), bem como dos testes de efeitos de interação e intervenção, ao nível de 5\% de significância. Para avaliar a confiabilidade (consistência interna) das respostas dos participantes em relação à EBE foi utilizado o Coeficiente Alfa de Cronbach.

Os domínios da EBE foram estudados entre os grupos, em ambos os momentos aplicados, por meio de ANOVA para medidas repetidas, para avaliar o efeito da intervenção e do tempo. Em seguida foram associados às variáveis estudadas no formulário por meio dos testes Correlação de Pearson (para características com duas categorias), Correlação de Kendall (apropriado para os casos em que algumas das variáveis são ordinais), ou Correlação bisserial (para associar uma variável numérica com uma variável binária). 
Que a palavra de Cristo permaneça em vocês com toda a sua riqueza, de modo que possam instruir-se e aconselhar-se mutuamente com toda a sabedoria. Inspirados pela graça, cantem a Deus, de todo o coração, salmos, hinos e cânticos espirituais.

Paulo, Colossenses, 3:16. 


\section{RESULTADOS}

\subsection{CARACTERIZAÇÃO DA AMOSTRA}

Dos 69 participantes, 19 (27,5\%) eram cônjuges e 50 (72,5\%) eram filhos (Teste QuiQuadrado de Pearson: $\mathrm{p}=0,293)$, sendo $19(27,5 \%)$ do sexo masculino e $50(72,5 \%)$ do sexo feminino. Estes foram alocados, aleatoriamente, em três grupos: Grupo 1 - controle $(\mathrm{N}=23)$, Grupo 2 - música sacra cantada $(\mathrm{N}=23)$ e Grupo 3 - música sacra instrumental $(\mathrm{N}=23)$. A média da idade foi de 47,8 anos (mediana: 48 anos; desvio padrão: 12,9 anos; ANOVA: $\mathrm{p}=0,155)$.

Tabela 1 - Nível de escolaridade dos familiares enlutados. Maringá, PR, Brasil, 2015

\begin{tabular}{lccccccccc}
\hline Nível de escolaridade & \multicolumn{3}{c}{ Grupo 1 } & \multicolumn{2}{c}{ Grupo 2 } & \multicolumn{2}{c}{ Grupo 3 } & \multicolumn{2}{c}{ Total } \\
\cline { 2 - 11 } & $\mathbf{N}$ & $\mathbf{\%}$ & $\mathbf{N}$ & $\mathbf{\%}$ & $\mathbf{N}$ & $\mathbf{\%}$ & $\mathbf{N}$ & $\mathbf{\%}$ \\
\hline Nunca frequentou a escola & 1 & 4,3 & - & - & - & - & 1 & 1,4 \\
Ensino fundamental incompleto & 11 & 47,8 & 11 & 47,8 & 8 & 34,8 & 30 & 43,5 \\
Ensino médio incompleto & 2 & 8,7 & 1 & 4,3 & 3 & 13,0 & 6 & 8,7 \\
Ensino médio completo & 7 & 30,4 & 7 & 30,4 & 8 & 34,8 & 22 & 31,9 \\
Ensino superior incompleto & 2 & 8,7 & 3 & 13,0 & 3 & 13,0 & 8 & 11,6 \\
Ensino superior completo & - & - & 1 & 4,3 & 1 & 4,3 & 2 & 2,9 \\
\hline Total & 23 & 100 & 23 & 100 & 23 & 100 & 69 & 100
\end{tabular}

Teste Qui-Quadrado de Pearson: $\mathrm{p}=0,962$.

Observa-se que o nível de escolaridade da maioria dos participantes $(43,5 \%)$ possui o ensino fundamental incompleto, com maior frequência nos Grupos 1 e $2(47,8 \%)$.

Tabela 2 - Estado civil dos familiares enlutados. Maringá, PR, Brasil, 2015

\begin{tabular}{lcccccccc}
\hline Estado Civil & \multicolumn{2}{c}{ Grupo 1 } & \multicolumn{2}{c}{ Grupo 2 } & \multicolumn{2}{c}{ Grupo 3 } & \multicolumn{2}{c}{ Total } \\
\cline { 2 - 10 } & $\mathbf{N}$ & $\mathbf{\%}$ & $\mathbf{N}$ & $\mathbf{\%}$ & $\mathbf{N}$ & $\mathbf{\%}$ & $\mathbf{N}$ & $\mathbf{\%}$ \\
\hline Solteiro(a) & 5 & 21,7 & 5 & 21,7 & 3 & 13,0 & 13 & 18,8 \\
Casado(a) & 6 & 26,1 & 5 & 21,7 & 11 & 47,8 & 22 & 31,9 \\
União estável & - & - & 1 & 4,3 & 3 & 13,0 & 4 & 5,8 \\
Divorciado(a)/Separado(a) & 1 & 4,3 & 5 & 21,7 & 2 & 8,7 & 8 & 11,6 \\
Viúvo(a) & 11 & 47,8 & 7 & 30,4 & 4 & 17,4 & 22 & 31,9 \\
\hline Total & 23 & 100 & 23 & 100 & 23 & 100 & 69 & 100 \\
\hline
\end{tabular}

Teste Qui-Quadrado de Pearson: $\mathrm{p}=0,090$. 
No que tange ao estado civil, a maioria dos participantes é casado(a) ou viúvo(a) (31,9\% cada), porém a maior representatividade encontra-se nos Grupos 1 e 3, com 47,8\% de viúvos e casados, respectivamente.

Tabela 3 - Religião dos familiares enlutados. Maringá, PR, Brasil, 2015

\begin{tabular}{lcccccccc}
\hline \multirow{2}{*}{ Religião } & \multicolumn{2}{c}{ Grupo 1 } & \multicolumn{2}{c}{ Grupo 2 } & \multicolumn{2}{c}{ Grupo 3 } & \multicolumn{2}{c}{ Total } \\
\cline { 2 - 10 } & $\mathbf{N}$ & $\mathbf{\%}$ & $\mathbf{N}$ & $\mathbf{\%}$ & $\mathbf{N}$ & $\mathbf{\%}$ & $\mathbf{N}$ & $\mathbf{\%}$ \\
\hline Católica & 15 & 65,2 & 15 & 65,2 & 7 & 30,4 & 37 & 53,6 \\
Evangélica & 8 & 34,8 & 8 & 34,8 & 16 & 69,6 & 32 & 46,4 \\
\hline Total & 23 & 100 & 23 & 100 & 23 & 100 & 69 & 100 \\
\hline
\end{tabular}

Teste Qui-Quadrado de Pearson: $\mathrm{p}=0,027$.

Com relação à religião, trata-se de uma amostra de cristãos, cuja maior frequência pode ser observada no Grupo 3 (69,6\% de evangélicos).

Tabela 4 - Importância da religião para os familiares enlutados. Maringá, PR, Brasil, 2015

\begin{tabular}{lcccccccc}
\hline \multirow{2}{*}{ Importância da religião } & \multicolumn{2}{c}{ Grupo 1 } & \multicolumn{2}{c}{ Grupo 2 } & \multicolumn{2}{c}{ Grupo 3 } & \multicolumn{2}{c}{ Total } \\
\cline { 2 - 10 } & $\mathbf{N}$ & $\mathbf{\%}$ & $\mathbf{N}$ & $\mathbf{\%}$ & $\mathbf{N}$ & $\mathbf{\%}$ & $\mathbf{N}$ & $\mathbf{\%}$ \\
\hline Pouco importante & 1 & 4,3 & - & - & - & - & 1 & 1,4 \\
Relativamente importante & 1 & 4,3 & 2 & 8,7 & - & - & 3 & 4,3 \\
Importante & 2 & 8,7 & 2 & 8,7 & 3 & 13,0 & 7 & 10,1 \\
Muito importante & 19 & 82,6 & 19 & 82,6 & 20 & 87,0 & 58 & 84,1 \\
\hline Total & 23 & 100 & 23 & 100 & 23 & 100 & 69 & 100 \\
\hline
\end{tabular}

Teste Qui-Quadrado de Pearson: $\mathrm{p}=0,834$.

Concernente à importância da religião, a maioria dos participantes $(84,1 \%)$ a considera muito importante, sendo a maior representatividade no Grupo 3 (87,0\%).

Tabela 5 - Frequência em missas/cultos dos familiares enlutados. Maringá, PR, Brasil, 2015

\begin{tabular}{lcccccccc}
\hline Frequência em missas/cultos & \multicolumn{2}{c}{ Grupo 1 } & \multicolumn{2}{c}{ Grupo 2 } & \multicolumn{2}{c}{ Grupo 3 } & \multicolumn{2}{c}{ Total } \\
\cline { 2 - 10 } & $\mathbf{N}$ & $\mathbf{\%}$ & $\mathbf{N}$ & $\mathbf{\%}$ & $\mathbf{N}$ & $\mathbf{\%}$ & $\mathbf{N}$ & $\mathbf{\%}$ \\
\hline Raramente frequenta & 4 & 17,4 & 4 & 17,4 & 2 & 8,7 & 10 & 14,5 \\
Frequenta às vezes & 2 & 8,7 & 7 & 30,4 & 4 & 17,4 & 13 & 18,8 \\
Quase sempre frequenta & 1 & 4,3 & 4 & 17,4 & 2 & 8,7 & 7 & 10,1 \\
Sempre frequenta & 16 & 69,6 & 8 & 34,8 & 15 & 65,2 & 39 & 56,5 \\
\hline Total & 23 & 100 & 23 & 100 & 23 & 100 & 69 & 100 \\
\hline
\end{tabular}

Teste Qui-Quadrado de Pearson: $\mathrm{p}=0,197$. 
Observa-se que a maioria dos participantes $(56,5 \%)$ sempre frequenta missas ou cultos, sendo a maior frequência observada no Grupo $1(69,6 \%)$.

Tabela 6 - Apreciação musical dos familiares enlutados. Maringá, PR, Brasil, 2015

\begin{tabular}{|c|c|c|c|c|c|c|c|c|}
\hline \multirow[t]{2}{*}{ Apreciação musical } & \multicolumn{2}{|c|}{ Grupo 1} & \multicolumn{2}{|c|}{ Grupo 2} & \multicolumn{2}{|c|}{ Grupo 3} & \multicolumn{2}{|c|}{ Total } \\
\hline & $\mathbf{N}$ & $\%$ & $\mathbf{N}$ & $\%$ & $\mathbf{N}$ & $\%$ & $\mathbf{N}$ & $\%$ \\
\hline Música Clássica & - & - & - & - & 2 & 8,7 & 2 & 2,9 \\
\hline Música Sertaneja & 9 & 39,1 & 7 & 30,4 & 3 & 13,0 & 19 & 27,5 \\
\hline Música Popular Brasileira & 1 & 4,3 & 2 & 8,7 & 1 & 4,3 & 4 & 5,8 \\
\hline Música Sacra & 12 & 52,2 & 10 & 43,5 & 13 & 56,5 & 35 & 50,7 \\
\hline Samba & - & - & 1 & 4,3 & - & - & 1 & 1,4 \\
\hline Rock & - & - & - & - & 2 & 8,7 & 2 & 2,9 \\
\hline Outros $^{*}$ & 1 & 4,3 & 3 & 13,0 & 2 & 8,7 & 6 & 8,7 \\
\hline Total & 23 & 100 & 23 & 100 & 23 & 100 & 69 & 100 \\
\hline
\end{tabular}

Quanto à apreciação musical, a maioria dos participantes $(50,7 \%)$ aprecia ouvir música sacra, cuja representatividade foi mais expressiva no Grupo 3 (56,5\%).

Tabela 7 - Educação musical dos familiares enlutados. Maringá, PR, Brasil, 2015

\begin{tabular}{lcccccccc}
\hline \multirow{2}{*}{ Educação musical } & \multicolumn{2}{c}{ Grupo 1 } & \multicolumn{2}{c}{ Grupo 2 } & \multicolumn{2}{c}{ Grupo 3 } & \multicolumn{2}{c}{ Total } \\
\cline { 2 - 10 } & $\mathbf{N}$ & $\mathbf{\%}$ & $\mathbf{N}$ & $\mathbf{\%}$ & $\mathbf{N}$ & $\mathbf{\%}$ & $\mathbf{N}$ & $\mathbf{\%}$ \\
\hline Sim & 4 & 17,4 & 2 & 8,7 & 2 & 8,7 & 8 & 11,6 \\
Não & 19 & 82,6 & 21 & 91,3 & 21 & 91,3 & 61 & 88,4 \\
\hline Total & 23 & 100 & 23 & 100 & 23 & 100 & 69 & 100 \\
\hline
\end{tabular}

Teste Qui-Quadrado de Pearson: $\mathrm{p}=0,715$.

Com relação à educação musical, a maioria dos participantes $(88,4 \%)$ não estudou música, principalmente entre os participantes dos Grupos 2 e 3 (91,3\%).

Tabela 8 - Tempo de estudo dos familiares enlutados que tiveram educação musical. Maringá, PR, Brasil, 2015

\begin{tabular}{lcccccccc}
\hline \multirow{2}{*}{ Tempo de estudo } & \multicolumn{2}{c}{ Grupo 1 } & \multicolumn{2}{c}{ Grupo 2 } & \multicolumn{2}{c}{ Grupo 3 } & \multicolumn{2}{c}{ Total } \\
\cline { 2 - 10 } & $\mathbf{N}$ & $\mathbf{\%}$ & $\mathbf{N}$ & $\mathbf{\%}$ & $\mathbf{N}$ & $\mathbf{\%}$ & $\mathbf{N}$ & $\mathbf{\%}$ \\
\hline 3 meses & 2 & 50 & - & - & 1 & 50 & 3 & 37,5 \\
4 meses & 1 & 25 & - & - & - & - & 1 & 12,5 \\
5 meses & 1 & 25 & - & - & - & - & 1 & 12,5 \\
6 meses & - & - & 1 & 50 & - & - & 1 & 12,5 \\
12 meses & - & - & 1 & 50 & 1 & 50 & 2 & 25,0 \\
\hline Total & 4 & 100 & 2 & 100 & 2 & 100 & 8 & 100 \\
\hline
\end{tabular}


Teste Qui-Quadrado de Pearson: $\mathrm{p}=0,771$.

No que tange ao tempo de estudo dos oito familiares que tiveram educação musical, os dois que mais estudaram (12 meses) pertencem aos Grupos 2 e 3.

Tabela 9 - Habilidade de tocar instrumentos musicais dos familiares enlutados. Maringá, PR, Brasil, 2015

\begin{tabular}{lcccccccc}
\hline \multirow{2}{*}{ Habilidade } & \multicolumn{2}{c}{ Grupo 1 } & \multicolumn{2}{c}{ Grupo 2 } & \multicolumn{2}{c}{ Grupo 3 } & \multicolumn{2}{c}{ Total } \\
\cline { 2 - 10 } & $\mathbf{N}$ & $\mathbf{\%}$ & $\mathbf{N}$ & $\mathbf{\%}$ & $\mathbf{N}$ & $\mathbf{\%}$ & $\mathbf{N}$ & $\mathbf{\%}$ \\
\hline Sim & 2 & 8,7 & - & - & - & - & 2 & 2,9 \\
Não & 21 & 91,3 & 23 & 100 & 23 & 100 & 67 & 97,1 \\
\hline Total & 23 & 100 & 23 & 100 & 23 & 100 & 69 & 100 \\
\hline
\end{tabular}

Teste Qui-Quadrado de Pearson: $\mathrm{p}=\overline{0,324}$.

Concernente à habilidade de tocar instrumentos musicais, a maioria dos participantes não a tem $(97,1 \%)$. Os dois únicos participantes que tocam instrumentos musicais pertencem ao Grupo 1. Dentre os participantes que tocam instrumentos musicais, um deles toca violão e cavaquinho e o outro apenas cavaquinho.

Tabela 10 - Hábito de ouvir música dos familiares enlutados. Maringá, PR, Brasil, 2015

\begin{tabular}{lcccccccc}
\hline Hábito de ouvir música & \multicolumn{2}{c}{ Grupo 1 } & \multicolumn{2}{c}{ Grupo 2 } & \multicolumn{2}{c}{ Grupo 3 } & \multicolumn{2}{c}{ Total } \\
\cline { 2 - 10 } & $\mathbf{N}$ & $\mathbf{\%}$ & $\mathbf{N}$ & $\mathbf{\%}$ & $\mathbf{N}$ & $\mathbf{\%}$ & $\mathbf{N}$ & $\mathbf{\%}$ \\
\hline Sim & 18 & 78,3 & 20 & 87,0 & 20 & 87,0 & 58 & 84,1 \\
Não & 5 & 21,7 & 3 & 13,0 & 3 & 13,0 & 11 & 15,9 \\
\hline Total & 23 & 100 & 23 & 100 & 23 & 100 & 69 & 100 \\
\hline
\end{tabular}

Teste Qui-Quadrado de Pearson: $\mathrm{p}=\overline{0,772}$.

Com relação ao hábito de ouvir música, a maioria dos participantes o tem $(84,1 \%)$, cuja maior frequência pode ser observada nos Grupos 2 e 3 (87\%).

Tabela 11 - Músicos nas famílias dos familiares enlutados. Maringá, PR, Brasil, 2015

\begin{tabular}{lcccccccc}
\hline \multirow{2}{*}{ Músicos nas famílias } & \multicolumn{2}{c}{ Grupo 1 } & \multicolumn{2}{c}{ Grupo 2 } & \multicolumn{2}{c}{ Grupo 3 } & \multicolumn{2}{c}{ Total } \\
\cline { 2 - 10 } & $\mathbf{N}$ & $\mathbf{\%}$ & $\mathbf{N}$ & $\mathbf{\%}$ & $\mathbf{N}$ & $\mathbf{\%}$ & $\mathbf{N}$ & $\mathbf{\%}$ \\
\hline Sim & 11 & 47,8 & 11 & 47,8 & 12 & 52,2 & 34 & 49,3 \\
Não & 12 & 52,2 & 12 & 52,2 & 11 & 47,8 & 35 & 50,7 \\
\hline Total & 23 & 100 & 23 & 100 & 23 & 100 & 69 & 100 \\
\hline
\end{tabular}

Teste Qui-Quadrado de Pearson: $\mathrm{p}=\overline{1,000}$. 
Observa-se que a maioria dos participantes $(50,7 \%)$ não tem músicos na família, sendo a maior representatividade nos Grupos 1 e 2 (52,2\%). O Grupo 3 apresenta a maior frequência de músicos nas famílias (52,2\%). Dentre os participantes que referiram ter músicos na família, a maior frequência foi de sobrinhos (14,5\%); primos (13,0\%); tios e filhos $(8,7 \%$ cada); cunhados, irmãos, netos e esposos (2,9\% cada); avô, genro, ex-marido e pai (1,4\% cada).

A média do tempo de luto foi de 5,25 meses (mediana: 5 meses; desvio padrão: 3,5 meses; mínimo: 1 mês; máximo: 12 meses; ANOVA: $\mathrm{p}=0,162$ ). A maioria dos participantes $(95,7 \%)$ referiu ter vivenciado experiências pregressas de morte/luto na família. Apenas três $(4,3 \%)$ disseram não ter vivenciado tais experiências.

Tabela 12 - Grau de parentesco $\left(1^{\mathrm{a}}\right.$ resposta $)$ dos entes queridos relacionados às experiências pregressas de morte/luto dos familiares enlutados. Maringá, PR, Brasil, 2015

\begin{tabular}{lcccccccc}
\hline Grau de parentesco & \multicolumn{2}{c}{ Grupo 1 } & \multicolumn{2}{c}{ Grupo 2 } & \multicolumn{2}{c}{ Grupo 3 } & \multicolumn{2}{c}{ Total } \\
\cline { 2 - 9 } & $\mathbf{N}$ & $\mathbf{\%}$ & $\mathbf{N}$ & $\mathbf{\%}$ & $\mathbf{N}$ & $\mathbf{\%}$ & $\mathbf{N}$ & $\mathbf{\%}$ \\
\hline Pai & 6 & 27,3 & 10 & 47,6 & 8 & 34,8 & 24 & 36,4 \\
Mãe & 3 & 13,6 & - & - & - & - & 3 & 4,5 \\
Cônjuge & 1 & 4,5 & 2 & 9,5 & - & - & 3 & 4,5 \\
Irmãos & 5 & 22,7 & 1 & 4,8 & - & - & 6 & 9,1 \\
Outro familiar & 7 & 31,8 & 8 & 38,1 & 15 & 65,2 & 30 & 45,5 \\
Total & 22 & 100 & 21 & 100 & 23 & 100 & 66 & 100 \\
\hline
\end{tabular}

* Foram consideradas mais de uma alternativa - avós: 40 (58,0\%); tios: 35 (50,7\%); sogros: 10 (14,5\%); cunhados: 9 (13,0\%); sobrinhos: 3 (4,3\%); primos: 2 (2,9\%); genros: $1(1,4 \%)$. Teste Qui-Quadrado de Pearson: $\mathrm{p}=0,006$.

Quanto ao grau de parentesco dos entes queridos relacionados às experiências pregressas de morte/luto dos familiares enlutados, de acordo com a primeira resposta, a maioria $(45,5 \%)$ referiu ter vivenciado tais experiências pela morte de outro familiar, especialmente no Grupo 3 (65,2\%), sendo a morte de avós, a maior frequência entre os grupos (58,0\%). Observa-se que o número de respostas (66) é inferior ao número de participantes (69). Isto se justifica pelo fato de três familiares, um do Grupo 1 e dois do Grupo 2, terem referido que não vivenciaram perdas anteriormente. Como alguns familiares já haviam vivenciado outras perdas, houve respostas secundárias que, embora contemplassem as alternativas apresentadas no formulário (mãe, filhos e irmãos), não foram incluídas no teste estatístico - mãe: 10 (14,5\%); irmãos: 18 (26,1\%); filhos: 5 (7,2\%). 
Tabela 13 - Estilo de apego dominante dos familiares enlutados, em relação aos seus entes queridos. Maringá, PR, Brasil, 2015

\begin{tabular}{lcccccccc}
\hline Estilo de apego dominante & \multicolumn{2}{c}{ Grupo 1 } & \multicolumn{2}{c}{ Grupo 2 } & \multicolumn{2}{c}{ Grupo 3 } & \multicolumn{2}{c}{ Total } \\
\cline { 2 - 10 } & $\mathbf{N}$ & $\mathbf{\%}$ & $\mathbf{N}$ & $\mathbf{\%}$ & $\mathbf{N}$ & $\mathbf{\%}$ & $\mathbf{N}$ & $\mathbf{\%}$ \\
\hline Vínculo fraco & 2 & 8,7 & - & - & 2 & 8,7 & 4 & 5,8 \\
Vínculo intermediário & 1 & 4,3 & 3 & 13,0 & 2 & 8,7 & 6 & 8,7 \\
Vínculo forte & 20 & 87,0 & 20 & 87,0 & 19 & 82,6 & 59 & 85,5 \\
\hline Total & 23 & 100 & 23 & 100 & 23 & 100 & 69 & 100 \\
\hline
\end{tabular}

Teste Qui-Quadrado de Pearson: $\mathrm{p}=0,667$.

Com relação ao estilo de apego, a maioria dos participantes $(85,5 \%)$ referiu ter um vínculo forte com os entes queridos falecidos, com maior representatividade nos Grupos 1 e 2 (87,0\% cada).

Tabela 14 - Duração do processo de morte e morrer dos entes queridos dos familiares enlutados. Maringá, PR, Brasil, 2015

\begin{tabular}{lcccccccc}
\hline \multirow{2}{*}{ Duração do processo } & \multicolumn{2}{c}{ Grupo 1 } & \multicolumn{2}{c}{ Grupo 2 } & \multicolumn{2}{c}{ Grupo 3 } & \multicolumn{2}{c}{ Total } \\
\cline { 2 - 10 } & N & \% & N & \% & N & \% & N & \% \\
\hline Curto $(\leq 6$ meses) & 11 & 47,8 & 6 & 26,1 & 5 & 21,7 & 22 & 31,9 \\
Longo ( $>$ 6 meses $)$ & 12 & 52,2 & 17 & 73,9 & 18 & 78,3 & 47 & 68,1 \\
\hline Total & 23 & 100 & 23 & 100 & 23 & 100 & 69 & 100 \\
\hline
\end{tabular}

Teste Qui-Quadrado de Pearson: $\mathrm{p}=0,146$.

No que tange à duração do processo de morte e morrer de seus entes queridos, a maioria dos participantes $(68,1 \%)$ acompanhou um processo de morte e morrer longo $(>6$ meses), cujo escore foi mais expressivo no Grupo 3 (78,3\%).

Tabela 15 - Distribuição dos familiares enlutados segundo a opção de seguir o tratamento médico proposto para o seu ente querido. Maringá, PR, Brasil, 2015

\begin{tabular}{lcccccccc}
\hline Seguiu o tratamento & \multicolumn{2}{c}{ Grupo 1 } & \multicolumn{2}{c}{ Grupo 2 } & \multicolumn{2}{c}{ Grupo 3 } & \multicolumn{2}{c}{ Total } \\
\cline { 2 - 11 } & $\mathbf{N}$ & $\mathbf{\%}$ & $\mathbf{N}$ & $\mathbf{\%}$ & $\mathbf{N}$ & $\mathbf{\%}$ & $\mathbf{N}$ & $\mathbf{\%}$ \\
\hline Sim & 21 & 91,3 & 23 & 100 & 16 & 69,6 & 60 & 87,0 \\
Não & 2 & 8,7 & - & - & 7 & 30,4 & 9 & 13,0 \\
\hline Total & 23 & 100 & 23 & 100 & 23 & 100 & 69 & 100 \\
\hline
\end{tabular}

Teste Qui-Quadrado de Pearson: $\mathrm{p}=0,008$.

Concernente à opção de seguir o tratamento médico proposto para o seu ente querido, a maioria dos participantes $(87,0 \%)$ o fizeram, sendo $100 \%$ no Grupo 2 . 
Tabela 16 - Circunstância da morte dos entes queridos dos familiares enlutados. Maringá, PR, Brasil, 2015

\begin{tabular}{lccccccccc}
\hline Circunstância da morte & \multicolumn{2}{c}{ Grupo 1 } & \multicolumn{2}{c}{ Grupo 2 } & \multicolumn{2}{c}{ Grupo 3 } & \multicolumn{2}{c}{ Total } \\
\cline { 2 - 11 } & $\mathbf{N}$ & $\mathbf{\%}$ & $\mathbf{N}$ & $\mathbf{\%}$ & $\mathbf{N}$ & $\mathbf{\%}$ & $\mathbf{N}$ & $\mathbf{\%}$ \\
\hline No domicílio & 9 & 39,1 & 2 & 8,7 & 7 & 30,4 & 18 & 26,1 \\
No hospital & 14 & 60,9 & 21 & 91,3 & 16 & 69,6 & 51 & 73,9 \\
\hline Total & 23 & 100 & 23 & 100 & 23 & 100 & 69 & 100 \\
\hline
\end{tabular}

Teste Qui-Quadrado de Pearson: $\mathrm{p}=\overline{0,072}$.

Observa-se que a maioria dos óbitos ocorreu em hospitais $(73,9 \%)$, sendo a maior frequência, observada no Grupo $2(91,3 \%)$.

Tabela 17 - Distribuição dos familiares enlutados em relação à conspiração de silêncio. Maringá, PR, Brasil, 2015

\begin{tabular}{lcccccccc}
\hline Conspiração de silêncio & \multicolumn{2}{c}{ Grupo 1 } & \multicolumn{2}{c}{ Grupo 2 } & \multicolumn{2}{c}{ Grupo 3 } & \multicolumn{2}{c}{ Total } \\
\cline { 2 - 10 } & $\mathbf{N}$ & $\mathbf{\%}$ & $\mathbf{N}$ & $\mathbf{\%}$ & $\mathbf{N}$ & $\mathbf{\%}$ & $\mathbf{N}$ & $\mathbf{\%}$ \\
\hline Sim & 3 & 13,0 & 5 & 21,7 & - & - & 8 & 11,6 \\
Não & 20 & 87,0 & 18 & 78,3 & 23 & 100 & 61 & 88,4 \\
\hline Total & 23 & 100 & 23 & 100 & 23 & 100 & 69 & 100 \\
\hline
\end{tabular}

Teste Qui-Quadrado de Pearson: $\mathrm{p}=\overline{0,084}$.

Quanto à conspiração de silêncio, a maioria dos participantes $(88,4 \%)$ não a fizeram, especialmente os do Grupo 3 (100\%). Com relação à participação dos familiares enlutados nos rituais fúnebres (velório e enterro) de seus entes queridos, todos os participantes (100\%) acompanharam tais rituais.

Tabela 18 - Uso de antidepressivo pelos familiares enlutados, após a morte de seus entes queridos. Maringá, PR, Brasil, 2015

\begin{tabular}{lcccccccc}
\hline \multirow{2}{*}{ Uso de antidepressivo } & \multicolumn{2}{c}{ Grupo 1 } & \multicolumn{2}{c}{ Grupo 2 } & \multicolumn{2}{c}{ Grupo 3 } & \multicolumn{2}{c}{ Total } \\
\cline { 2 - 10 } & $\mathbf{N}$ & $\mathbf{\%}$ & $\mathbf{N}$ & $\mathbf{\%}$ & $\mathbf{N}$ & $\mathbf{\%}$ & $\mathbf{N}$ & $\mathbf{\%}$ \\
\hline Sim & 3 & 13,0 & 1 & 4,3 & - & - & 4 & 5,8 \\
Não & 20 & 87,0 & 22 & 95,7 & 23 & 100 & 65 & 94,2 \\
\hline Total & 23 & 100 & 23 & 100 & 23 & 100 & 69 & 100 \\
\hline
\end{tabular}

Teste Qui-Quadrado de Pearson: $\mathrm{p}=\overline{0,313}$.

Com relação ao uso de antidepressivo após a morte de seu ente querido, a maioria dos participantes $(94,2 \%)$ não consumiram tais medicamentos, sendo a maior representatividade no Grupo $3(100 \%)$. 
Tabela 19 - Uso de outro medicamento pelos familiares enlutados, após a morte de seus entes queridos. Maringá, PR, Brasil, 2015

\begin{tabular}{lccccccccc}
\hline Uso de outro medicamento & \multicolumn{2}{c}{ Grupo 1 } & \multicolumn{2}{c}{ Grupo 2 } & \multicolumn{2}{c}{ Grupo 3 } & \multicolumn{2}{c}{ Total } \\
\cline { 2 - 10 } & $\mathbf{N}$ & $\mathbf{\%}$ & $\mathbf{N}$ & $\mathbf{\%}$ & $\mathbf{N}$ & $\mathbf{\%}$ & $\mathbf{N}$ & $\mathbf{\%}$ \\
\hline Sim & 1 & 4,3 & 3 & 13,0 & 1 & 4,3 & 5 & 7,2 \\
Não & 22 & 95,7 & 20 & 87,0 & 22 & 95,7 & 64 & 92,8 \\
\hline Total & 23 & 100 & 23 & 100 & 23 & 100 & 69 & 100 \\
\hline
\end{tabular}

Anti-hipertensivo: 4 (5,8\%); ansiolítico: 2 (2,9\%).

Teste Qui-Quadrado de Pearson: $\mathrm{p}=0,607$.

No que tange ao uso de outro medicamento após a morte de seu ente querido, a maioria dos participantes $(92,8 \%)$ não o fizeram, sendo a maior frequência, observada nos Grupos 1 e 3 (95,7\% cada). Apenas cinco participantes referiram estar fazendo uso de medicamentos $(5,8 \%$ da amostra). Concernente ao uso de práticas integrativas e complementares após a morte de seu ente querido, apenas um participante, do Grupo 3, estava fazendo Reiki (1,4\% da amostra).

Tabela 20 - Distribuição dos familiares enlutados em relação ao apoio social/comunitário após a morte de seus entes queridos. Maringá, PR, Brasil, 2015

\begin{tabular}{lccccccccc}
\hline \multirow{2}{*}{ Apoio social/comunitário } & \multicolumn{2}{c}{ Grupo 1 } & \multicolumn{2}{c}{ Grupo 2 } & \multicolumn{2}{c}{ Grupo 3 } & \multicolumn{2}{c}{ Total } \\
\cline { 2 - 10 } & $\mathbf{N}$ & $\mathbf{\%}$ & $\mathbf{N}$ & $\mathbf{\%}$ & $\mathbf{N}$ & $\mathbf{\%}$ & $\mathbf{N}$ & $\mathbf{\%}$ \\
\hline Sim & 4 & 17,4 & 6 & 26,1 & 7 & 30,4 & 17 & 24,6 \\
Não & 19 & 82,6 & 17 & 73,9 & 16 & 69,6 & 52 & 75,4 \\
\hline Total & 23 & 100 & 23 & 100 & 23 & 100 & 69 & 100 \\
\hline
\end{tabular}

Teste Qui-Quadrado de Pearson: $\mathrm{p}=0,688$.

Concernente ao apoio social/comunitário após a morte de seus entes queridos, a maioria dos participantes $(75,4 \%)$ referiram não estar recebendo tal apoio, com maior expressividade no Grupo $1(82,6 \%)$.

Tabela 21 - Distribuição dos familiares enlutados em relação ao tratamento psicológico após a morte de seus entes queridos. Maringá, PR, Brasil, 2015

\begin{tabular}{lccccccccc}
\hline Tratamento psicológico & \multicolumn{2}{c}{ Grupo 1 } & \multicolumn{2}{c}{ Grupo 2 } & \multicolumn{2}{c}{ Grupo 3 } & \multicolumn{2}{c}{ Total } \\
\cline { 2 - 10 } & $\mathbf{N}$ & $\mathbf{\%}$ & $\mathbf{N}$ & $\mathbf{\%}$ & $\mathbf{N}$ & $\mathbf{\%}$ & $\mathbf{N}$ & $\mathbf{\%}$ \\
\hline Sim & - & - & 4 & 17,4 & 3 & 13,0 & 7 & 10,1 \\
Não & 23 & 100 & 19 & 82,6 & 20 & 87,0 & 62 & 89,9 \\
\hline Total & 23 & 100 & 23 & 100 & 23 & 100 & 69 & 100 \\
\hline
\end{tabular}

Teste Qui-Quadrado de Pearson: $\mathrm{p}=0,198$. 
Quanto ao tratamento psicológico, a maioria dos familiares $(89,9 \%)$ referiram não estar recebendo, cuja expressividade foi maior no Grupo 2 (100\%).

Tabela 22 - Distribuição dos familiares enlutados em relação ao apoio espiritual/religioso após a morte de seus entes queridos. Maringá, PR, Brasil, 2015

\begin{tabular}{lcccccccc}
\hline \multirow{2}{*}{ Apoio social/comunitário } & \multicolumn{2}{c}{ Grupo 1 } & \multicolumn{2}{c}{ Grupo 2 } & \multicolumn{2}{c}{ Grupo 3 } & \multicolumn{2}{c}{ Total } \\
\cline { 2 - 10 } & $\mathbf{N}$ & $\mathbf{\%}$ & $\mathbf{N}$ & $\mathbf{\%}$ & $\mathbf{N}$ & $\mathbf{\%}$ & $\mathbf{N}$ & $\mathbf{\%}$ \\
\hline Sim & 12 & 52,2 & 17 & 73,9 & 13 & 56,5 & 42 & 60,9 \\
Não & 11 & 47,8 & 6 & 26,1 & 10 & 43,5 & 27 & 39,1 \\
\hline Total & 23 & 100 & 23 & 100 & 23 & 100 & 69 & 100 \\
\hline
\end{tabular}

Teste Qui-Quadrado de Pearson: $\mathrm{p}=\overline{0,387}$.

Observa-se que a maioria dos participantes (60,9\%) estava recebendo apoio espiritual/religioso, tendo sua maior representatividade no Grupo 2 (73,9\%).

\subsection{NÍVEIS DE BEM-ESTAR ESPIRITUAL}

Tabela 23 - Níveis de Bem-Estar Espiritual (EBE), Bem-Estar Religioso (BER) e BemEstar Existencial (BEE), dos familiares enlutados. Maringá, PR, Brasil, 2015

\begin{tabular}{llccc}
\hline Escala/Subescala & Grupo & Média & Desvio padrão & N \\
\hline EBE (antes) & Controle & 106,4 & 9,7 & 23 \\
& Experimental cantada & 103,2 & 12,6 & 23 \\
& Experimental instrumental & 107,4 & 10,5 & 23 \\
& Total & 105,7 & 11,0 & 69 \\
EBE (depois) & Controle & 105,5 & 9,6 & 23 \\
& Experimental cantada & 105,2 & 12,9 & 23 \\
& Experimental instrumental & 108,7 & 9,5 & 23 \\
BER (antes) & Total & 106,5 & 10,8 & 69 \\
& Controle & 57,9 & 4,1 & 23 \\
& Experimental cantada & 56,3 & 5,5 & 23 \\
& Experimental instrumental & 57,4 & 3,9 & 23 \\
BER (depois) & Total & 57,2 & 4,5 & 69 \\
& Controle & 56,9 & 4,4 & 23 \\
& Experimental cantada & 56,4 & 6,1 & 23 \\
& Experimental instrumental & 58,1 & 2,6 & 23 \\
& Total & 57,1 & 4,6 & 69 \\
BEE (antes) & Controle & 48,5 & 7,2 & 23 \\
& Experimental cantada & 46,9 & 8,1 & 23 \\
& Experimental instrumental & 49,9 & 8,5 & 23 \\
& Total & 48,5 & 7,9 & 69 \\
BEE (depois) & Controle & 48,6 & 6,3 & 23 \\
& Experimental cantada & 48,9 & 7,8 & 23 \\
& Experimental instrumental & 50,7 & 8,4 & 23 \\
& Total & 49,4 & 7,5 & 69 \\
\hline
\end{tabular}


As médias dos níveis de bem-estar espiritual revelaram que os participantes tinham altos níveis de EBE (escores de 100 a 120 pontos - bem-estar espiritual positivo) e BER, porém, moderados níveis de BEE (escores de 21 a 49 pontos).

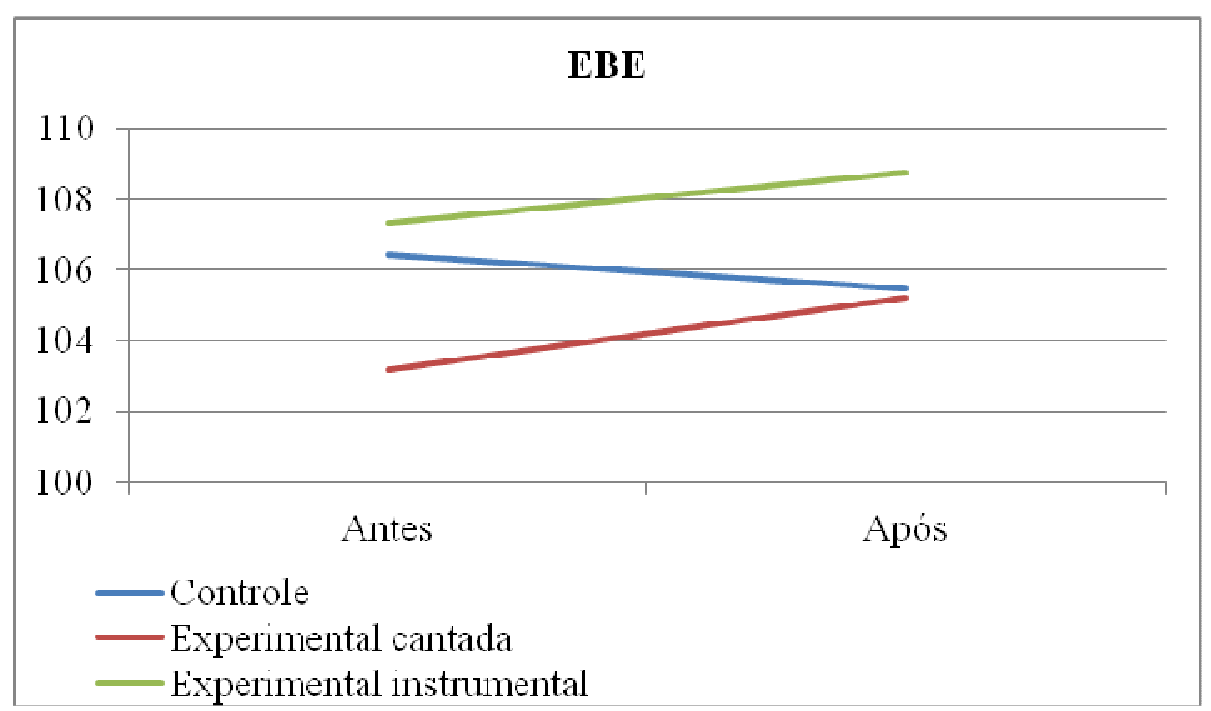

Figura 3. Comparação entre grupos dos efeitos da musicoterapia no Bem-Estar Espiritual (EBE) dos familiares enlutados. Maringá, PR, Brasil, 2015.

Os resultados apresentados na figura 3 revelam uma tendência de que a musicoterapia pode melhorar os níveis de bem-estar espiritual nos Grupos experimentais, em comparação ao Grupo controle.

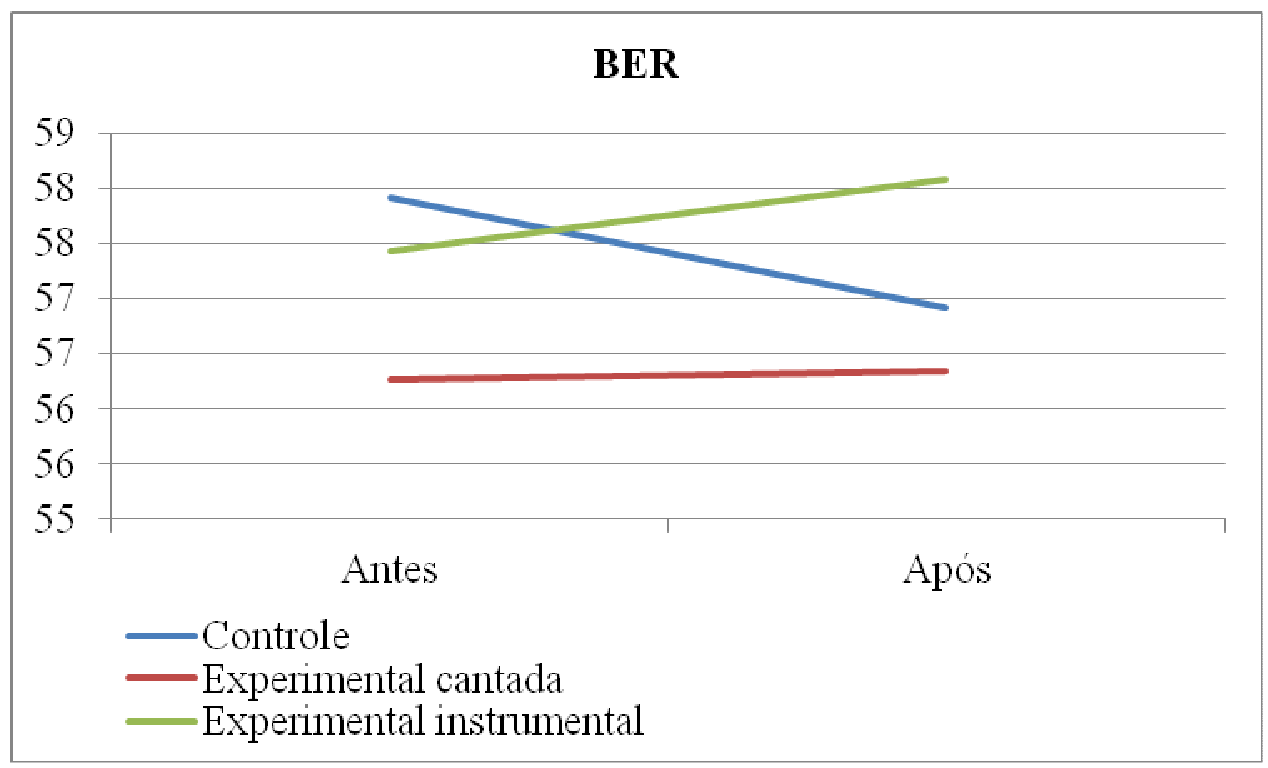

Figura 4. Comparação entre grupos dos efeitos da musicoterapia no Bem-Estar Religioso (BER) dos familiares enlutados. Maringá, PR, Brasil, 2015. 
Em relação ao BER, a tendência se mantém, sendo mais expressiva no Grupo experimental de música instrumental, em detrimento do Grupo controle.

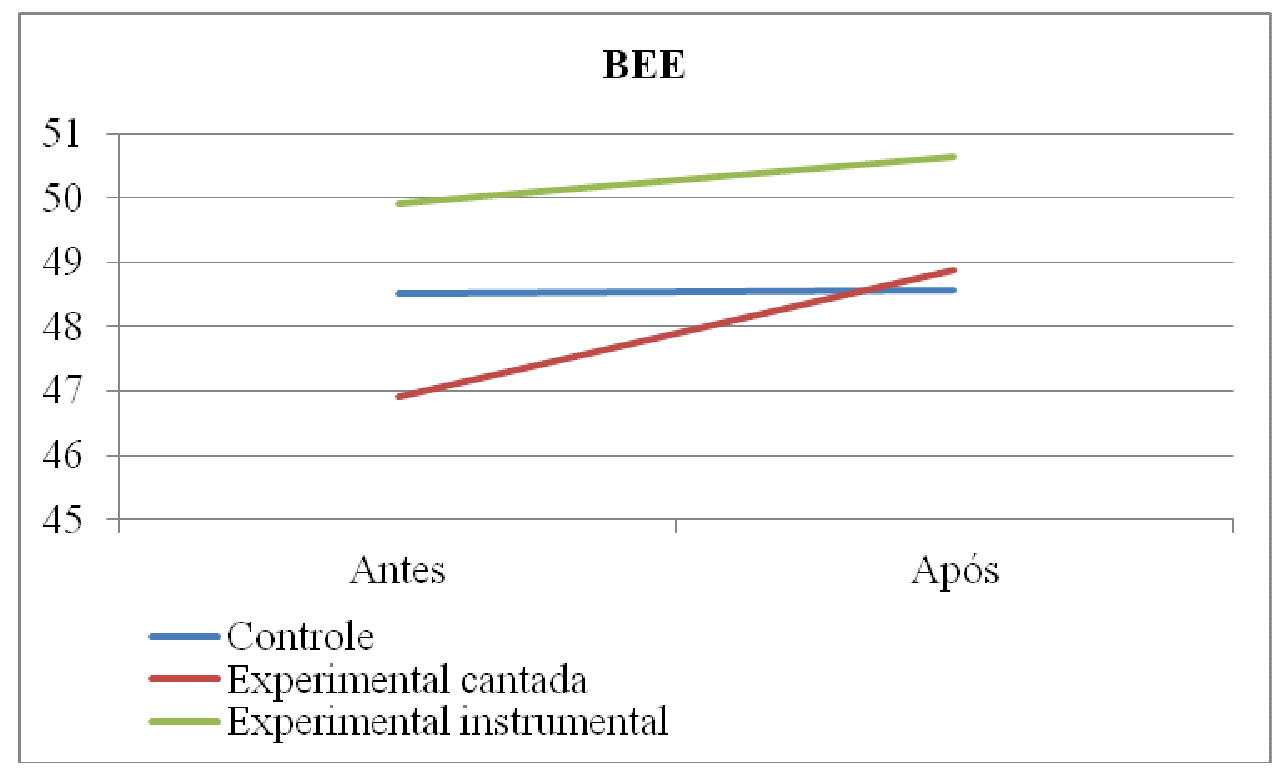

Figura 5. Comparação entre grupos dos efeitos da musicoterapia no Bem-Estar Existencial (BEE) dos familiares enlutados. Maringá, PR, Brasil, 2015.

No que tange ao BEE, a tendência de melhorar volta-se para o Grupo experimental de música cantada e, embora quase imperceptível, os níveis do Grupo controle também diminuem.

Tabela 24 - Efeitos de interação e intervenção, antes e após a intervenção. Maringá, PR, Brasil, 2015

\begin{tabular}{lcc}
\hline Teste & Bem-Estar & p valor \\
\hline Interação & Espiritual & 0,000 \\
& Religioso & 0,000 \\
Intervenção & Existencial & 0,000 \\
& Espiritual & 0,467 \\
& Religioso & 0,857 \\
& Existencial & 0,313 \\
\hline
\end{tabular}

Considerando que o teste de efeito de interação, que verifica se as diferenças entre os escores da EBE, obtidos antes e após a intervenção, foram iguais nos três grupos, e o teste de efeito de intervenção, que verifica se existem tais diferenças, independentemente do grupo, observa-se que não houve diferença estatisticamente significativa em nenhum dos casos.

Tabela 25 - Análise individual dos 20 itens da EBE em relação à validação interna. 
Maringá, PR, Brasil, 2015

\begin{tabular}{|c|c|c|c|c|c|}
\hline \multirow[t]{3}{*}{ Itens } & \multicolumn{4}{|c|}{ Alpha de Cronbach } & \\
\hline & \multicolumn{2}{|c|}{ Antes da intervenção } & \multicolumn{2}{|c|}{ Após a intervenção } & \\
\hline & Coeficiente & p valor & Coeficiente & p valor & $\mathrm{s}$ \\
\hline Q1 & 0,813 & 0,519 & 0,836 & 0,542 & escor \\
\hline Q2 & 0,817 & 0,452 & 0,837 & 0,535 & \\
\hline Q3 & 0,827 & 0,186 & 0,846 & 0,488 & es \\
\hline Q4 & 0,824 & 0,265 & 0,840 & 0,491 & apres \\
\hline Q5 & 0,825 & 0,293 & 0,845 & 0,377 & \\
\hline Q6 & 0,823 & 0,409 & 0,841 & 0,505 & entad \\
\hline Q7 & 0,812 & 0,611 & 0,846 & 0,304 & os na \\
\hline Q8 & 0,810 & 0,560 & 0,839 & 0,482 & \\
\hline Q9 & 0,818 & 0,432 & 0,838 & 0,532 & tabela \\
\hline Q10 & 0,808 & 0,585 & 0,834 & 0,579 & 9 , \\
\hline Q11 & 0,827 & 0,269 & 0,846 & 0,410 & ohtid \\
\hline Q12 & 0,805 & 0,635 & 0,833 & 0,623 & \\
\hline Q13 & 0,815 & 0,463 & 0,843 & 0,401 & os por \\
\hline Q14 & 0,808 & 0,588 & 0,832 & 0,630 & meio \\
\hline Q15 & 0,821 & 0,440 & 0,844 & 0,399 & \\
\hline Q16 & 0,844 & 0,140 & 0,854 & 0,322 & do \\
\hline Q17 & 0,813 & 0,575 & 0,847 & 0,264 & Coefi \\
\hline Q18 & 0,812 & 0,518 & 0,833 & 0,612 & \\
\hline Q19 & 0,823 & 0,385 & 0,845 & 0,344 & ciente \\
\hline Q20 & 0,826 & 0,242 & 0,849 & 0,208 & Alfa \\
\hline Total & 0,826 & & 0,848 & & \\
\hline
\end{tabular}

Cronbach $^{215}$, demonstram alta confiabilidade (consistência interna) nas respostas dos participantes em relação à EBE, haja vista que foram maiores que 0,7.

As informações a seguir referem-se à participação de 61 familiares enlutados (Grupo 1 - controle: $\mathrm{N}=15$; Grupo 2 - música sacra cantada: $\mathrm{N}=23$; Grupo 3 - música sacra instrumental: $\mathrm{N}=23$ ) em pelo menos uma sessão musical. Os demais familiares enlutados (Grupo 1 - controle: $\mathrm{N}=8$ ) optaram por não ouvir as músicas naquele momento.

Tabela 26 - Apreciação estética dos familiares enlutados, em relação à música que mais gostaram de ouvir. Maringá, PR, Brasil, 2015

\begin{tabular}{|c|c|c|c|c|c|c|c|c|c|}
\hline \multirow{3}{*}{ Apreciação estética } & \multirow{2}{*}{\multicolumn{2}{|c|}{ Grupo 1}} & \multirow{2}{*}{\multicolumn{2}{|c|}{ Grupo 2}} & \multirow{2}{*}{\multicolumn{2}{|c|}{ Grupo 3}} & \multirow{2}{*}{\multicolumn{2}{|c|}{ Total }} & \multirow{3}{*}{ p valor ${ }^{* *=1}$} \\
\hline & & & & & & & & & \\
\hline & $\mathbf{N}$ & $(\%)$ & $\mathbf{N}$ & $(\%)$ & $\mathbf{N}$ & $(\%)$ & $\mathbf{N}$ & $(\%)$ & \\
\hline Música 1 & 7 & 30,4 & 7 & 30,4 & 8 & 34,8 & 22 & 31,9 & 1,000 \\
\hline Música 2 & 8 & 34,8 & 6 & 26,1 & 12 & 52,2 & 26 & 37,7 & 0,222 \\
\hline Música 3 & 10 & 43,5 & 18 & 78,3 & 11 & 47,8 & 39 & 56,5 & 0,051 \\
\hline
\end{tabular}

*Alguns participantes escolheram mais de uma música.

*** Teste Qui-Quadrado de Pearson. 
reaplicação da EBE, sobre a música que mais gostaram de ouvir, a maioria dos participantes (56,5\%) referiu a Música 3, cuja representatividade foi maior no Grupo 2 (78,3\%).

Tabela 27 - Sentimentos percebidos pelos familiares enlutados após a intervenção. Maringá, PR, Brasil, 2015

\begin{tabular}{|c|c|c|c|c|c|c|c|c|}
\hline \multirow[t]{2}{*}{ Sentimentos percebidos* } & \multicolumn{2}{|c|}{ Grupo 1} & \multicolumn{2}{|c|}{ Grupo 2} & \multicolumn{2}{|c|}{ Grupo 3} & \multicolumn{2}{|c|}{ Total } \\
\hline & $\mathbf{N}$ & $(\%)$ & $\mathbf{N}$ & $(\%)$ & $\mathbf{N}$ & $(\%)$ & $\mathbf{N}$ & $(\%)$ \\
\hline Bem-estar & 6 & 40,0 & 14 & 60,9 & 10 & 43,5 & 30 & 49,2 \\
\hline Paz/Paz de espírito & 5 & 33,3 & 8 & 34,8 & 5 & 21,7 & 18 & 29,5 \\
\hline Conforto/Reconforto & 3 & 20,0 & 7 & 30,4 & 3 & 13,0 & 13 & 21,3 \\
\hline Relaxamento/Calma/Serenidade & 1 & 6,7 & 4 & 17,4 & 8 & 34,8 & 13 & 21,3 \\
\hline Satisfação & - & - & 4 & 17,4 & 4 & 17,4 & 8 & 13,1 \\
\hline Felicidade/Alegria & 4 & 26,7 & 1 & 4,3 & 3 & 13,0 & 8 & 13,1 \\
\hline Tranquilidade/Quietude & - & - & 2 & 8,7 & 5 & 21,7 & 7 & 11,5 \\
\hline Ânimo & 3 & 20,0 & 1 & 4,3 & 2 & 8,7 & 6 & 9,8 \\
\hline Alívio/Alívio do estresse & - & - & 5 & 21,7 & 1 & 4,3 & 6 & 9,8 \\
\hline Presença de Deus/Comunhão & 4 & 26,7 & 2 & 8,7 & - & - & 6 & 9,8 \\
\hline Saudade & 2 & 13,3 & 1 & 4,3 & 2 & 8,7 & 5 & 8,2 \\
\hline Conformação/Consolo & - & - & 2 & 8,7 & 2 & 8,7 & 4 & 6,6 \\
\hline Suavidade/Leveza & - & - & - & - & 3 & 13,0 & 3 & 4,9 \\
\hline Vontade de chorar & - & - & 3 & 13,0 & - & - & 3 & 4,9 \\
\hline Tristeza & - & - & 1 & 4,3 & 1 & 4,3 & 2 & 3,3 \\
\hline Força/Força de vontade & 1 & 6,7 & 1 & 4,3 & - & - & 2 & 3,3 \\
\hline Fé/Confirmação da fé & 1 & 6,7 & 1 & 4,3 & - & - & 2 & 3,3 \\
\hline Atemporalidade & - & - & 2 & 8,7 & - & - & 2 & 3,3 \\
\hline Presença do familiar & - & - & - & - & 2 & 8,7 & 2 & 3,3 \\
\hline Aconchego/Proteção & 1 & 6,7 & - & - & 1 & 4,3 & 2 & 3,3 \\
\hline Desespero & - & - & - & - & 1 & 4,3 & 1 & 1,6 \\
\hline Segurança & - & - & - & - & 1 & 4,3 & 1 & 1,6 \\
\hline Valorização & 1 & 6,7 & - & - & - & - & 1 & 1,6 \\
\hline Concentração & - & - & - & - & 1 & 4,3 & 1 & 1,6 \\
\hline Distração & - & - & 1 & 4,3 & - & - & 1 & 1,6 \\
\hline Sensação ruim & - & - & - & - & 1 & 4,3 & 1 & 1,6 \\
\hline
\end{tabular}

Alguns participantes mencionaram mais de um sentimento.

Quando inquiridos sobre o que sentiram ao ouvir música sacra (ao vivo), a maioria dos participantes $(49,2 \%)$ referiu ter se sentido bem, o que foi considerado como bem-estar, sendo mais expressivo no Grupo 2 (60,9\%).

Tabela 28 - Razão da escolha musical dos familiares enlutados após a intervenção. 
Maringá, PR, Brasil, 2015

\begin{tabular}{lcccccc}
\hline Razão da escolha musical" & \multicolumn{2}{c}{ Música 1 } & \multicolumn{2}{c}{ Música 2 } & \multicolumn{2}{c}{ Música 3 } \\
\cline { 2 - 7 } & N & Média & N & Média & N & Média \\
\hline Ritmo suave/leve & 1 & 5,3 & - & - & - & - \\
Traz alegria/mais alegre & 2 & 10,5 & 3 & 13,0 & 2 & 5,7 \\
Gostei mais/é bem legal/mais interessante & 4 & 21,1 & 3 & 13,0 & 4 & 11,4 \\
São músicas religiosas/que falam de Deus & 1 & 5,3 & 2 & 8,7 & 1 & 2,9 \\
Traz conforto & 2 & 10,5 & 2 & 8,7 & 3 & 8,6 \\
Toca o coração/a alma & 6 & 31,6 & 5 & 21,7 & 6 & 17,1 \\
Identificação com a letra & 4 & 21,1 & 8 & 34,8 & 10 & 28,6 \\
Mais bonita/melodia linda & 1 & 5,3 & 1 & 4,3 & 3 & 8,6 \\
Preenche o coração & - & - & 1 & 4,3 & - & - \\
Espacialização (viagem)/vai atéy o Pai & - & - & 2 & 8,7 & - & - \\
Provoca emoção/são emocionantes & 1 & 5,3 & - & - & 2 & 5,7 \\
Ritmo agitado/animada & - & - & - & - & 2 & 5,7 \\
Tempo de intervenção & - & - & - & - & 1 & 2,9 \\
Traz calma, paz, tranquilidade & - & - & - & - & - & - \\
Sonoridade suave - flauta & 1 & 5,3 & 2 & 8,7 & 1 & 2,9 \\
Associação com ritmo que aprecia & 1 & 5,3 & 1 & 4,3 & 2 & 5,7 \\
Familiaridade com a melodia & - & - & - & - & 2 & 5,7 \\
Experiências pregressas/lembranças & 1 & 5,3 & 1 & 4,3 & 3 & 8,6 \\
Não sabe & - & - & 1 & 4,3 & - & - \\
\hline Total & 25 & & 32 & & 42 & \\
\hline Alguns participanyyyyyyyyyyyyyyy
\end{tabular}

*Alguns participantes mencionaram mais de uma razão.

Observa-se que a Música 1 foi associada, com maior média, à percepção de que a música toca o coração/a alma; e as Músicas 2 e 3, à identificação com a letra.

Tabela 29 - Correlação entre sentimentos percebidos e razão da escolha musical dos familiares enlutados após a intervenção. Maringá, PR, Brasil, 2015

\begin{tabular}{lcc} 
& & (continua) \\
\hline Sentimentos percebidos & Razão da escolha musical & p valor \\
\hline Alegria & Mais bonita/melodias lindas & 0,000 \\
Saudade & São músicas religiosas/música que fala de Deus & 0,029 \\
Saudade & Associação com ritmo que aprecia & 0,001 \\
Conformação & Mais bonita/melodias lindas & 0,002 \\
Desespero & Não sabe & 0,001 \\
Calma & Não sabe & 0,000 \\
Alívio/alívio do estresse & Traz alegria/mais alegre & 0,018 \\
Alívio/alívio do estresse & Tempo de intervenção & 0,029 \\
Conforto/reconforto & Espacialização (viagem)/vai até o Pai & 0,005 \\
Vontade de chorar & Preenche o coração & 0,000 \\
Vontade de chorar & Espacialização (viagem)/vai até o Pai & 0,002 \\
Vontade de chorar & Ritmo agitado/animada & 0,019 \\
Presença de Deus & Tocaram o coração/a alma & 0,028 \\
Presença de Deus & Espacialização (viagem)/vai até o Pai & 0,029 \\
& & (continuação)
\end{tabular}




\begin{tabular}{lcc}
\hline Sentimentos percebidos & Razão da escolha musical & p valor \\
\hline Presença de Deus & Tempo de intervenção & 0,029 \\
Tranquilidade/quietude & Experiências pregressas/lembranças & 0,000 \\
Ânino & Tocaram o coração/a alma & 0,004 \\
Felicidade & Provoca emoção/são emocionantes & 0,019 \\
Suavidade/leveza & São músicas religiosas/música que fala de Deus & 0,002 \\
Suavidade/leveza & Experiências pregressas/lembranças & 0,019 \\
Serenidade & Ritmo agitado/animada & 0,000 \\
Serenidade & Associação com ritmo que aprecia & 0,000 \\
Consolo & Ritmo agitado/animada & 0,002 \\
Consolo & Tempo de intervenção & 0,000 \\
Tristeza & Experiências pregressas/lembranças & 0,002 \\
Distração & Experiências pregressas/lembranças & 0,000 \\
Fé/confirmação da fé & Sonoridade suave - flauta & 0,000 \\
Segurança & Provoca emoção/são emocionantes & 0,000 \\
Aconchego & Experiências pregressas/lembranças & 0,000 \\
Concentração & Experiências pregressas/lembranças & 0,000 \\
Satisfação & Familiaridade com a melodia & 0,000 \\
Comunhão & Mais bonita/melodias lindas & 0,000 \\
\hline * & &
\end{tabular}

*Correlação de Pearson

O teste de Correlação de Pearson evidenciou correlações estatisticamente significativas entre as variáveis apresentadas na Tabela 29.

\subsection{CORRELAÇÕES DE MEDIDAS NÃO PARAMÉTRICAS}

Tabela 30 - Correlação entre variáveis e a diferença entre os níveis de EBE dos familiares enlutados antes e após a intervenção. Maringá, PR, Brasil, 2015

\begin{tabular}{lccc}
\hline Variáveis & Coeficiente & p valor & Total \\
\hline Idade & $-0,092$ & 0,273 & 69 \\
Escolaridade & 0,054 & 0,569 & 69 \\
Importância da religião & $-0,142$ & 0,152 & 69 \\
Frequência em missas/cultos & $-0,098$ & 0,303 & 69 \\
Tempo de estudo musical & $-0,196$ & 0,518 & 69 \\
Tempo de luto & $-0,062$ & 0,477 & 69 \\
Estilo de apego dominante & $-0,133$ & 0,182 & 69 \\
\hline
\end{tabular}

*Correlação de Kendall

O teste de Correlação de Kendall foi utilizado porque existe um desvio muito grande da normalidade entre os dados apresentados na tabela 30. Os resultados não foram estatisticamente significativos. 
Tabela 31 - Correlação entre variáveis e a diferença entre os níveis de EBE dos familiares enlutados, antes e após a intervenção. Maringá, PR, Brasil, 2015

\begin{tabular}{|c|c|c|c|}
\hline Variáveis & Coeficiente & p valor ${ }^{*}$ & Total \\
\hline Religião & 0,187 & 0,124 & 69 \\
\hline Educação musical & 0,042 & 0,732 & 69 \\
\hline Tocar instrumento musical & 0,053 & 0,667 & 69 \\
\hline Hábito de ouvir música & 0,158 & 0,196 & 69 \\
\hline Parente músico & 0,060 & 0,626 & 69 \\
\hline Pai músico & 0,133 & 0,275 & 69 \\
\hline Esposo músico & $-0,034$ & 0,781 & 69 \\
\hline Sobrinho músico & $-0,192$ & 0,114 & 69 \\
\hline Filho músico & 0,028 & 0,819 & 69 \\
\hline Neto músico & $-0,118$ & 0,334 & 69 \\
\hline Irmão músico & $-0,062$ & 0,613 & 69 \\
\hline Avó músico & 0,081 & 0,509 & 69 \\
\hline Tio músico & 0,111 & 0,363 & 69 \\
\hline Primo músico & 0,030 & 0,804 & 69 \\
\hline Ex-marido músico & $-0,024$ & 0,845 & 69 \\
\hline Genro músico & $-0,011$ & 0,930 & 69 \\
\hline Cunhado músico & 0,078 & 0,525 & 69 \\
\hline Morte - mãe & $-0,179$ & 0,141 & 69 \\
\hline Morte - cônjuge & $-0,119$ & 0,331 & 69 \\
\hline Morte - irmão & $-0,220$ & 0,069 & 69 \\
\hline Morte - filho & 0,035 & 0,773 & 69 \\
\hline Morte - avó & 0,174 & 0,152 & 69 \\
\hline Morte - tio & 0,100 & 0,412 & 69 \\
\hline Morte - primo & 0,078 & 0,525 & 69 \\
\hline Morte - sogro & 0,092 & 0,451 & 69 \\
\hline Morte - sobrinho & $-0,272$ & $0,024^{*}$ & 69 \\
\hline Morte - cunhado & $-0,104$ & 0,394 & 69 \\
\hline Morte - genro & $-0,155$ & 0,204 & 69 \\
\hline Duração do processo de morte e morrer & 0,205 & 0,091 & 69 \\
\hline Conspiração de silêncio & $-0,021$ & 0,861 & 69 \\
\hline Tratamento médico proposto & $-0,104$ & 0,394 & 69 \\
\hline Uso de antidepressivo & $-0,098$ & 0,421 & 69 \\
\hline Uso de outro medicamento & $-0,108$ & 0,378 & 69 \\
\hline Suporte social/comunitário & 0,007 & 0,952 & 69 \\
\hline Tratamento psicológico & 0,149 & 0,221 & 69 \\
\hline Suporte espiritual/religioso & $-0,113$ & 0,355 & 69 \\
\hline Grau parentesco com o falecido & $-0,022$ & 0,857 & 69 \\
\hline Músical & 0,177 & 0,145 & 69 \\
\hline Música2 & 0,102 & 0,406 & 69 \\
\hline Música3 & $-0,080$ & 0,516 & 69 \\
\hline Paz/paz de espírito & 0,168 & 0,168 & 69 \\
\hline Alegria/alegria na alma & $-0,011$ & 0,930 & 69 \\
\hline Saudade & 0,138 & 0,258 & 69 \\
\hline
\end{tabular}




\begin{tabular}{lccc} 
& & & (continuação) \\
\hline Variáveis & Coeficiente & p valor & Total \\
\hline Conformação & 0,096 & 0,430 & 69 \\
Bem-estar & $-0,144$ & 0,236 & 69 \\
Desespero & $-0,011$ & 0,930 & 69 \\
Calma & 0,058 & 0,638 & 69 \\
Alívio/alívio do estresse & 0,034 & 0,784 & 69 \\
Conforto/reconforto & 0,005 & 0,967 & 69 \\
Vontade de chorar & 0,119 & 0,330 & 69 \\
Atemporalidade & $-0,202$ & 0,096 & 69 \\
Proteção & 0,055 & 0,656 & 69 \\
Presença de Deus & 0,084 & 0,494 & 69 \\
Tranquilidade/quietude & 0,001 & 0,993 & 69 \\
Ânimo & 0,167 & 0,171 & 69 \\
Felicidade & 0,203 & 0,094 & 69 \\
Relaxamento & 0,077 & 0,530 & 69 \\
Suavidade/leveza & $-0,119$ & 0,331 & 69 \\
Força/força de vontade & 0,124 & 0,308 & 69 \\
Serenidade & $-0,011$ & 0,930 & 69 \\
Consolo & $-0,109$ & 0,374 & 69 \\
Tristeza & $-0,043$ & 0,723 & 69 \\
Distração & $-0,011$ & 0,930 & 69 \\
Fé/confirmação da fé & $-0,248$ & $0,040 *$ & 69 \\
Segurança & 0,068 & 0,580 & 69 \\
Aconchego & $-0,168$ & 0,168 & 69 \\
Concentração & $-0,168$ & 0,168 & 69 \\
Presença do familiar & 0,134 & 0,273 & 69 \\
Satisfação & 0,105 & 0,392 & 69 \\
Comunhão & $-0,011$ & 0,930 & 69 \\
Valorização & 0,146 & 0,231 & 69 \\
\hline Correção Biss & & \\
\hline
\end{tabular}

*Correlação Bisserial

O teste de Correlação Bisserial demonstrou que houve correlação negativa, estatisticamente significativa, nos casos de experiência pregressa de luto pela morte de um sobrinho $(\mathrm{p}=0,024)$ e sentimento percebido durante a intervenção - fé/confirmação da fé $(\mathrm{p}=$ $0,040)$, porém com baixos coeficientes $(-0,272$ e $-0,248$, respectivamente). 
Louvem a Deus tocando trombetas, louvem a Ele com cítara e harpa! Louvem a Deus com dança e tambor, louvem a Ele com cordas e flauta! Louvem a Deus com címbalos sonoros, louvem a Ele com címbalos vibrantes!

Todo ser que respira louve a Javé! Aleluia!

Salmo 150, 3-6

\section{DISCUSSÃO}




\section{DISCUSSÃO}

Embora os resultados não tenham sido estatisticamente significativos, sugerem que a música sacra pode melhorar os níveis de bem-estar espiritual de familiares enlutados, e que a música sacra cantada pode subsidiar melhores níveis de bem-estar espiritual quando comparado com a música sacra instrumental. Com efeito, a música sacra pode estimular experiências espirituais ${ }^{208}$ e emocionais, influenciando a percepção do familiar enlutado acerca de questões religiosas/existenciais e, consequentemente, os seus níveis de bem-estar espiritual.

Concernente às pistas acústicas, reconhece-se a infinita variedade de estímulos musicais - tonalidade, ritmo e andamento das músicas; a diversidade de instrumentos musicais e as possíveis combinações de timbre (solista, dueto, trio, quarteto, orquestra); a associação com a voz humana (solista, dueto, trio, quarteto, coro); o número de sessões musicais e a duração das mesmas, dentre outros - haja vista que diferentes arranjos musicais despertam diferentes respostas nos ouvintes e nos resultados das intervenções ${ }^{206}$.

Ressalta-se que as qualidades da música sacra derivam de sua capacidade de transformar a percepção temporal do ouvinte produzindo uma sensação de atemporalidade em que a música subsidia um encontro entre a mente e o infinito ${ }^{209}$. Aparentemente existe uma indeterminação de afetos, que impossibilita a associação objetiva entre o evento morte e um trecho melódico que possa ser definido como elemento caracterizador ${ }^{216}$.

No que tange à classificação, embora tenha atraído significativa atenção de pesquisadores, não existe um consenso acerca do tipo de música digno de uma designação "sacra". Por outro lado, musicólogos têm identificado alguns padrões tonais e rítmicos que são tipicamente associados com músicas que carregam esta designação ${ }^{208}$, como seguir uma estrutura melódica específica, na qual certas expectativas rítmicas estão associadas às expectativas tonais. A tensão entre ambas expectativas, a simplicidade melódica do hino e o contraponto sobreposto, asseguram um sentido sacro ${ }^{209}$.

Assim sendo, acredita-se que a ausência de letras nas músicas instrumentais não as descaracteriza como músicas sacras, mesmo se tratando de estruturas musicais menos elaboradas que as tradicionais músicas eruditas, até porque os participantes tinham consciência de que ouviriam músicas sacras instrumentais. Embora não integrassem a coleção musical dos participantes, dois deles, alocados no grupo experimental de música instrumental, 
referiram conhecer pelo menos uma das músicas utilizadas, o que influenciou a escolha musical após a intervenção. Contudo, após ouvirem a versão cantada, concluíram que se tratava apenas de trechos melódicos semelhantes, o que não é difícil de acontecer, considerando que a composição melódica, de qualquer música, utiliza as mesmas sete notas musicais (dó, ré, mi, fá, sol, lá e si) e seus respectivos acidentes (sustenidos e bemóis).

Não obstante, a escassez de estudos de intervenção musical realizados com familiares enlutados ${ }^{23}$, evidenciada na introdução, limita a discussão dos resultados apresentados. Nessa perspectiva, ressalta-se o estudo que objetivou explorar os efeitos da musicoterapia em uma viúva, por meio de 21 sessões de psicoterapia verbal. Os resultados sugerem que a musicoterapia pode facilitar a exploração dos sentimentos e necessidades da pessoa enlutada, no processo de elaboração da perda, além de refinar as habilidades de tomada de decisão. A utilização de técnicas de improvisação, canto e composição, subsidiou a expressão de raiva reprimida desde a infância, contribuindo com a melhora de sua saúde emocional ${ }^{217}$.

A experiência de dois musicoterapeutas, em cenários de cuidados paliativos, ratifica a relevância da composição criativa em terapias no final da vida e no luto, haja vista que, muitas vezes, as composições são emocionantes e desafiadoras, e provocam intensas reflexões, podendo subsidiar estratégias para perceber, compreender e expressar os sentimentos emergentes neste contexto $^{218}$. Com efeito, as canções constituem poderosos recursos para expressar pensamentos e sentimentos, e comunicar mensagens e histórias importantes, possibilitando uma oportunidade para celebrar a vida, chorar as perdas e preservar histórias $^{219}$.

Destaca-se o estudo qualitativo que avaliou a influência da música na aprendizagem e elaboração do luto de seis pessoas que perderam um ente querido, por meio de entrevistas com exercício de elicitação musical - técnica utilizada para revelar reações de uma pessoa, obter percepções do passado e associa-las com pensamentos presentes sobre como a música influenciou e continua influenciando na sua cura e enfrentamento. Os resultados sugerem que as músicas ou estilos musicais previamente selecionados pelos participantes, especialmente os hinos, podem desempenhar importante papel na aprendizagem durante o processo de luto ${ }^{220}$.

Em contrapartida, considerando que os estudos realizados com crianças e adolescentes enlutados podem ter relevância na implementação e no relatório de intervenções musicais em programas de luto, vale destacar o estudo que avaliou os efeitos de grupos de luto, baseados em musicoterapia, no humor e no comportamento de 18 crianças enlutadas nos últimos dois anos, por meio de oito sessões de musicoterapia (grupo experimental) ou sem musicoterapia (grupo controle). Os resultados revelaram diferenças estatisticamente significativas entre o 
Índice de Avaliação do Comportamento para Crianças no ambiente domiciliar, avaliado pelos pais/responsáveis e professores, e o Questionário Grupo de luto, avaliado pelos pais/responsáveis ${ }^{221}$.

Os escores médios da Escala de Auto Avaliação para Depressão e do Índice de Avaliação do Comportamento para Crianças no ambiente escolar não apresentaram diferenças estatisticamente significativas, porém diminuíram após a intervenção. O pesquisador concluiu que a participação em grupos de luto com base em musicoterapia pode reduzir os sintomas de luto entre as crianças avaliadas em ambiente domiciliar ${ }^{221}$.

Evidencia-se, ainda, os resultados do estudo que objetivou desenvolver um instrumento psicométrico para avaliar o processo de elaboração do luto de adolescentes Escala Processo de Luto - sugerem que intervenções musicais específicas, como a composição (songwriting), podem auxiliar na elaboração do luto de adolescentes. Os participantes que receberam musicoterapia eram mais engajados em grupos e capazes de elaborar o luto em relação àqueles que não o fizeram ${ }^{222}$.

Convém lembrar que os referidos estudos ${ }^{221,222}$ integraram a revisão sistemática com meta-análise que objetivou analisar intervenções para crianças e adolescentes enlutados, realizadas antes de junho de 2006. Os resultados evidenciaram como promissores modelos de tratamento, a musicoterapia e a psicoterapia breve focada na perda, e a análise do tamanho de efeito dos 27 estudos analisados mostrou que as duas intervenções mais bem-sucedidas foram implementadas nos estudos supracitados ${ }^{223}$.

Acredita-se na existência de uma relação entre os jovens e a música, que funciona como uma plataforma para conexão e expressão emocional. E embora não tenham sido observadas alterações na autopercepção após a musicoterapia, o estudo de métodos mistos realizado com 16 adolescentes enlutados encontrou importantes resultados no enfrentamento dos mesmos. Recomenda-se a utilização de ferramentas específicas de luto em futuras investigações, com o intuito de capturar o impacto emocional da musicoterapia em adolescentes enlutados ${ }^{224}$.

Evidencia-se ainda que os estudos realizados no contexto da Tanatomusicologia também podem ser relevantes na implementação e no relatório de intervenções musicais em programas de luto. Embora as vigílias de música prescritiva sejam direcionadas às necessidades físicas e espirituais da pessoa que está morrendo ${ }^{225,226}$, ou seja, são realizadas enquanto o paciente está vivo, em consonância com os seus parâmetros fisiológicos, os benefícios desta intervenção podem ser experienciados pelos familiares que o acompanham nesta transição. 
Aparentemente, não existe uma preocupação com os familiares enlutados, isto é, uma continuidade desse cuidado no luto, como se o sofrimento dos familiares deixasse de existir após a morte de seu ente querido. Corroborando esta percepção, o estudo qualitativo que entrevistou 42 familiares enlutados pela morte de pessoas com hipertensão, em decorrência de doenças cerebrovasculares, com o intuito de identificar como os mesmos percebiam a assistência prestada na atenção básica, observou que as famílias não receberam nenhuma visita da equipe da Estratégia Saúde da Família (ESF) no período de luto, provavelmente devido ao despreparo dos profissionais em acompanhá-los nesse momento ${ }^{227}$. Nessa perspectiva, a Tanatomusicologia tem negligenciado o pressuposto filosófico dos cuidados paliativos, de oferecer um sistema de apoio para ajudar a família a lidar com o luto.

A Enfermagem, por sua vez, tem percebido a necessidade dessa continuidade do cuidado após a morte do paciente, e utilizado música ambiente em uma Unidade de Terapia Intensiva (UTI) na Noruega, durante os cuidados pós-morte. Os resultados demonstraram que a música pode ser útil para os enfermeiros que atuam neste contexto, auxiliando na demonstração de respeito pelo corpo que está sendo preparado, bem como para a família, durante a exibição do corpo, contribuindo em seu tempo de luto, tornando-o especial e memorável $^{228}$.

Todavia, ressalta-se o estudo que abordou as percepções de familiares enlutados acerca do impacto de vigílias musicais, realizadas por tanatomusicologistas, sobre os pacientes $^{229}$. Os resultados identificaram correlações estatisticamente significativas entre facilidade para respirar, relaxamento e conforto $(\mathrm{p}<0,001)$, e entre estas medidas e a capacidade do paciente dormir após a vigília $(\mathrm{p}<0,001)$, em detrimento da necessidade de medicação paliativa após a vigília $(\mathrm{p}<0,001)$; menos efeitos sobre a dor; efeitos positivos para o paciente, e para a maioria dos familiares.

Evidencia-se também o estudo qualitativo que explorou o significado da música, em sessões de musicoterapia pré-perda, para sete cuidadores enlutados. Apesar dos autores não terem especificado os recursos musicais utilizados, os resultados sugerem que os benefícios da musicoterapia pré-perda podem ter longo alcance e efeitos de longa duração, afetar positivamente o sofrimento, e transformar o tempo no luto. A música foi referenciada como um "conduíte" através do qual as pessoas podem "viajar" para tempos e lugares de beleza, felicidade, sentido à vida e inspiração; transmite vibrações calmantes, promovendo expressividade e relaxamento ${ }^{230}$.

Destaca-se ainda, o estudo que objetivou examinar se a musicoterapia afetou a percepção da família sobre os sintomas dos pacientes, e a satisfação da família com os 
cuidados que recebiam em um hospice nos Estados Unidos, a partir de uma análise transversal de prontuários médicos eletrônicos, entre 2006 e 2010. Embora os autores também não tenham descrito os recursos musicais utilizados, os resultados sugerem que a musicoterapia está associada com a percepção da família de apoio espiritual significativo e menor dificuldade respiratória. A satisfação da família foi mais evidente nos casos em que o paciente recebeu musicoterapia $(\mathrm{p}<0,01)^{231}$.

Com efeito, ainda se considera incipiente o foco sobre como a musicoterapia pré-perda pode ajudar os familiares após a morte do paciente. Sugere-se que as memórias das sessões e composições de músicas dos pacientes podem confortar os familiares enlutados, e que os musicoterapeutas podem considerar o cuidado pré-perda como um objetivo, quando atua em cuidados paliativos. Nesse contexto, a musicoterapia pré-perda pode ser definida como a intencionalidade de criar oportunidades envolvendo pacientes com condições ameaçadoras da vida e/ou suas famílias ou amigos próximos, que podem permitir melhores experiências de luto, ao produzir memórias e produtos tangíveis, como uma composição, que validam uma vida e caracterizam uma conexão com o falecido ${ }^{232}$.

Analisando a perspectiva de que as crenças religiosas integram, significativamente, a vida de muitas famílias, subsidiando suporte social, emocional e espiritual, e que, portanto não podem ser negligenciadas no processo de doença e de morte ${ }^{19}$, tampouco no processo de luto, o presente estudo também correlacionou os níveis de bem-estar espiritual com variáveis relacionadas à crença religiosa. Embora os resultados não tenham sido estatisticamente significativos, observa-se que a amostra foi constituída exclusivamente por cristãos - 37 católicos $(53,6 \%)$ e 32 evangélicos $(46,4 \%)$ - cuja maioria atribuía muita importância à religião $(84,1 \%)$ e sempre frequentava missas ou cultos $(56,5 \%)$.

Com efeito, todas as religiões possuem cantos e músicas específicos para rituais fúnebres, que desvelam a sutileza interpretativa do mistério da morte ${ }^{216}$. Nesse sentido, evidencia-se o relevante papel da música nas religiões orientais - Hinduísmo, Sikhismo e Budismo - bem como nas religiões ocidentais - Judaísmo, Cristianismo e Islamismo ${ }^{208}$, uma vez que sua associação com a liturgia pode evocar sentimentos religiosos, seja qual for sua proveniência $^{209}$. Efetivamente, a música, o canto e/ou outros estímulos harmoniosos catalisam a potência espiritual da oração ao acessar diretamente o eu espiritual ${ }^{208}$.

O capítulo VI do Concílio Vaticano II de 1963 reverencia a tradição musical da Igreja Católica como "um tesouro de inestimável valor, que excede todas as outras expressões de arte, sobretudo porque o canto sagrado, intimamente unido com o texto, constitui parte necessária ou integrante da Liturgia solene"233:112. Assim sendo, em 1989, Honigsheim 
adverte que a música integra os rituais que acompanham os momentos significativos da vida dos seres humanos, incluindo cerimônias religiosas e funerais ${ }^{234}$. Com efeito, a música, o canto e/ou outros estímulos harmoniosos, catalizam a potência espiritual da oração ao acessar diretamente o eu espiritual ${ }^{208}$.

Nesse sentido, evidencia-se o estudo de revisão sistemática que objetivou sintetizar evidências científicas sobre o efeito e a aplicabilidade de preces intercessoras na recuperação da saúde de pacientes. Embora a descrição metodológica dos estudos analisados - tipo de oração, frequência e duração - seja insuficiente para subsidiar sua replicação e incorporação na prática clínica, os autores concluíram que as preces intercessoras devem ser usadas em cuidados de saúde; que a oração é sempre benéfica, não exerce influência negativa; e que existem recursos na Enfermagem para o seu uso ${ }^{235}$.

De acordo com a Classificação de Intervenções de Enfermagem (NIC), o apoio espiritual deve ser oferecido por enfermeiros assistenciais e o tempo necessário para isso é de 16 a 30 minutos $^{158}$. Seguindo este pensar, a duração da intervenção musical proposta no presente estudo foi adequada. No que concerne ao bem-estar espiritual, a música pode ajudar a criar um ambiente propício à oração e reflexão espiritual, e pode ser um estímulo para contemplar questões existenciais ${ }^{236}$.

Quanto à reflexão existencial, muitos participantes, principalmente do grupo experimental de música instrumental, referiram que durante a intervenção, passava um filme em suas mentes, que era uma oportunidade para parar e pensar na vida e na morte. Ressalta-se o estudo qualitativo realizado na Tanzânia, junto a 17 profissionais envolvidos em cuidados paliativos (oito enfermeiros, sete capelães e dois assistentes sociais). Os resultados revelaram que as canções com mensagens de esperança trazem conforto aos pacientes e que esse estilo musical pode ajudar uma pessoa a morrer em paz $^{236}$.

Contextualizando, o som de tigelas tibetanas, melodias tocadas em harpas e os sons da natureza são exemplos de música utilizados em muitas partes do mundo para esta finalidade. Vale lembrar que, dor, medo, ansiedade, desespero e depressão são comumente encontrados no contexto dos cuidados paliativos, e que a família do paciente também sofre ao rever arrependimentos do passado, enfrentar as exigências do presente e entrever os temores do futuro. Entretanto, a musicoterapia funciona como um catalisador na expressão de sentimentos de tristeza, incerteza, raiva ou alegria ${ }^{236}$.

Com relação às qualidades psicométricas da Escala de Bem-Estar Espiritual (EBE), os resultados do estudo que avaliou a eficácia de diferentes instrumentos para a identificação do diagnóstico de enfermagem Sofrimento Espiritual, revelaram alto índice de consistência 
interna, calculada pelo Coeficiente Alfa de Cronbach, sendo $\alpha=0,93, \alpha=0,88$ e $\alpha=0,93$ para a escala geral e as subescalas de Bem-Estar Religioso (BER) e Bem-Estar Existencial (BEE), respectivamente ${ }^{194}$. Resultados semelhantes foram encontrados no índice geral de confiabilidade da construção da escala $(\alpha=0,86)^{197}$ e do estudo de adaptação e validação brasileira $(\alpha=0,92)^{197}$, bem como nos índices específicos do estudo que avaliou as qualidades psicométricas da EBE em estudantes de pós-graduação da área da saúde $(\alpha=0,92$ para o domínio de BER e $\alpha=0,79$ para o domínio de BEE) ${ }^{237}$.

No presente estudo, os valores de alfa de cronbach antes e após a intervenção foram, respectivamente: $\alpha=0,83$ e $\alpha=0,85$ para a EBE; $\alpha=0,79$ e $\alpha=0,76$ para o BER; $\alpha=0,76$ e $\alpha=0,72$ para o BEE. Quanto aos escores das subescalas de BER e BEE, os participantes apresentaram maior bem-estar religioso (57,2 antes e 57,1 depois) em relação ao bem-estar existencial (48,5 antes e 50,7 depois). Resultados de outros estudos ${ }^{198,199,200}$ sugerem que o bem-estar espiritual encontra-se mais atrelado à percepção de comunhão com Deus ou outro ser superior em detrimento das questões existenciais de realização, sentido e significado da vida, ponderando o maior escore obtido na subescala de bem-estar religioso, corroborando os resultados encontrados no presente estudo.

O fato de o pesquisador reaplicar a EBE logo após a intervenção pode ser considerado um viés. Contudo, este instrumento não especifica quanto tempo após a intervenção o mesmo deve ser reaplicado. Também não é possível assegurar quanto tempo dura o efeito residual da musicoterapia, dificultando o estabelecimento do momento certo para reavaliar.

Por outro lado, outros estudos encontraram médias muito próximas para ambas subescalas, de BER e BEE, sugerindo diferenças entre grupos com e sem problemas clínicos quanto ao grau de valorização de aspectos religiosos ou existenciais ${ }^{111}$, evidenciando correlação positiva significativa entre saúde e bem-estar espiritual ${ }^{201}$. Diante da possibilidade de dissociar os aspectos existenciais dos aspectos religiosos, outro estudo, que optou por utilizar somente a subescala BEE, destaca sua eficácia na investigação da dimensão espiritual $^{194}$.

Todavia, a análise fatorial com rotação oblíqua da EBE indica que a estrutura fatorial da EBE não é clara, e que a presença de um efeito teto em grupos religiosos específicos pode prejudicar os estudos que avaliam associações entre espiritualidade e aspectos relacionados à saúde. Os autores sugerem cautela na utilização do instrumento, apontando a necessidade de estudos de revisão ${ }^{237}$. Assim sendo, acredita-se que o fato de a amostra do presente estudo ter sido constituída exclusivamente por cristãos (católicos e evangélicos) resultou em baixo poder 
discriminante na avaliação dos efeitos da musicoterapia no bem-estar espiritual dos familiares enlutados.

Contudo, ponderando a importância da EBE para a prática clínica, justificada pela facilidade do seu uso, simplicidade de compreensão e pouco tempo para sua operacionalização ${ }^{194}$, sobretudo a inexistência de estudos que identificam os níveis de bemestar espiritual de familiares enlutados, utilizando este instrumento, optou-se por usá-la no presente estudo, com a devida cautela, evidenciando suas fragilidades, limitações e potencialidades em relação à amostra estudada.

No que tange à correlação entre os níveis de bem-estar espiritual e as variáveis sociodemográficas, as relacionadas à crença religiosa, às experiências sonoro-musicais pregressas e aos fatores intervenientes no processo de elaboração do luto, houve correlações negativas, estatisticamente significativas, entre o nível de bem-estar espiritual e as variáveis "experiência pregressa de luto pela morte de um ente querido" - sobrinho $(p=0,024)$ e "sentimento percebido durante a intervenção" - fé, confirmação da fé ( $p=0,040)$, ou seja, nestes casos os familiares tiveram menor aumento nos escores da EBE após a intervenção, porém com baixos coeficientes (-0,272 e -0,248, respectivamente).

Vale lembrar que a maioria dos participantes já havia experienciado o luto pela morte de outro ente querido, seguiu o tratamento médico proposto, não realizou conspiração de silêncio e participou dos rituais fúnebres. Deste modo, infere-se que tais experiências tenham contribuído no atual processo de elaboração do luto, haja vista que, embora a maioria tenha referido ter um vínculo forte com o falecido, os familiares enlutados estavam com a consciência tranquila, em relação à conspiração de silêncio e ao cuidado dispensado ao ente querido, ou seja, experienciavam uma sensação de missão cumprida. Acredita-se ainda que, acompanhar um processo de morte e morrer prolongado, possa subsidiar a oportunidade de vivenciar uma perda gradativa (luto antecipatório), um momento de muito sofrimento, mas também de muita fé e esperança em Deus, preparando-os para o enfrentamento do luto pósmorte com serenidade. No entanto, as variáveis "luto antecipatório", "fases do luto" e "experiência de cuidado nos últimos dias de vida" não foram investigadas no presente estudo.

Observou-se que o bem-estar religioso se mostrou mais sensível à música sacra instrumental e, o bem-estar existencial mais sensível à música sacra cantada, embora sem diferença estatisticamente significativa, que pode estar relacionado à apreciação estética dos participantes. No grupo controle, o bem-estar religioso diminuiu e o bem-estar existencial aumentou discretamente, o que pode estar relacionado a outros dos multifatores intervenientes no processo de elaboração do luto e o desenvolvimento de estratégias de enfrentamento. 
Analisando a influência das músicas sacras instrumentais no bem-estar religioso dos participantes que as ouviram, é possível inferir que a ausência das letras pode ter evitado que se prendessem às mesmas, tendo liberdade para estabelecerem conexões com Deus. Em contrapartida, as letras das músicas podem ter direcionado a reflexão dos participantes do grupo de música sacra cantada, em relação ao sentido e significado da vida, influenciando suas percepções de bem-estar existencial.

A delimitação dos critérios de inclusão não restringiu a participação de familiares enlutados com alto nível de bem-estar espiritual (bem-estar espiritual positivo) antes da intervenção, dificultando a análise dos efeitos da musicoterapia, pois é difícil perceber melhora em quem já está "bem”. Corroborando esta percepção, as intervenções para crianças e adolescentes enlutados, debilitados ou sintomáticos, tendem a mostrar tamanhos de efeito maiores do que as intervenções para crianças e adolescentes enlutados, sem sintomas ${ }^{223}$.

Com efeito, o alto nível de bem-estar espiritual dos familiares enlutados, antes da intervenção, pode ser atribuído ao fato de a amostra ser constituída exclusivamente por cristãos (católicos e evangélicos), onde a maioria atribui muita importância à religião, sempre frequenta missas ou cultos, tinha o hábito de ouvir música, apreciava ouvir música sacra e referiu estar recebendo apoio espiritual/religioso.

Outro critério de inclusão que pode ter dificultado a análise dos efeitos da intervenção é a abrangência do tempo de luto (de um mês a um ano). Considerando a inexistência de um consenso na literatura, acerca da duração do luto e do melhor momento para intervir terapeuticamente, a concepção de que se trata de um processo singular, e a crença de que após um mês de morte o apoio familiar e comunitário diminui, incitando momentos de solidão ${ }^{238}$, convencionou-se a delimitação de tal abrangência. Todavia, os dados poderiam ter sido analisados na perspectiva do tempo de luto (até 3 meses; de 3 a 6 meses; de 6 a 12 meses).

De fato, o suporte social e familiar não acompanha o enlutado durante todo o processo de luto, revelando a necessidade de uma intervenção terapêutica ${ }^{24}$, quando este deixa de existir, pois embora a angústia dos cuidadores diminua após a morte de seus entes queridos, solidão e tristeza podem permanecer ${ }^{239}$. Infere-se ainda que o primeiro ano de luto seja especialmente sentido, pois o enlutado experienciará a ausência de seu ente querido em momentos especiais - familiares e sociais - antes comemorados na sua presença. Por outro lado, o critério de inclusão supracitado também exerceu influência no não consentimento de alguns familiares, alegando que no momento, não mais precisavam de ajuda.

Não obstante, questiona-se se a delimitação de um mês de luto teria alcançado resultados diferentes, pois embora o sofrimento possa ser mais perceptivo e expressivo neste 
intervalo de tempo, evidencia-se que o "primeiro mês após a perda de um ente querido está destinado, muitas vezes, à realização de rituais" que podem inviabilizar a realização de pesquisas $^{238: 54}$. Ressalta-se que alguns familiares se recusaram a participar do presente estudo porque a perda era muito recente e tocar no assunto aumentaria o seu sofrimento. Para alguns participantes foi questionado se a abordagem do pesquisador foi realizada no momento certo, e embora a maioria tenha respondido que sim, o que poderia caracterizar um viés, alguns responderam que se a intervenção tivesse sido realizada antes, teriam chorado o tempo todo ou, talvez, não teriam consentido participar do estudo.

Adverte-se que as ações ou omissões dos profissionais da saúde, como o distanciamento da família enlutada, a ausência de suporte e apoio, podem configurar fatores nocivos ao processo de elaboração do luto ${ }^{240}$. Entretanto, vale destacar um estudo de coorte prospectiva que examinou a frequência com que 161 cuidadores familiares enlutados utilizaram os serviços de apoio ao luto, os preditores de seu uso e as razões para não usa$\operatorname{los}^{241}$.

Os resultados evidenciaram que $112(69,6 \%)$ familiares enlutados não utilizaram tais serviços - cuidados paliativos, aconselhamento profissional, grupos de apoio, suporte religioso - por considerá-los desnecessários ou ineficazes, por se sentirem capazes de se adaptarem bem à perda, sozinhos ou com apoio informal. Dentre os $49(30,4 \%)$ familiares que utilizaram tais serviços, a maioria $(87,8 \%)$ o fez nos primeiros seis meses pós-perda. Os autores sugerem que estudos futuros examinem intervenções específicas para reduzir as barreiras e aumentar a adesão ao uso destes seviços ${ }^{241}$.

Ressalta-se que a presença do pesquisador também constitui parte da intervenção proposta, pois a interação com o participante - a troca de olhares, o sorriso - inerente às intervenções musicais realizadas ao vivo, constitui estímulos adicionais que podem produzir distintos efeitos, inexpressíveis quando a música é reproduzida por um aparelho de som ou fones de ouvidos. Em contrapartida, esta simples presença durante as visitas domiciliárias, a consciência de que alguém se preocupava contigo e dispunha do seu tempo para ouvi-lo, pode ter influenciado a percepção dos participantes e, consequentemente, a melhora nos níveis de bem-estar existencial dos participantes do grupo controle. A presença de outra pessoa - a flautista - e sua inevitável interação com os participantes, também pode ter influenciado os resultados obtidos no grupo experimental de música instrumental. Porém, esta variável não pode ser controlada quando se trata de música ao vivo.

A música sacra instrumental também pode despertar a sensação de presença do ente querido, embora tenha sido verbalizada por apenas dois participantes. Com efeito, esta 
sensação ou impressão de proximidade da figura perdida que, embora desprovida de atributos visuais e auditivos, contribui para a diminuição da dor do luto e o aumento na percepção de segurança $^{63}$, também pode ter influenciado o bem-estar espiritual dos participantes do referido grupo.

Nesse contexto, evidenciam-se os quatro níveis de experiência musical descritos no modelo analítico elaborado por Ruud e Bonde ${ }^{242}$ : fisiológico; sintático; semântico e pragmático. O nível de experiência musical fisiológico refere-se às reações orgânicas ao som, às propriedades físico-acústicas; o sintático está relacionado às regras e aos princípios gerais da estrutura musical, ou seja, ao fenômeno estético, à experiência de coerência e beleza; o semântico está atrelado ao fenômeno existencial e espiritual, que envolve experiências de humor, relevância, significado e sentido; e o pragmático apresenta a música como um processo ou atividade interativa, vinculada ao fenômeno social e cultural, que compreende o lúdico, o ritual e a comunidade.

Enfatiza-se, ainda, que a memória musical constrói a identidade musical do ser humano, articulando sua historicidade e cultura, e está atrelada aos espaços de identificação pessoal, social, tempo/lugar e transpessoal. O espaço de identificação pessoal abrange a consciência emocional e corporal, inerente às crenças básicas; o social envolve o grupo de pertencimento (estilo, valores) e a comunidade; o tempo/lugar reporta-se aos rituais diários, celebrações, fases da vida e nacionalidade; e o transpessoal vincula-se às experiências religiosas, rituais de transição, natureza e sentido de "ser maior"243.

No que tange à razão da escolha musical dos familiares enlutados após a intervenção, o fato de a Música 1 ter sido associada, com maior frequência, à percepção de que a música toca o coração/a alma, pode sugerir que o ritmo ternário, a ela inerente, represente o estímulo musical responsável por desencadear esta percepção, haja visto que as outras músicas possuem ritmos quaternários e que a Música 2 foi executada na mesma tonalidade (Ré maior) que a Música 1. Esta associação pode estar relacionada ao nível de experiência musical semântico e ao espaço de identificação transpessoal.

A maior frequência na escolha das Músicas 2 e 3, em virtude da identificação com as letras, pode estar relacionada ao nível de experiência musical sintático (fenômeno estético) e ao espaço de identificação social (aspectos religiosos), mas, parece indicar, também, a importância da letra, enquanto elemento constituinte da música, no contexto estudado. Concernente às correlações estatisticamente significativas entre os sentimentos percebidos e as razões das escolhas musicais dos familiares enlutados após a intervenção, sugerem um possível efeito terapêutico subjetivo, que pode ser investigado futuramente. 


\subsection{LIMITAÇÕES DO ESTUDO}

A amostra reduzida não permite que os resultados sejam generalizados. O fato de a extensão vocal do pesquisador ser classificada como tenor e a flauta utilizada ser classificada como contralto pode dificultar ou mesmo impedir análises comparativas entre os grupos de intervenção. Embora o objetivo fosse comparar os efeitos da música cantada com a música instrumental, por se tratar de um ensaio clínico randomizado e, considerando que diferentes estímulos musicais desencadeiam diferentes reações nos seres humanos, esta diferença representou mais um fator de heterogeneidade entre os grupos. A impossibilidade de controlar ruídos internos e externos ao ambiente domiciliar e a dificuldade em estabelecer uma amostra homogênea, desejável em ensaios clínicos, também impossibilitam conclusões mais assertivas.

Ao reconhecer a singularidade do processo de elaboração do luto, evidencia-se outra limitação do estudo, a exclusão de familiares enlutados pela morte de outros entes queridos (filhos, avós, tios, irmãos), cuja perda pode, muitas vezes, por diversas razões, ser até mais significativa. Corroborando, a inclusão dos membros de uma mesma família em um único grupo, fato que também pode ser elegível como limitação do estudo, possibilitou, antes mesmo de iniciar a intervenção, a oportunidade dos participantes identificarem, em sua própria família, quem mais precisava de terapia, evidenciando assim a singularidade supracitada. Este autodiagnóstico familiar também foi presenciado entre familiares que integraram grupos distintos.

\subsection{CONTRIbUiÇÕES PARA O AVANÇO DA CIÊNCIA E ARTE DA ENFERMAGEM}

O presente estudo destaca-se ao propor uma inovadora linha de pesquisa, evidenciando a necessidade de cuidado dos familiares enlutados e o quanto a Enfermagem pode contribuir no processo de elaboração do luto, ao utilizar a música como recurso de cuidado à família enlutada. Ressalta-se, ainda, sua contribuição para a consagração da musicoterapia enquanto especialidade de Enfermagem, reconhecida e referenciada pelo Conselho Federal de Enfermagem (COFEN) como Enfermagem em Terapias Holísticas Complementares ${ }^{157}$, ao identificar que, com exceção de um participante, os familiares enlutados não tiveram contato 
com terapias integrativas e complementares, tampouco apoio social/comunitário ou tratamento psicológico, sobretudo ao disponibilizar intervenções musicais aos mesmos.

Nessa perspectiva, sugere-se o desenvolvimento de novas pesquisas, com amostras maiores; que abranjam em seus critérios de inclusão, familiares enlutados há menos de um mês (independentemente do grau de parentesco, ou composição familiar, como pais, irmãos, amigos etc.), que apresentem níveis de bem-estar espiritual moderado ou baixo - bem-estar espiritual negativo - ou diagnósticos de Enfermagem "Pesar complicado" ou "Sofrimento espiritual"; que utilizem outros recursos musicais, como reprodução musical, outros instrumentos ou mais de uma voz humana, e que investiguem a "dose (próxima do) ideal" de musicoterapia no contexto apresentado (quanto tempo; quantas vezes ao dia; por quanto tempo).

Sugere-se que a Teoria da Adaptação de Callista Roy, adotada como referencial teórico do presente estudo, referenciada como uma das Teorias de Enfermagem convergentes com os pressupostos filosóficos dos Cuidados Paliativos ${ }^{182}$, seja utilizada também para respaldar a prática clínica da Enfermagem no cuidado aos familiares enlutados, haja vista que o luto constitui um processo interativo e dinâmico, e as respostas adaptativas do familiar enlutado são passíveis da influência do enfermeiro.

Infere-se que o luto, considerado um estímulo focal, confrontado diretamente pelo familiar enlutado, pode ser manipulado pela simples presença do enfermeiro e pela escuta acolhedora no processo de elaboração da perda. Todavia, o enfermeiro pode também manipular estímulos contextuais, ao utilizar a música como recurso de cuidado ao familiar enlutado, influenciando indiretamente o ambiente, sobretudo os níveis de adaptação do mesmo. Os efeitos terapêuticos multidimensionais desta interação de estímulos, conscientes ou não, provenientes de processos químicos, neuronais e endócrinos, caracterizam estímulos residuais, que podem contribuir no processo de elaboração do luto e, consequentemente, na integralidade relacional defendida por Roy.

Ponderando que o coping (enfrentamento) inato constitui uma característica genética dos seres humanos, ou seja, um mecanismo instintivo de interação e adaptação ao ambiente em transformação ${ }^{182}$, compreende-se o não consentimento de alguns familiares enlutados em participar do presente estudo, justificando que não precisavam de suporte e apoio. Seguindo este pensar, as possíveis melhoras ou manutenção dos níveis de bem-estar espiritual de alguns participantes do grupo controle também podem ser atribuídas ao coping inato, corroborando os resultados do estudo retromencionado ${ }^{241}$. 
Em contrapartida, é no coping adquirido - habilidade desenvolvida no âmbito das experiências vivenciadas - que influencia as respostas adaptativas a estímulos específicos ${ }^{182}$, que a Enfermagem em Cuidados Paliativos deve fundamentar a assistência ao familiar enlutado. Nesse contexto, evidencia-se a relevância das estratégias de comunicação no atendimento à dimensão emocional em cuidados paliativos, cujo conhecimento e aplicabilidade são mais evidentes em profissionais com formação específica nesta área ${ }^{244}$.

Diante da necessidade do familiar enlutado de falar sobre a perda de seu ente querido $^{50}$, o enfermeiro pode utilizar estratégias de comunicação como escuta ativa, reafirmações verbais de solicitude, o toque afetivo, o olhar, o sorriso, a presença frequente e o uso de perguntas abertas ${ }^{244}$ acerca do processo de morte e morrer de seu ente querido e da elaboração do luto (estímulo específico), com o intuito de subsidiar suporte nas estratégias de enfretamento (respostas adaptativas), respeitando a unicidade de cada situação ${ }^{50}$. Ressalta-se que essas estratégias de comunicação transmitem a mensagem de solicitude compassiva daquele que acompanha ${ }^{244}$.

Deste modo, ao articular os atributos da comunicação, da música e dos cuidados paliativos com os fundamentos da Teoria da Adaptação de Callista Roy, considerando que uma "ação paliativa" abrange, dentre outras, medidas não farmacológicas como a comunicação com a família ${ }^{38}$, neste caso mediada e potencializada pela música, que por sua vez pode aproximar as pessoas, viabilizando a interação, por meio de expressões corporais, olhares, sorrisos e toques inerentes à execução musical ${ }^{144}$, evidencia-se a contribuição do presente estudo para o avanço da Ciência e Arte da Enfermagem, pois a musicoterapia com música sacra pode contribuir no processo de adaptação à perda de familiares enlutados. 
Verdade

A porta da verdade estava aberta, mas só deixava passar meia pessoa de cada vez. Assim não era possivel atingir toda a verdade, porque a meia pessoa que entrava só trazia o perfil de meia verdade. E sua segunda metade voltava igualmente com meio perfil.

E os meios perfis não coincidiam. Arrebentaram a porta. Derrubaram a porta.

Chegaram ao lugar luminoso onde a verdade esplendia seus fogos.

Era dividida em metades diferentes uma da outra. Chegou-se a discutir qual a metade mais bela. Nenhuma das duas era totalmente bela. E carecia optar. Cada um optou conforme seu capricho, sua ilusão, sua miopia. Carlos Drummond de Andrade 


\section{CONCLUSÃO}

Com base nos resultados encontrados, não foram aceitas as hipóteses alternativas do estudo $\mathrm{H}_{1}, \mathrm{H}_{2}$ e, parcialmente, $\mathrm{H}_{3}$, ou seja, os familiares enlutados que ouviram música sacra ao vivo não apresentaram melhores níveis de bem-estar espiritual em relação aos familiares enlutados que não o fizeram; os familiares enlutados que ouviram música sacra cantada ao vivo não apresentaram melhores níveis de bem-estar espiritual quando comparado aos familiares enlutados que ouviram música sacra instrumental ao vivo; houve correlações negativas entre o nível de bem-estar espiritual e as variáveis "experiência pregressa de luto pela morte de um ente querido" - sobrinho, e "sentimento percebido durante a intervenção" fé, confirmação da fé.

Embora os resultados não tenham sido estatisticamente significativos, as linhas ascendentes apresentadas nas figuras 3, 4 e 5, sugerem uma tendência de que a musicoterapia pode melhorar os níveis de bem-estar espiritual de familiares enlutados. O fato de ter havido apenas duas perdas de seguimento no Grupo 3 - música instrumental, sobretudo o fato de não ter havido nenhuma perda no Grupo 2 - música cantada, também podem ser considerados como resultados clinicamente significativos, que podem ser explorados em outros estudos. Assim, mesmo com as devidas limitações, sugere-se continuar investindo nessa linha de pesquisa.

As características sociodemográficas, relacionadas à crença religiosa, às experiências sonoro-musicais e aos fatores intervenientes no processo de elaboração do luto são heterogêneas. Observa-se que o tamanho de efeito estimado no cálculo amostral não se manteve, tampouco aumentou. Em geral, os participantes apresentaram alto nível de bemestar espiritual (maior escore no Grupo 3; maior aumento no Grupo 2; alto nível de bem-estar religioso (maior escore no Grupo 3; maior aumento no Grupo 3); e moderado nível de bemestar existencial (maior escore no grupo 3; maior aumento no Grupo 2; alteração de moderado para alto nível no Grupo 3). 
Debaixo do céu há momento para tudo, e tempo certo para cada coisa:

Tempo para nascer e tempo para morrer.

Tempo para plantar e tempo para arrancar a planta;

Tempo para matar e tempo para curar.

Tempo para destruir e tempo para construir.

Tempo para chorar e tempo para rir.

Tempo para gemer e tempo para bailar. Tempo para atirar pedras e tempo para recolher pedras.

Tempo para abraçar e tempo para se separar.

Tempo para procurar e tempo para perder. Tempo para guardar e tempo para jogar fora.

Tempo para rasgar e tempo para costurar.

Tempo para calar e tempo para falar.

Tempo para amar e tempo para odiar.

Tempo para a guerra e tempo para a paz.

Eclesiastes 3:1-8 


\section{CONSIDERAÇÕES FINAIS}

Embora os resultados não sejam estatisticamente significativos, o presente estudo pode direcionar a elaboração de futuras pesquisas e despertar, nos pesquisadores, o interesse por esta linha investigativa. Ponderando que a espiritualidade é multidimensional e multifatorial, o que dificulta sua percepção e mensuração, sobretudo quantitativamente, bem como a sensibilidade da Escala de Bem-Estar Espiritual ao estado de espírito dos familiares enlutados e à perspectiva com que os mesmos interpretavam cada um dos 20 itens da escala, sugere-se, para as futuras pesquisas, a utilização de uma amostra maior, ou de delineamentos metodológicos - misto ou qualitativo, que permitam, respectivamente, conclusões assertivas e generalização dos resultados, e o acesso à subjetividade inerente aos mesmos.

Com base na prática clínica do pesquisador, sobretudo no referencial teórico e nos resultados apresentados no presente estudo, propõe-se uma definição de musicoterapia para a Enfermagem em cuidados paliativos: é a utilização da música enquanto recurso complementar no cuidado de Enfermagem em cuidados paliativos, para prevenir e aliviar o sofrimento físico, emocional, social e espiritual de pessoas em processo de morte e morrer, contribuindo para a sua qualidade de vida e de morte, bem como de seus familiares, promovendo respostas adaptativas às situações emergentes neste contexto, e suporte no processo de elaboração do luto. 


\section{REFERÊNCIAS}

1. Sales CA, Silva VA, Pilger C, Marcon SS. Music in human terminality: the family members' conceptions. Rev. Esc. Enferm. USP. 2011; 45(1):134-40.

2. Silva VA. Encontros musicais como recurso no cuidado de enfermagem em cuidados paliativos oncológicos: uma análise fenomenológica. [dissertação]. Maringá (PR): Universidade Estadual de Maringá; 2011.

3. Silva VA, Sales CA. Musical meetings as a resource in oncologic palliative care for users of a support homes. Rev. Esc. Enferm. USP. 2013; 47(3):626-33. [citado 2015 abr 04]. Disponível em: http://www.scielo.br/pdf/reeusp/v47n3/en_0080-6234-reeusp-47-3-00626.pdf.

4. Silva VA, Marcon SS, Sales CA. Percepções de familiares de pessoas portadoras de câncer sobre encontros musicais durante o tratamento antineoplásico. Rev Bras Enferm. 2014; 67(3):408-14. [citado 2015 abr 04]. Disponível em: http://www.scielo.br/pdf/reben/v67n3/0034-7167-reben-67-03-0408.pdf.

5. Silva VA, Alvim NAT, Marcon SS. Significados e sentidos da identidade musical de pacientes e familiares sob cuidados paliativos oncológicos. Rev. Eletr. Enf. 2014; 16(1):13241. [citado 2015 abr 04]. Disponível em: http://dx.doi.org/10.5216/ree.v16i1.20696.

6. Silva VA, Leão ER, Silva MJP. Assessment of quality of scientific evidence on musical interventions in caring for cancer patients. Assessment of quality of scientific evidence on musical interventions in caring for cancer patients. Interface (Botucatu). 2014; 18(50):479-92.

7. Silva VA, Leão ER, Silva MJP. Avaliação da qualidade metodológica dos relatórios de intervenções musicais na assistência a pacientes com câncer. In: Memorias XIV Coloquio Panamericano de Investigación em Enfermemría; 2014 set. 6-11; Cartagena de Indias. Cartagena de Indias: ACOFAEN; 2014. p. 713.

8. Silva VA, Silva MJP. Sacred music and spiritual well-being of bereaved family: a randomized clinical Trial. In: 14th World Congress of the European Association for Palliative Care. Copenhague. Copenhague: EAPC; 2015. p. 251.

9. Missionários Redentoristas. Na Casa do Pai: encontros para exéquias, velórios, sepultamento e missas. São Paulo: CPP-Congregação do Santo Redentor; 2014.

10. Brasil. Ministério da Saúde. Instituto Nacional do Câncer. Ações de enfermagem para o controle do câncer: uma proposta de integração ensino-serviço. 3. ed. rev. atual. ampl. Rio de Janeiro: INCA; 2008.

11. Brasil. Ministério da Saúde. Instituto Nacional de Câncer José Alencar Gomes da Silva. Coordenação de Prevenção e Vigilância. Estimativa 2014: incidência de câncer no Brasil. Rio de Janeiro: INCA; 2014. [citado 2015 abr 04]. Disponível em: http://www.inca.gov.br/estimativa/2014/estimativa-24042014.pdf. 
12. Brasil. Ministério da Saúde. Portaria no 2.439, de 8 de dezembro de 2005. [citado 2015 set 05]. Disponível em: http://www.saude.pr.gov.br/arquivos/File/retrol/registrocancer/Portaria2439GM_MS.pdf.

13. Brasil. Ministério da Saúde. Portaria n ${ }^{\circ}$ 2.048, de 3 de setembro de 2009. Subseção VIII. Da Política Nacional de Atenção Oncológica; 2009.

14. Santos FS. O desenvolvimento histórico dos cuidados paliativos e a filosofia hospice. In: Santos FS, editor. Cuidados paliativos: diretrizes, humanização e alívio de sintomas. São Paulo: Atheneu; 2011, p. 3-15.

15. Pessini L. A filosofia dos cuidados paliativos: uma resposta diante da obstinação terapêutica. In: Pessini L, Bertachini L. Humanização e cuidados paliativos. São Paulo: Loyola; 2004, 181-208.

16. Seki NH, Galheigo SM. O uso da música nos cuidados paliativos: humanizando o cuidado e facilitando o adeus. Interface (Botucatu) [online]. 2010; 14(33):273-84. [citado 2013 set 05]. Disponível em: http://www.scielo.br/pdf/icse/v14n33/a04v14n33.pdf.

17. Pimenta CAM. Cuidados paliativos: uma nova especialidade do trabalho da enfermagem? Acta Paul Enferm. 2010; 23(3):VII-VIII.

18. Bousso RS. The complexity and simplicity of the experience of grieving. Acta Paul Enferm. 2011; 24(3):VII-VIII.

19. Bousso RS, Poles K, Serafim TS, Miranda MG. Religious beliefs, illness and death: family'sperspectives in illness experience. Rev. Esc. Enferm. USP. 2011; 45(2):391-97.

20. Santos EM, Sales CA. Familiares enlutados: compreensão fenomenológica existencial de suas vivências. Texto \& Contexto Enferm. 2011; 20(Esp):214-22.

21. Leão ER. Reflexões sobre música, saúde e espiritualidade. O Mundo da Saúde. 2007; 31(2):290-6.

22. Leão ER. Imagens mentais decorrentes da audição musical erudita em dor crônica músculo-esquelética: contribuições para a utilização da música pela enfermagem. [tese]. São Paulo (SP): Escola de Enfermagem, Universidade de São Paulo; 2002.

23. Hudgins KD. The effect of music therapy on the grief process and group cohesion of grief support goups. [thesis]. Athens (OH): Ohio University; 2007.

24. Bromberg MHPF. A psicoterapia em situações de perdas e luto. Campinas, SP: Editora Psy; 1998.

25. Chaves JHB, Mendonça VLG, Pessini L, Rego G, Nunes R. Cuidados paliativos na prática médica: contexto bioético. Rev. dor [online]. 2011; 12(3):250-5.

26. Doyle D. Bilhete de plataforma: vivências em cuidados paliativos. 2. ed. São Caetano do Sul, SP: Editora Difusão; Rio de Janeiro: Editora Senac Rio; 2012. 
27. Pessini L, Bertachini L. Novas perspectivas em cuidados paliativos: ética, geriatria, gerontologia, comunicação e espiritualidade. O Mundo da Saúde. 2005; 29(4):491-509.

28. Figueiredo MTA, Figueiredo MGMCA. Apresentação. In: Doyle D. Bilhete de plataforma: vivências em cuidados paliativos. São Caetano do Sul, SP: Editora Difusão; 2012.

29. Floriani CA, Schramm FR. Casas para os que morrem: a história do desenvolvimento dos hospices modernos. Hist. Cienc. Saude-Manguinhos. 2010; 17(supl. 1):165-80.

30. Pessini L, Bertachini L. Nuevas perspectivas em cuidados paliativos. Acta Bioeth. 2006; 12(2):231-42.

31. Pessini L, Bertachini L. O que entender por cuidados paliativos? (Coleção Questões fundamentais da saúde; 8). São Paulo: Paulus; 2006.

32. Pessini L. Cuidados paliativos: alguns aspectos conceituais, biográficos e éticos. Prática Hospitalar. 2005; 41:107-12.

33. Rodrigues IG, Zago MMF. Cuidados paliativos: realidade ou utopia? Cienc. Cuid. Saúde. 2009; 8(supl):136-41.

34. Sales CA. O cuidado no cotidiano da pessoa com neoplasia: compreensão existencial. [tese]. Ribeirão Preto (SP): Escola de Enfermagem de Ribeirão Preto, Universidade de São Paulo; 2003.

35. Kübler-Ross E. Sobre a morte e o morrer: o que os doentes terminais têm para ensinar a médicos, enfermeiras, religiosos e aos seus próprios parentes. 9. ed. São Paulo, SP: Editora WMF Martins Fontes; 2008.

36. World Health Organization. Cancer pain relief and palliative care report. Geneva: WHO; 1990.

37. World Health Organization. Definition of palliative care. Geneva, 2002. [cited 2013 jun 28]. Available from: http://www.who.int/cancer/palliative/definition/en/.

38. Capelas MLV. Indicadores de qualidade para os serviços de cuidados paliativos. Lisboa: Universidade Católica Editora, 2014. 296 p.

39. Avanci BS, Carolindo FM, Góes FGB, Netto NPC. Cuidados paliativos à criança oncológica na situação do viver/morrer: a ótica do cuidar em enfermagem. Esc. Anna Nery. 2009; 13(4):708-16.

40. Waterkemper R, Reibnitz KS. Cuidados paliativos: a avaliação da dor na percepção de enfermeiras. Rev. Gauch. Enferm. 2010; 31(1):84-91.

41. Sales CA, Silva MRB, Borgognoni K, Rorato C, Oliveira WT. Cuidado paliativo: a arte de estar-com-o-outro de uma forma autêntica. Rev. Enferm. UERJ. 2008; 16(2):174-79. 
42. Franco MHP. A família em psico-oncologia. In: Carvalho VA, Franco MHP, Kovács MJ, Liberato RP, Macieira RC, Veit MT et al. Temas em psico-oncologia. São Paulo: Summus; 2008. p. 358-61.

43. Andrade VCC, Mikuni PK, Melo PS, Sales CA. O estar-só e o estar-com um ente querido durante a quimioterapia. Rev Enferm UERJ. 2006; 14(2):226-31.

44. Ferreira NMLA, Souza CLB, Stuchi Z. Cuidados paliativos e família. Rev. Ciênc. Méd. 2008; 17(1):33-42.

45. Maciel MGS, Rodrigues LF, Naylor C, Bettega R, Barbosa SM, Burlá C et al. Critérios de qualidade para os cuidados paliativos no Brasil / documento elaborado pela Academia Nacional de Cuidados Paliativos. Rio de Janeiro: Diagraphic; 2006.

46. Santos FS. Introdução. In: Santos FS, editor. Cuidados paliativos: discutindo a vida, a morte e o morrer. São Paulo: Atheneu; 2009.

47. Santos FS. Perspectivas histórico-culturais da morte. In: Incontri D, Santos FS. A arte de morrer: visões plurais. Bragança Paulista, SP: Editora Comenius; 2007. p. 13-25.

48. Freud S. Luto e melancolia. Tradução: Marilene Carone. São Paulo: Cosac Naify; 2011.

49. Freud S. Totem e tabu, In: Obras Completas de Sigmund Freud, Rio de Janeiro: Imago, 1996.

50. Mazorra L. A construção de significados atribuídos à morte de um ente querido e o processo de luto. [tese]. São Paulo (SP): Pontifícia Universidade Católica de São Paulo; 2009.

51. Klein M. O luto e suas relações com os estados maníaco-depressivos, In: Amor, culpa e reparação e outros trabalhos. Rio de Janeiro: Imago, 1996.

52. Winnicott DW. (1965) Distorção do ego em termos de falso e verdadeiro self. In: O ambiente e os processos de maturação, Porto Alegre, Artes Médicas, 1983.

53. Bowlby J. Perda: tristeza e depressão, In: Apego e Perda, v. 3, São Paulo:

Martins Fontes, 2004.

54. Laplanche J, Pontalis J-B. Vocabulário de Psicanálise, São Paulo: Martins Fontes, 2000.

55. Barone KC. Realidade e luto: um estudo da transicionalidade, São Paulo: Casa do Psicólogo, 2005.

56. Franco MHP. Crises e desastres: a resposta psicológica diante do luto. O Mundo da Saúde. 2012; 36(1):54-8.

57. Educause Learning Iniciative (2007). 7 things you should know about Facebook II. Disponível em: http://net.educause.edu/ir/library/pdf/ELI7025.pdf. Acesso em: 05 set. 2015.

58. Bousso RS, Ramos D, Frizzo HCF, Santos MR, Bousso F. Facebook: um novo locus para a manifestação de uma perda significativa. Psicol. USP. 2014; 25(2): 172-9. 
59. Bowlby J. (1979) Formação e rompimento dos laços afetivos, São Paulo: Martins Fontes, 1990.

60. Marris P. The social construction of uncertainty. In: Parkes C, Marris P, Stevenson-Hinde J. Attachment across the life cycle. Londres: Routledge; 1991, p. 77-90.

61. Casellato G. Luto por abandono: enfrentamento e correlação com a maternidade. [tese]. São Paulo (SP): Pontifícia Universidade Católica de São Paulo; 2004.

62. Bowlby J. Apego. In: Apego e Perda, v. 1, São Paulo: Martins Fontes, 2004.

63. Parkes CM. Luto: estudos sobre a perda na vida adulta. São Paulo: Summus, 1998.

64. Mazorra L. A criança e o luto: vivências fantasmáticas diante da morte do genitor. [dissertação]. São Paulo (SP): Pontifícia Universidade Católica de São Paulo; 2001.

65. Field NP. Wheter to relinquish or mantain a bond with the deceased. In: Stroebe M. (Orgs.) Handbook of bereavement research and practice: advances in theory and intervention. Washington: American Psychological Association, 2008, p. 113-132.

66. Worden JW. Terapia do luto. Porto Alegre: Artes Médicas, 1998.

67. Stroebe M, Schut H, Stroebe W. Health outcomes of bereavement. The Lancet. 2007; 370:1960-73.

68. Stroebe M, Schut H. Meaning making in the dual process model of coping with bereavement. In: Neimeyer R. (Org.). Meaning Reconstruction and the experience of loss. Washington DC: American Psychological Association; 2001, p. 55-73.

69. Franco MHP. Luto como experiência vital. In: Santos FS. Cuidados paliativos: discutindo a vida, a morte e o morrer. São Paulo: Atheneu; 2009, p. 245-55.

70. Neimeyer RA, Baldwin SA, Gillies J. Continuing bonds and reconstructing meaning: Mitigating complications in bereavement. Death Studies. 2006; 30:715-38.

71. Frankl VE. El hombre en busca del sentido último: el análisis existencial y La conciencia espiritual Del ser humano. Buenos Aires: Paidós; 2006.

72. Franqueira AMR. Destruídas ou transformadas: o luto pelo filho adulto sob a ótica das mães. [dissertação]. Rio de Janeiro (RJ): Pontifícia Universidade Católica do Rio de Janeiro; 2013.

73. Thompson SC, Janigian AS. Life schemes: a framework for understanding the search for meaning. Journal of Social and Clinical Psychology. 1988; 7(2-3):260-80.

74. Walsh F. Strengthening family resilience. Nova Iorque: Guilford Press, 1998. 
75. Attig T. Relearning the world: making and finding meanings. In: Neimeyer R. (org.). Meaning Reconstruction and the experience of loss. Washington DC: American Psychological Association, 2001, p. 33-53.

76. Neimeyer R. (Org.) Meaning reconstruction and the experience of loss. Washington DC: American Psychological Association, 2001.

77. Cyrulnik B. Falar de amor à beira do abismo. São Paulo: Martins Fontes, 2006.

78. Franco MHP. Trabalho com pessoas enlutadas. In: Carvalho et al. (Org.). Temas em psico-oncologia. São Paulo: Summus, 2008.

79. Stroebe M, Schut H. The dual process model of bereavement: rationale and description. Death Studies. 1999; 23(3):197-224.

80. Stroebe M, Schut H. Models of coping with bereavement: a review. In: Stroebe M. et al. (Org.). Handbook of bereavement research: consequences, coping and care. Washington: American Psychological Association, 2001b, p. 375-403.

81. Caserta MS, Lund DA. Toward the development of an inventory of daily widowed life (IDWL): Guided by the dual process model of coping with bereavement. Death Studies. 2007; 31(6):505-34.

82. Prigerson HG, Vanderwerker LC. Maciejewisky PK. A case for inclusion of prolonged grief in DSM-V. In: Stroebe MS, Hansson RO, Schut H, Stroebe W. Handbook of bereavement research and practice; advances in theory and intervention. Washington: American Psychological Association; 2008.

83. Prigerson HG, Horowitz MJ, Jacobs SC, Parkes CM, Aslan M, Goodkinet K. et al. Prolonged Grief Disorder: Psychometric Validation of Criteria Proposed for DSM-V and ICD-11. PLOS Med. 2009; 6(8):e 1000121.

84. Lannen PK, Wolfe J., Prigerson HG, Onelov E, Kreicbergs UC. Unresolved grief in a national sample of bereaved parents: impaired mental and physical health 4 to 9 years later. J. Clin. Oncol. 2008; 26(36):5870-6.

85. Rando T. Theories of complicated mourning: a historical review in treatment of complicated mourning. Champaign: Research Press, 1993.

86. Stroebe M, Schut H, Stroebe W. Attachment in coping with bereavement: a theoretical integration. Rev. General Psychology, n.1, v.9, p.48-66, 2005.

87. Parkes CM. Symposium on Complicated Grief. Omega: Journal on death and dying, Nova Iorque, v. 52, n. 1, p. 1-7, 2005-2006.

88. Parkes CM. Love and loss: the roots of grief and its complications. London: Routledge, 2006. 
89. Mikulincer M, Shaver PR. An Attachment perspective on bereavement. In: Stroebe M et al. (Org.). Handbook of bereavement research and practice: advances in theory and intervention. Washington: American Psychological Association, 2008, p. 87-112.

90. Neimeyer R. (Org.). Complicated grief and the quest for meaning: a constructivist contribution. Omega: Journal on death and dying, Nova Iorque, v. 52, n. 1, p. 37-52, 20052006.

91. Stroebe M, Schut H. A conceptual analysis of the field. Omega: Journal on death and dying, Nova Iorque, v. 52, n. 1, p. 53-70, 2005-2006.

92. Walter T. A social constructivist perspective. Omega: Journal on death and dying, Nova Iorque, v. 52, n. 1, p. 71-80, 2005-2006.

93. Stroebe $\mathrm{M}$ et al. Bereavement research: contemporary perspectives. In: Handbook of bereavement research and practice: advances in theory and intervention. Washington: American Psychological Association, p. 3-25, 2008.

94. Farinasso ALC, Labate RC. Luto, religiosidade e espiritualidade: um estudo clínicoqualitativo com viúvas idosas. Rev. Eletr. Enf. [Internet]. 2012; 14(3):588-95. [citado 2013 ago 20]. Disponível em: http://www.fen.ufg.br/revista/v14/n3/v14n3a15.htm.

95. Parkes CM. A Historical overview of the scientific study of bereavement. In: Stroebe M, et al. Organizador. Handbook of bereavement research: consequences, coping and care. Washington DC: American Psychological Association; 2001. p. 25-45.

96. Kovács MJ. Perdas e o processo de luto. In: Incontri D, Santos FS. A arte de morrer: 1visões plurais. Bragança Paulista, SP: Editora Comenius; 2007.

97. Fleck MPA, Borges ZN, Bolognesi G, Rocha NS. Desenvolvimento do WHOQOL, módulo espiritualidade, religiosidade e crenças pessoais. Rev Saúde Pública. 2003; 37(4):44655 .

98. Koenig HG, McCollough ME, Larson DB. Handbook of religion and health. New York: Oxford University Press; 2001.

99. Koenig HG. Religion, spirituality, and health: the research and clinical implications. ISRN Psychiatry. 2012; 2012:278730.

100. Lucchetti G, Almeida L, Granero A. Spirituality for dialysis patients: should the nephrologist address? J Bras Nefrol. 2010;32:128-32.

101. Kimura M, Oliveira AL, Mishima LS, Underwood LG. Cultural adaptation and validation of the Underwood's Daily Spiritual Experience Scale - Brazilian version. Rev Esc Enferm USP. 2012; 46(Spe):99-106.

102. Lucchetti G, Granero A, Bassi R, Latorraca R, Nacif S. Spirituality in clinical practice: what should the general practitioner know? Rev Soc Bras Clín Méd. 2010;8:154-8. 
103. Panzini RG, Maganha C, Rocha NS, Bandeira DR, Fleck MP. Brazilian validation of the Quality of Life Instrument/spirituality, religion and personal beliefs. Rev. Saúde Pública. 2011; 45(1):153-65.

104. Dezorzi LW, Crossetti MGO. A espiritualidade no cuidado de si para profissionais de enfermagem em terapia intensiva. Rev. Latino-Am. Enfermagem. 2008; 16(2):212-7.

105. Penha RM; Silva MJP. Meaning of spirituality for critical care nursing. Texto Contexto Enferm. 2012; 21(2):260-8.

106. Saporetti LA. Espiritualidade em cuidados paliativos. In: Santos FS, editor. Cuidados paliativos: discutindo a vida, a morte e o morrer. São Paulo: Atheneu; 2009.

107. Pesut B, Fowler M, Taylor EJ, Reimer-Kirkham S, Sawatsky R. Conceptualising spirituality and religion for healthcare. Journal of Clinical Nursing. 2008; 17:2803-10.

108. Schleder LP; Parejo LS; Puggina AC; Silva MJP. Spirituality of relatives of patients hospitalized in intensive care unit. Acta paul. enferm. 2013; 26(1):71-8.

109. Chiu L, Emblen JD, Van Hofwegen L, Sawatzky R, Meyerhoff H. An integrative review of the concept of spirituality in the health sciences. Western Journal of Nursing Research. 2004; 26(4):405-28.

110. Ross L. Spiritual care in nursing: an overview of the research to date. J Clin Nurs. 2006; 15(7):852-62.

111. Volcan SMA, Sousa PLR, Mari JJ, Horta BL. Relação entre bem-estar espiritual e transtornos psiquiátricos menores: estudo transversal. Rev Saúde Pública. 2003; 37(4):440-5.

112. Swinton J, Pattison S. Moving beyond clarity: towards a thin, vague, and useful understanding of spirituality in nursing care. Nursing Philosophy. 2010; 11:226-37.

113. Caldeira S, Carvalho EC, Vieira M. Between spiritual wellbeing and spiritual distress: possible related factors in elderly patients with cancer. Rev. Latino-Am. Enfermagem. 2014; 22(1):28-34.

114. Burkhardt M. Commentarry on "Spirituality in nursing and health-related literature: a concept analysis". J Holist Nurs. 2007; 25:263-4.

115. Koenig H, Patterson G, Meador K. Religion index for psychiatric research: a 5-item measure for use in health outcomes studies. Am J Psychiatry. 1997; 154(1):885-6.

116. Lucchetti G, Lucchetti ALG, Peres MFP, Moreira-Almeida A, Leão FC, Koenig HG. Validation of the Duke Religion Index DUREL (Portuguese version). J Relig Health. 2012; 51(2):579-86.

117. Moreira-Almeida A, Lotufo-Neto F, Koenig HG. Religiousness and mental health: a review. Rev Bras Psiquiatria. 2006; 28:242-50. 
118. Dalgalarrondo P. Relações entre duas dimensões fundamentais da vida: saúde mental e religião. Rev Bras Psiquiatria. 2006; 28:177-8.

119. Silva CS, Siqueira J, Stroppa A, Moreira-Almeida A. Coping espiritual e cuidados palitivos. In: Santos FS, editor. Cuidados paliativos: diretrizes, humanização e alívio de sintomas. São Paulo: Atheneu; 2011, p. 175-82.

120. Folkman S, Lazarus RS. Na analysis of coping in a middle-aged community sample. J Health Soc Behav. 1980; 21:219-39.

121. Antoniazzi AS, Dell'Aglio DD, Bandeira DR. O conceito de coping: uma revisão teórica. Estudos de Psicologia (Natal). 1998; 3(2):273-94.

122. Koenig HG, Pargament KI, Nielsen J. Religious coping and health status in medically ill hospitalized older adults. J Nerv Ment Dis. 1998; 186(9):513-21.

123. Chen YY; Koenig HG. Do people turn to religion in times of stress? An examination of change in religiousness among elderly, medically ill patients. The Journal of Nervous and Mental Disease. 2006; 194(2):114-20.

124. Panzini RG, Bandeira DR. Escala de Coping religiosoespiritual: elaboração e validação de constructo. Psicol Estud. 2005; 10(3):507-16.

125. Pargament KI, Koenig HG, Perez LM. The many methods of religious coping: development and initial validation of the RCOPE. J Clin Psychol. 2000; 56(4):519-43.

126. Valcanti, CC. Chaves, ECL, Mesquita AC, Nogueira DA, Carvalho EC. Religious/spiritual coping in people with chronic kidney disease undergoing hemodialysis. Rev. esc. enferm. USP. 2012; 46(4):838-45.

127. Panzini RG, Bandeira DR. Coping (enfrentamento) religioso/espiritual. Rev Psiq Clin. . 2007; 34(1 Supl):126-35.

128. Selli L, Alves JS. O cuidado espiritual ao paciente terminal no exercício da enfermagem e a participação da bioética. Bioethikos. 2007; 1(1):43-52.

129. National Hospice and Palliative Care Organization. Disponível em: http://www.nhpco.org. Acesso em: 27 ago. 2015.

130. Chaves ECL, Carvalho EC, Hass VJ. Validação do diagnóstico de enfermagem Angústia Espiritual: análise por especialistas. Acta Paul Enferm. 2010; 23(2):264-70.

131. Freitas, EO, Vieira MMS, Tsunemi MH, Pessini L, Guerra GM. Tradução e adaptação transcultural do instrumento "Spiritual Assessment Scale" no Brasil. O Mundo da Saúde. 2013; 37(4):401-10.

132. NANDA. Diagnósticos de enfermagem: definições e classificação, 2009-2011. Porto Alegre: Artmed; 2010. 
133. Chaves ECL, Carvalho EC, Goyatá SL, Galvão CM. Spiritual distress: integrative review of literature. Online Braz J Nurs. 2008; 7(2). Disponível em: http://www.objnursing.uff.br/index.php/nursing/article/view/j.1676-4285.2008.1551/358.

Acesso em: 28 ago. 2015.

134. McCloskey JC, Bulechek GM. Classificação das intervenções de enfermagem. Porto Alegre: Artmed; 2010.

135. Carvalho CC, Chaves ECL, Lunes DH, Simão TP, Grasselli CSM, Braga CG. Effectiveness of prayer in reducing anxiety in cancer patients. Rev. esc. enferm. USP. 2014, vol.48, n.4, pp. 684-690.

136. Tosta CE. A prece cura? Brasília Med. 2004; 41(1-4):38-45.

137. Descritores em Ciências da Saúde. Musicoterapia. Disponível em: http://decs.bvs.br/. Acesso em 17 dez 2015.

138. American Music Therapy Association. What is Music Therapy? Disponível em: http://www.musictherapy.org/about/musictherapy/. Acesso em $17 \mathrm{dez} 2015$.

139. Clements-Cortes A. The use of music in facilitating emotional expression in the terminally ill. American Journal of Hospice \& Palliative Medicine. 2004; 21(4):255-60.

140. World Federation of Music Therapy. What is music therapy?. Disponível em: http://www.wfmt.info/wfmt-new-home/about-wfmt/. Acesso em: 06 out. 2011.

141. Chagas M, Pedro R. Musicoterapia: desafios entre a modernidade e a contemporaneidade. Rio de Janeiro, RJ: Bapera; 2008.

142. Bergold LB, Sobral V. Music for care humanization. Online Braz J Nurs. 2003; 2(3). [cited jun 2813. Available from: http://www.uff.br/nepae/siteantigo/objn203bergoldsobral.htm.

143. Dobbro ERL. A música como terapia complementar no cuidado mulheres com fibromialgia. [dissertação]. São Paulo (SP): Escola de Enfermagem, Universidade de São Paulo; 1998.

144. Leão ER, Puggina AC, Gatti MFZ, Almeida AP, Silva MJP. Música e Enfermagem: um recurso integrativo. In: Salles LF, Silva MJP. Enfermagem e as práticas complementares em saúde. São Caetano do Sul, SP: Yendis Editora; 2011, p. 155-74.

145. Munro S, Mount B. Music therapy in paliative care. CMA Journal. 1978; 119(4):102934.

146. Vachiramon V, Sobanko JF, Rattanaumpawan P, Miller CJ. Music Reduces Patient Anxiety During Mohs Surgery: an open-label randomized controlled trial. Dermatol Surg. 2013; 39:298-305.

147. Zanetti CE. O acompanhamento terapêutico (AT) no hospital geral: música e psicologia aplicada à saúde. Rev. SBPH. 2008; 11(1):49-59. 
148. Wazlawick P, Camargo D, Maheirie K. Significados e sentidos da música: uma breve “composição" a partir da psicologia histórico-cultural. Psicol. Estud. 2007; 12(1):105-13.

149. Souza AN. Arte musical e saúde. In: Leão ER. (org). Cuidar de pessoas e música: uma visão multiprofissional. São Paulo: Yendis; 2009, p. 31-49.

150. Ribas JC. Música e Medicina. São Paulo: Edigraf; 1957.

151. Bergold LB, Alvim NAT. Visita musical como uma tecnologia de cuidado. Texto \& Contexto Enferm. 2009; 18(3):532-41.

152. Falco SM, Lobo ML. Martha E. Rogers. In: George JB. Teorias de enfermagem: os fundamentos à prática profissional. Porto Alegre: Artes Médicas Sul; 2000, p. 185-99.

153. Rogers ME. Nursing science and the space age. Nurs Scie Q. 1992; 5(1):27-34.

154. Brasil. Ministério da Saúde. Secretaria de Atenção à Saúde. Departamento de Atenção Básica. Política nacional de práticas integrativas e complementares no SUS - PNPIC-SUS. Brasília, DF, 2006.

155. Conselho Federal de Enfermagem. Resolução COFEN No 197/1997. [citado 2015 jul 25]. Disponível em: http://www.cofen.gov.br/resoluo-cofen-1971997_4253.html.

156. Conselho Federal de Enfermagem. Resolução COFEN No 290/2004. [citado 2015 jul 25]. Disponível em: http://www.cofen.gov.br/resoluo-cofen-2902004-revogada-pela-resoluocofen-n-3892011_4326.html.

157. Conselho Federal de Enfermagem. Resolução COFEN No 389/2011. [citado 2013 jun 28]. Disponível em: http://novo.portalcofen.gov.br/categoria/legislacao/resolucoes.

158. Johnson M, Bulecheck G, Butcher H, Dochterman JM, Maas M, Moorhead S, et al. Ligações entre NANDA, NOC e NIC: diagnósticos, resultados e intervenções de enfermagem. Tradução Regina Machado Garcez. 2. ed. Porto Alegre: Artmed; 2009.

159. Bradt J, Dileo C, Grocke D, Magill L. Music interventions for improving psychological and physical outcomes in cancer patients. Cochrane Database of Systematic Reviews, 2008. In: The Cochrane Library, Issue 4, Art. No CD006911.

160. Zhang JM, Wang P, Yao J, Zhao L, Davis MP, Walsh D, et al. Music interventions for psychological and physical outcomes in cancer: a systematic review and meta-analysis. Support Care Cancer. 2012; 20:3043-53.

161. Chan MF. A randomised controlled study of the effects of music on sleep quality in older people. Journal of Clinical Nursing. 2011; 20:979-87.

162. Cook EL, Silverman MJ. Effects of music therapy on spirituality with patients on a medical oncology/hematology unit: a mixed-methods approach. The Arts in Psychotherapy. 2013; 40:239-44. 
163. Li X-M, Yan H, Zhou K-N, Dang S-N, Wang D-L, Zhang Y-P. Effects of music therapy on pain among female breast cancer patients after radical mastectomy: results from a randomized controlled trial. Breast Cancer Res Treat. 2011; 128:411-19.

164. Leow MQ. Music therapy in the palliative setting: a systematic review. Singapore Nursing Journal. 2011; 38(4):14-21.

165. Caraceni A, Cherny N, Fainsinger R. Pain measurement tools and methods in clinical research in palliative care: recommendations of an expert working group of the European Association of Palliative Care. J Pain Symptom Manage. 2002; 23:239-55.

166. Merkel SI, Voepel-Lewis T, Shayevitz JR, Malviya S. The FLACC: a behavioral scale for scoring postoperative pain in young children. Pediatr Nurs. 1997; 23:2937.

167. Gloth FM III, Scheve AA, Stober CV, Chow S, Prosser J. The Functional Pain Scale: reliability, validity, and responsiveness in an elderly population. J Am Med Dir Assoc 2001; $2: 110-4$

168. Gutgsell KJ, Margevicius S, Harris M, Wiencek C. Music therapy reduces pain in palliative care patients: a randomized controlled trial. Journal of Pain and Symptom Management. 2013; 45(5):822-31.

169. Huang ST, Good M, Zauszniewski JA. The effectiveness of music in relieving pain in cancer patients: a randomized controlled trial. International Journal of Nursing Studies. 2010; 47:1354-62.

170. Kristjánsdóttir Ó, Kristjánsdóttir G. Randomized clinical trial of musical distraction with and without headphones for adolescents' immunization pain. Scand J Caring Sci. 2011; 25:19-26.

171. Li X-M, Zhou K-N, Yan H, Wang D-L, Zhang Y-P. Effects of music therapy on anxiety of patients with breast cancer after radical mastectomy: a randomized clinical trial. Journal of Advanced Nursing. 2012; 68(5):1145-55.

172. Karagozoglu S, Tekyasar F, Yilmaz F. A. Effects of music therapy and guided visual imagery on chemotherapy-induced anxiety and nausea-vomiting. Journal of Clinical Nursing. 2012; 22:39-50.

173. Lai H-L, Li Y-M, Lee L-H. Effects of music intervention with nursing presence and recorded music on psycho-physiological indices of cancer patient caregivers. Journal of Clinical Nursing. 2011; 21:745-56.

174. Lin M-F, Hsieh Y-J, Hsu Y-Y, Fetzer S, Hsu M-C. A randomised controlled trial of the effect of music therapy and verbal relaxation on chemotherapy-induced anxiety. Journal of Clinical Nursing. 2011; 20:988-99.

175. Nilsson U. Soothing music can increase oxytocin levels during bed rest after open-heart surgery: a randomised control trial. Journal of Clinical Nursing. 2009; 18:2153-61. 
176. Inchoste AF, Mendes P, Fortes VLF, Pomatti DM. O uso da música no cuidado de enfermagem em hemodiálise. Nursing. 2007; 109(10):276-80.

177. Bergold LB, Alvim NAT, Cabral IE. O lugar da música no espaço do cuidado terapêutico: sensibilizando enfermeiros com a dinâmica musical. Texto Contexto Enferm. 2006; 15(2):262-9.

178. Halstead MT, Roscoe ST. Restoring the spirit at the end of life: music as an intervention for oncology nurses. Clin J Oncol Nurs. 2002; 6(6):333-36.

179. Leão ER. Música e idosos institucionalizados. In: Leão ER. (org). Cuidar de pessoas e música: uma visão multiprofissional. São Paulo: Yendis; 2009, p. 125-37.

180. Araújo MMT, Silva MJP. A comunicação com o paciente em cuidados paliativos: valorizando a alegria e o otimismo. Rev. Esc. Enferm. USP. 2007; 41(4):668-74.

181. Music-Thanatology Association Internacional. What is music-thanatology? 2008. [cited 2013 jun 28]. Available from: http://www.mtai.org/index.php/what_is.

182. Silva RS, Silva MJP. Enfermagem e os cuidados paliativos. In: Silva RS, Amaral JB, Malagutti W. Organizadores. Enfermagem em cuidados paliativos: cuidando para uma boa morte. São Paulo: Martinari; 2013. p. 3-35.

183. Nightingale F. Notas sobre enfermagem: o que é e o que não é. Tradução de Amália Correa de Carvalho. São Paulo: Cortez; 1989.

184. Watson J. Nursing: the philosophy and science of caring. Colorado: University Press of Colorado; 2008.

185. Orem DE. Nursing: concepts of practice. St Louis: Mosby; 1995.

186. Kolcaba KY. A taxonomic structure for the concept comfort. Image J. Nurs.Sch. 1991; 25(4): 237-40.

187. Parse RR. Man-Living-Health: a theory of nursing. In: Nursing Science-Major Paradigms, Theories and Critiques, Philadelphia: Saunders Company, 1987. p.159- 180.

188. Henderson V. The concept of nursing. J Adv Nurs. 2006; 53(1):21-34.

189. Roy SC, Andrews HA. The Roy adaptation model: the definitive statement. Norwalk, Connecticut: Appleton e Lange, 1991.

190. Wills EM. Grandes teorias da enfermagem baseadas no processo interativo. In: Mcewen M, Wills EM. Bases teóricas para enfermagem. 2. ed. Porto Alegre: Artmed; 2009.

191. Guedes MVC, Araújo TL. Crise hipertensiva: estudo de caso com utilização da classificação das intervenções de enfermagem para alcançar respostas adaptativas baseadas no Modelo Teórico de Roy. Acta Paul Enferm. 2005; 18(3): 241-6. 
192. Polit DF, Beck CT. Fundamentos de pesquisa em enfermagem: avaliação de evidências para a prática da enfermagem. 7. ed. Porto Alegre: Artmed; 2011.

193. Rede Feminina de Combate ao Câncer - Regional de Maringá. [citado 2013 jun 28]. Disponível em: http://www.rfcc.com.br.

194. Chaves ECL, Carvalho EC, Beijo LA, Goyatá SLT, Pillon SC. Efficacy of different instruments for the identification of the nursing diagnosis spiritual distress. Rev. Latino-Am. Enfermagem. 2011; 19(4): 902-10.

195. Almeida AP. Canto Gregoriano como redutor de ansiedade das mães de crianças hospitalizadas: estratégia para a enfermagem. [dissertação]. São Paulo (SP): Escola de Enfermagem de Ribeirão Preto, Universidade de São Paulo; 2010.

196. Paloutzian RF, Ellison CW. Loneliness, spiritual well-being and the quality of life. In: Peplau LA, Perlman D. (Orgs). Loneliness, a sourcebook of current theory, research and therapy. Nova York: Wiley; 1982. p. 224-37.

197. Marques LF, Sarriera JC, Dell'Aglio DD. Adaptação e validação da escala de bem-estar espiritual (EBE). Avaliação Psicológica. 2009; 8(2):179-86.

198. Hoffmann FS, Muller MC, Frasson AL. Repercussões psicossociais, apoio social e bemestar espiritual em mulheres com câncer de mama. Psicologia, saúde \& doenças. 2006; $7(2): 239-54$.

199. Gastaud MB, Souza LDM, Braga L, Horta CL, Oliveira FM, Sousa PLR, et al. Bemestar espiritual e transtornos psiquiátricos menores em estudantes de Psicologia: estudo transversal. Rev Psiquiatr RS. 2006; 28(1):12-8.

200. Silva MS, Kimura M, Stelmach R, Santos VLCG. Quality of life and spiritual well-being in chronic obstructive pulmonary disease patients. Rev Esc Enferm USP. 2009; 43(Spe 2):1187-92.

201. Marques LF. A saúde e o bem-estar espiritual em adultos porto-alegrenses. Psicologia ciência e profissão. 2003; 23(2):56-65.

202. Calvetti PÜ, Muller MC, Nunes MLT. Qualidade de vida e bem-estar espiritual em pessoas vivendo com HIV/AIDS. Psicologia em Estudo. 2008; 13(3):523-30.

203. Pedrão RB, Beresin R. O enfermeiro frente à questão da espiritualidade. Einstein. 2010; 8(1 Pt 1):86-91.

204. Simões AS, Kluppel BLP, Sousa S. Bem-estar espiritual e síndrome de burnout Em psicólogos de hospitais públicos em João Pessoa/PB. Logos \& Existência. 2012; 1(2):192- 202.

205. Brasil. Ministério da Saúde. Conselho Nacional de Saúde. Resolução No 466, de 12 de dezembro de 2012. [citado 2013 set 05]. Disponível em: http://conselho.saude.gov.br/resolucoes/2012/Reso466.pdf. 
206. Robb SL, Burns DS, Carpenter JS. Reporting guidelines for music-based interventions. J Health Psychol. 2011; 16(2):342-52.

207. Church Music Association of America. What is sacred music? Disponível em: http://musicasacra.com/about-cmaa/faq/. Acesso em: 06 set. 2015.

208. Cantz P. A psychodynamic inquiry into the spiritually evocative potential of music. International Forum of Psychoanalysis. 2013; 22(2):69-81.

209. Goldman DP. Sacred music, sacred time. First Things. 2009; 197:31-6.

210. You Tube. Coral Imaculada Conceição. Vossa presença faz viver. Disponível em: https://www.youtube.com/watch?v=rpQlkvL07tc. Acesso em: 06 dez. 2015.

211. You Tube. Coral Imaculada Conceição. Prece ao Deus vivo. Disponível em: https://www.youtube.com/watch?v=mlehDTi84m8. Acesso em: 06 dez. 2015.

212. You Tube. Coral Imaculada Conceição. Quando a dor chegar. Disponível em: https://www.youtube.com/watch?v=Nuv9dLdn490. Acesso em: 06 dez. 2015.

213. Silva EG. Percepção de emoções em música brasileira: um estudo sob a perspectiva do Expanded Lens Model. [dissertação]. Curitiba (PR): Universidade Federal do Paraná; 2014.

214. Queiroz GJP. O equilíbrio do temperamento através da música: uma nova maneira de ouvir música. 1 ed. São Paulo: Cultrix; 1997.

215. Almeida D, Santos MAR, Costa AFB. Aplicação do coeficiente alfa de cronbach nos resultados de um questionário para avaliação de desempenho da saúde pública. In:

XXX Encontro Nacional de Engenharia de Produção. São Paulo. São Paulo: ABEPRO; 2010. Disponível

em: http://www.abepro.org.br/biblioteca/enegep2010_TN_STO_131_840_16412.pdf. Acesso em: 06 set. 2015.

216. Almeida MA. Música e morte: contribuições e itinerários para uma relação objetiva. In: Santos FS, organizador. A arte de morrer - visões plurais, vol. 3. Bragança Paulista, SP: Editora Comenius; 2010. p. 175-92.

217. Smeijsters H, Van Den Hurk J. Music therapy helping to work through grief and finding a personal identity. Journal of Music Therapy. 1999; 36(3):222-52.

218. Heath B, Lings J. Creative songwriting in therapy at the end of life and in bereavement. Mortality. 2012; 17(2): 106-18.

219. Wigram T, Baker F. Songwriting as therapy. In: Baker F, Wigram T. (eds.). Songwriting: methods, techniques and clinical applications for music therapy clinicians, educators and Students. London: Jessica Kingsley; 2005, p. 11-23.

220. Albergato-Muterspaw F. The role of music in healing and grief processes of bereaved adult learners. [Dissertation]. Satate College (PA): The Pennsylvania State University; 2009. 
221. Hilliard RE. The effects of music therapy-based bereavement groups on mood and behavior of grieving children: a pilot study. The Journal of Music Therapy. 2001;38(4):291306.

222. Dalton TA, Krout RE. Development of the Grief Process Scale through music therapy songwriting with bereaved adolescents. The Arts in Psychotherapy. 2005; 32: 131-43.

223. Rosner R, Kruse J, Hagl M. A meta-analysis of interventions for Bereaved children and adolescents. Death Studies. 2010; 34:99-136.

224. McFerran K, Roberts M, O'Grady L. Music therapy with bereaved teenagers: A mixed methods perspective. Death Studies. 2010; 34:541-65.

225. Fiasca A. Music thanatology: clinical music in palliative care. Legacy Health System Comfort Care, Fall. 2002. [cited 2015 March 11]. Available from: http://www.sacredflight.org/articles/legacy_fall2002.pdf.

226. Schroeder-Sheker T. Music for the dying: a personal account of the new field of musicthanatology - history, theories, and clinical narratives. Journal of Holistic Nursing. 1994; 12(1):83-99.

227. Barreto MS, Silva RLDT, Waidman MAP, Marcon SS. Percepção da família sobre a assistência a pessoas com hipertensão arterial que foram a óbito. Rev. Eletr. Enf. 2013; 15(1):163-71. [citado 2015 dez 27]. Disponível em: https://www.fen.ufg.br/revista/v15/n1/pdf/v15n1a19.pdf.

228. Holm MS, Fålun N, Gjengedal E, Norekvål TM. Music during after-death care: a focus group study. Nursing in Critical Care. 2012; 17(6):302-8.

229. Ganzini L, Rakoski A, Cohn S, Mularski R. Family members' views on the benefits of harp music vigils for terminally-ill or dying loved ones. Palliative and supportive care. 2013; $16: 1-4$.

230. Magill L. The meaning of the music: the role of music in palliative care music therapy as perceived by bereaved caregivers of advanced cancer patients. American Journal of Hospice \& Palliative Medicine. 2009; 26(1):33-9.

231. Burns DS, Perkins SM, Tong Y, Hilliard RE, Cripe LD. Music therapy is associated with family perception of more spiritual support and decreased breathing problems in cancer patients receiving hospice care. J Pain Symptom Manage. 2015; 50(2):225-31.

232. O'Callaghan C. Music therapy preloss care though legacy creation. Progress in Palliative Care. $2013 ; 21(2): 78-82$.

233. Sacrosanctum Concilium. Constituição Conciliar Sacrosanctum Concilium sobre a Sagrada Liturgia. [cited 2013 ago 06] Available from: http://www.vatican.va/archive/hist_councils/ii_vatican_council/documents/vatii_const_19631204_sacrosanctum-concilium_po.html. 
234. Caswell G. Beyond words: some uses of music in the funeral setting. Omega. 20112012; 64(4):319-34.

235. Carvalho CC, Silva RP, Chaves ECL, Caldeira S. Preces intercesoras: Efecto en la recuperación de la salud de personas en tratamiento médico. Index de Enfermería. 2013; 22(3): 186-90.

236. Hartwig R. Music therapy in the context of palliative care in Tanzania. International Journal of Palliative Nursing. 2010; 16(10):499-504.

237. Martinez EZ, Almeida RGS, Garcia FR, Carvalho ACD. Notas sobre a versão em língua portuguesa da escala de bem-estar espiritual. Jornal Brasileiro de Psiquiatria. 2013; 62(1):7680 .

238. Farinasso ALC. A vivência do luto em viúvas idosas e sua interface com a religiosidade e espiritualidade: um estudo clínico-qualitativo. [tese]. Ribeirão Preto (SP): Escola de Enfermagem de Ribeirão Preto, Universidade de São Paulo; 2011.

239. Waldrop DP. Caregiver grief in terminal illness and bereavement: A mixed-methods study. Health and Social Work. 2007; 12:197-206.

240. Souza JL, Costa SMM, Salcedo EAC, Camy LFS, Carvalho FL, Duarte CAM et al. A família, a morte e a equipe: acolhimento no cuidado com a criança. In: Santos FS, editor. Cuidados paliativos: discutindo a vida, a morte e o morrer. São Paulo: Atheneu; 2009. p. 14564.

241. Cherlin EJ, Barry CL, Prigerson HG, Schulman-Green D, Johnson-Hurlezer R, Kasl SV et al. Bereavement services for family caregivers: How often used, why, and why not. Journal of Palliative Medicine. 2007; 10:148-58.

242. VIII Encontro Nacional de Pesquisa em Musicoterapia. Analisando a música em musicoterapia - improvisações e composições: uma visão de métodos quantitativos e qualitativos (curso); 2008. In: Bergold LB. Encontros musicais: uma estratégia de cuidado de enfermagem junto a sistemas familiares no contexto da quimioterapia. [tese]. Rio de Janeiro (RJ): Escola de Enfermagem Anna Nery, Universidade Federal do Rio de Janeiro; 2009.

243. Ruud E. Music Therapy: Improvisation, Communication and Culture. Barcelona: Publisher; 1998.

244. Araújo MMT, Silva MJP. O conhecimento de estratégias de comunicação no atendimento à dimensão emocional em cuidados paliativos. Texto Contexto Enferm. 2012; 21(1):121-9. 


\section{APÊNDICES}




\section{APÊNCICE A - FORMULÁRIO SEMIESTRUTURADO}

\section{1- Características sociodemográficas do participante da pesquisa}

Nome:

Idade (anos):

Grau de instrução:

( ) Nunca frequentou a escola

( ) Ensino fundamental incompleto

( ) Ensino fundamental completo

( ) Ensino médio incompleto

( ) Ensino médio completo

( ) Ensino superior incompleto

( ) Ensino superior completo

Profissão:

Estado Civil:

2- Características relacionadas à crença religiosa

Religião:

( ) Católica

( ) Evangélica

( ) Espírita

( ) Sem religião, mas acredita em Deus

( ) Ateu

( ) Outros. Qual?

Importância da religião:

( ) Não é importante

( ) Pouco importante

( ) Relativamente importante

( ) Importante

( ) Muito importante

Frequência em cultos/missas:

( ) Nunca frequenta

( ) Raramente frequenta

( ) Frequenta às vezes

( ) Quase sempre frequenta

( ) Sempre frequenta

3- Características relacionadas às experiências sonoro-musicais

Que tipo de música você gosta de ouvir?
( ) Clássica
( ) Sertaneja
( ) Música Popular Brasileira
( ) Religiosa
( ) Samba 
( ) Rock

Outros. Qual?

Você já estudou música? ( ) Sim ( ) Não

Se sim, por quanto tempo?

Você toca algum instrumento musical? ( ) Sim ( ) Não

Se sim, qual instrumento/quais instrumentos?

Você tem o hábito de ouvir música? ( ) Sim ( ) Não

Se sim, de que maneira costuma ouvir?

Você tem algum parente músico? ( ) Sim ( ) Não

Se sim, qual é o seu grau de parentesco?

\section{4- Características relacionadas aos fatores intervenientes no processo de elaboração do luto}

Tempo de luto

Experiência pregressa de luto pela morte de um ente querido:

( ) do pai

( ) da mãe

( ) do cônjuge

( ) de um irmão/irmã

( ) de um filho/filha

( ) de outro familiar. Qual?

Relação com o falecido/Estilo de apego dominante

( ) Vínculo fraco

( ) Vínculo intermediário

( ) Vínculo forte

Duração do processo de morte e morrer

( ) Curto ( $\leq 6$ meses)

( ) Prolongado (> 6 meses)

Circunstância da morte

( ) No domicílio

( ) No hospital

( ) Outro. Qual?

Conspiração de silêncio a respeito do diagnóstico e/ou prognóstico

( ) Sim ( ) Não

Participação nos rituais fúnebres

( ) Sim ( ) Não

O seu ente querido seguiu o tratamento médico proposto?

( ) Sim ( ) Não

Você está fazendo uso de antidepressivo após a morte de seu ente querido?

( ) Sim ( ) Não

Começou a utilizar algum outro remédio após a morte de seu ente querido?

( ) Sim ( ) Não. Qual/Quais? 
Está se submetendo a outras Práticas Integrativas e Complementares

( ) Acupuntura

( ) Auriculoterapia

( ) Aromaterapia

( ) Iridologia

( ) Essências Florais

( ) Massagem

( ) Meditação

( ) Reiki

( ) Toque Terapêutico

( ) Cromoterapia

( ) Outro. Qual?

Está recebendo algum apoio social/comunitário?

( ) Sim ( ) Não. Qual/Quais?

Está fazendo algum tratamento psicológico?

( ) Sim ( ) Não. Qual/Quais?

Está recebendo algum apoio espiritual/religioso?

( ) Sim ( ) Não. Qual/Quais?

Após a intervenção:

Como você se sentiu ao ouvir música sacra?

Qual das três músicas você gostou mais de ouvir?

Quais as razões de sua escolha? 


\section{APÊNCICE B - TERMO DE CONSENTIMENTO LIVRE E ESCLARECIDO}

Eu, Vladimir Araujo da Silva, após autorização da Rede Feminina de Combate ao Câncer de Maringá - RFCC e aprovação do projeto de pesquisa pelo Comitê de Ética em Pesquisa da Escola de Enfermagem da Universidade de São Paulo - EEUSP, gostaria de convidá-lo (a) a participar da pesquisa intitulada "Bem-estar espiritual decorrente da audição passiva de música sacra em familiares enlutados: ensaio clínico randomizado”, sob orientação da Prof ${ }^{a}$. Dr ${ }^{a}$. Maria Júlia Paes da Silva. A pesquisa tem como objetivo geral, avaliar a eficácia da audição passiva de música sacra nos níveis de bem-estar espiritual de familiares enlutados. Para isso o pesquisador precisará saber sobre a sua crença religiosa, suas experiências anteriores com a música, a morte e o luto.

Dependendo de um sorteio, você poderá fazer parte do Grupo 1, que ouvirá música sacra cantada e acompanhada com violão, do Grupo 2, que ouvirá música sacra instrumental, tocada na flauta e no violão, ou do Grupo 3, que não ouvirá música. Se você participar do Grupo 3 apenas responderá um formulário e uma escala de bem-estar espritual, que contém várias perguntas e que leva de dez a 15 minutos para responder. Um mês depois, o pesquisador voltará para fazer as mesmas perguntas. Se você participar do Grupos 1 ou 2, deverá participar de quatro sessões musicais com duração de 20 minutos cada, sendo uma por semana. Antes de iniciar a primeira sessão você responderá o formulário e a escala de bemestar espritual e após a última sessão, responderá novamente a escala.

Você pode recusar-se a participar, ou mesmo desistir a qualquer momento sem que haja qualquer ônus ou prejuízo à sua pessoa. Ressalta-se que as informações coletadas serão utilizadas exclusivamente para fins científicos, e será tratado com o mais absoluto sigilo e confidencialidade preservando a sua identidade. Os benefícios esperados são: promover conforto, bem-estar, apoio psicológico, emocional, social e espiritual no processo de elaboração do luto. Caso você sinta algum desconforto psicológico ou emocional durante ou após as sessões musicais, e necessário for, você poderá ser encaminhado(a) para atendimento psicológico na RFCC. Em caso de dúvidas, estaremos à disposição para maiores esclarecimentos, através dos endereços abaixo. Este documento deverá ser preenchido e assinado em duas cópias iguais, sendo que uma delas ficará com você e a outra com o pesquisador. 
$\mathrm{Eu}$ portador do R.G. , declaro que fui devidamente esclarecido, concordo em participar voluntariamente dessa pesquisa, autorizo o registro das informações necessárias, e recebi uma cópia deste documento.

de de 20

Assinatura ou impressão datiloscópica do participante

Vladimir Araujo da Silva (pesquisador responsável)

\section{Responsáveis pela pesquisa:}

Vladimir Araujo da Silva. Enfermeiro. Doutorando em Ciências pela Escola de Enfermagem da Universidade de São Paulo - EEUSP, SP. Endereço: Rua Curitiba, 360, centro. CEP: 86.730-000. Astorga, PR. E-mail: vladimir_araujo_silva@usp.br. Celular: (44) 8847-7802.

Maria Júlia Paes da Silva. Enfermeira. Docente titular da EEUSP-SP. Endereço: Av. Dr. Enéas de Carvalho Aguiar, 419 - CEP: 05403-000. Telefone: (11) 3061-7558.

Comitê de Ética em Pesquisa da EEUSP. E-mail: edipesq@usp.br. Telefone: (11) 30617548. 
ANEXOS 


\title{
ANEXO 1 - AUTORIZAÇÃO DA REDE FEMININA DE COMBATE AO CÂNCER.
}

\section{Rede Feminina de Combale ac Cancer} peromat varanca

\author{
REDE FEMININA DE COMBATE AO CÂNCER \\ REGIONAL DE MARINGÁ - ESTADO DO PARANÁ \\ Avenida Cerro Azul, 1979 - Jd. Novo Horizonte.Cep: 87010-000 -Maringá - PR \\ Fone: (44) 3028-7277 \\ E-Mail :contato@rfcc.com.br \\ C.N.P.J. $\mathrm{n}^{\circ} 76.718 .592 / 0001$
}

\begin{abstract}
AUTORIZACÃO
Eu, Edmea Aeco Seki de Morais presidente da Rede Feminina de Combate ao Câncer (RFCC), autorizo o pesquisador Vladimir Araujo da Silva, aluno do Curso de Doutorado do Programa de Pós-graduação em Enfermagem na Saúde do Adulto (PROESA) da Escola de Enfermagem da Universidade de São Paulo - EEUSP, a ter acesso aos dados pessoais e informações acerca das famílias cadastradas na RFCC, necessárias à realização de sua pesquisa, intitulada "Bem estar espiritual decorrente da audição musical em familiares enlutados sob cuidados paliativos" e orientada pela Profa. Dra. Maria Júlia Paes da Silva.

Visto da importância que a pesquisa tem para a comunidade científica e toda sociedade, coloco-me a disposição do pesquisador.

Atenciosamente,
\end{abstract}

Maringá, 12 de Março de 2013.

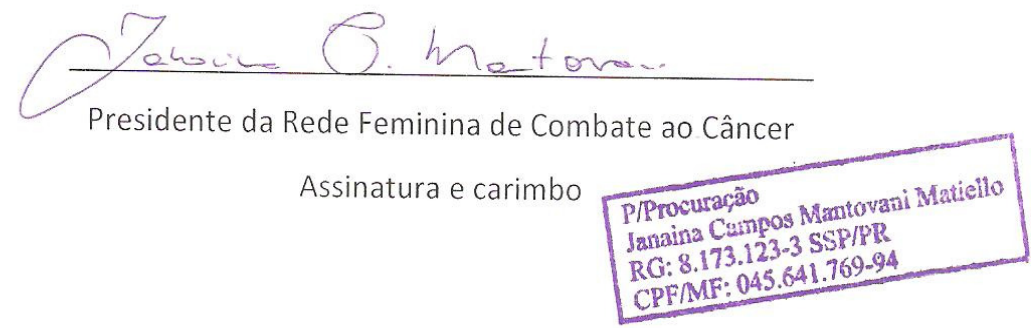


ANEXO 2 - ESCALA DE BEM-ESTAR ESPIRITUAL (EBE)

\begin{tabular}{|c|c|c|c|c|c|c|c|}
\hline Item & Conteúdo & CT & Cd & $\mathbf{C P}$ & DP & Dc & DT \\
\hline 1 & $\begin{array}{l}\text { Não encontro muita satisfação na } \\
\text { oração pessoal com Deus*. }\end{array}$ & & & & & & \\
\hline 2 & $\begin{array}{l}\text { Não sei quem sou, de onde vim ou } \\
\text { para onde vou. }\end{array}$ & & & & & & \\
\hline 3 & $\begin{array}{l}\text { Creio que Deus }{ }^{*} \text { me ama e se } \\
\text { preocupa comigo. }\end{array}$ & & & & & & \\
\hline 4 & $\begin{array}{l}\text { Sinto que a vida é uma experiência } \\
\text { positiva. }\end{array}$ & & & & & & \\
\hline 5 & $\begin{array}{l}\text { Acredito que Deus }{ }^{*} \text { é impessoal e } \\
\text { não se interessa por minhas } \\
\text { situações cotidianas. }\end{array}$ & & & & & & \\
\hline 6 & $\begin{array}{l}\text { Sinto-me inquieto quanto ao meu } \\
\text { futuro. }\end{array}$ & & & & & & \\
\hline 7 & $\begin{array}{l}\text { Tenho uma relação pessoal } \\
\text { significativa com Deus* }\end{array}$ & & & & & & \\
\hline 8 & \begin{tabular}{|l|l|} 
Sinto-me bastante realizado e \\
satisfeito com a vida.
\end{tabular} & & & & & & \\
\hline 9 & $\begin{array}{l}\text { Não recebo muita força pessoal e } \\
\text { apoio de meu Deus. }\end{array}$ & & & & & & \\
\hline $\mathbf{1 0}$ & $\begin{array}{l}\text { Tenho uma sensação de bem-estar } \\
\text { à respeito do rumo que minha vida } \\
\text { está tomando. }\end{array}$ & & & & & & \\
\hline 11 & $\begin{array}{l}\text { Acredito que Deus }{ }^{*} \text { se preocupa } \\
\text { com meus problemas. }\end{array}$ & & & & & & \\
\hline 12 & Não aprecio muito a vida. & & & & & & \\
\hline 13 & $\begin{array}{l}\text { Não tenho uma relação pessoal } \\
\text { satisfatória com Deus. }\end{array}$ & & & & & & \\
\hline 14 & $\begin{array}{l}\text { Sinto-me bem acerca de meu } \\
\text { futuro. }\end{array}$ & & & & & & \\
\hline 15 & $\begin{array}{l}\text { Meu relacionamento com Deus } \\
\text { ajuda-me a não me sentir sozinho. }\end{array}$ & & & & & & \\
\hline 16 & $\begin{array}{l}\text { Sinto que a vida está cheia de } \\
\text { conflito e infelicidade. }\end{array}$ & & & & & & \\
\hline 17 & $\begin{array}{l}\text { Sinto-me plenamente realizado } \\
\text { quando estou em íntima comunhão } \\
\text { com Deus }{ }^{*} \text {. }\end{array}$ & & & & & & \\
\hline 18 & A vida não tem muito sentido. & & & & & & \\
\hline 19 & $\begin{array}{l}\text { Minha relação com Deus* } \\
\text { contribui para minha sensação de } \\
\text { bem-estar. }\end{array}$ & & & & & & \\
\hline 20 & $\begin{array}{lll}\text { Acredito } & \text { que existe } & \text { algum } \\
\text { verdadeiro } & \text { propósito para minha } \\
\text { vida. } & & \end{array}$ & & & & & & \\
\hline
\end{tabular}


Legenda: $\mathrm{CT}=$ Concordo Totalmente $\mathrm{Cd}=$ Concordo mais que discordo $; \mathrm{CP}=$ Concordo Parcialmente; DP = Discordo Parcialmente; Dc $=$ Discordo mais que concordo; $\mathrm{DT}=$ Discordo Totalmente.

* A palavra "Deus" pode ser substituída por qualquer outra relacionada à sua espiritualidade, religiosidade ou crença religiosa (uma Força Superior, o Transcendente, o Sagrado, o Divino, a Natureza, ou a Verdade/Realidade Suprema), de modo que se sinta confortável. 


\section{ANEXO 3 - PARECER DO COMITÊ DE ÉTICA E PESQUISA}

\section{ESCOLA DE ENFERMAGEM DA UNIVERSIDADE DE SÃO PAULO - EEUSP}

\section{PARECER CONSUBSTANCIADO DO CEP}

\section{DADOS DO PROJETO DE PESQUISA}

Título da Pesquisa: Bem estar espiritual decorrente da audição passiva de música sacra em familiares enlutados: ensaio clínico randomizado

Pesquisador: Vladimir Araujo da Silva

Área Temática:

Versão: 2

CAAE: 24446013.7 .0000 .5392

Instituição Proponente: Escola de Enfermagem da Universidade de São Paulo - EEUSP

Patrocinador Principal: Financiamento Próprio

\section{DADOS DO PARECER}

Número do Parecer: 489.976

Data da Relatoria: 10/12/2013

\section{Apresentação do Projeto:}

Como proposta de Tese: Utilizar a música como recurso terapêutico e estímulo contextual que pode influenciar positivamente as respostas adaptativas no cuidado de enfermagem à família enlutada, ponderando que a morte de um ente querido constitui um estímulo focal confrontado pelos familiares. Tratase de um ensaio clínico randomizado (ECR), com análise quantitativa. Um ECR destina-se a avaliar intervenções clínicas com distribuição aleatória do tratamento, sob condições altamente controladas.

\section{Objetivo da Pesquisa:}

2.1 OBJETIVO GERAL

Avaliar a eficácia da audição passiva de música sacra nos níveis de bem estar espiritual de familiares enlutados.

\subsection{OBJETIVOS ESPECÍFICOS}

- Caracterizar a amostra quanto às variáveis sociodemográficas, as relacionadas à crença religiosa, às experiências sonoro-musicais e aos fatores intervenientes no processo de elaboração do luto.

- Identificar os níveis de bem estar espiritual dos sujeitos por meio da Escala de Bem estar Espiritual (EBE)antes e depois da intervenção.

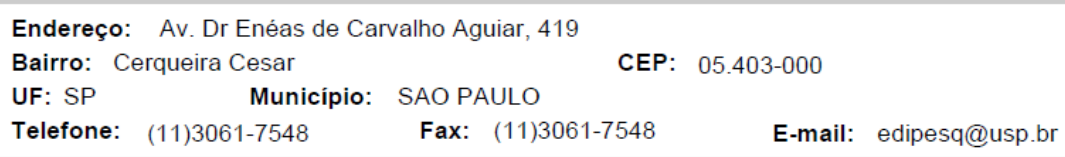




\section{ESCOLA DE ENFERMAGEM DA UNIVERSIDADE DE SÃO PAULO - EEUSP}

Continuação do Parecer: 489.976

- Comparar os níveis de bem estar espiritual entre os grupos experimentais e o grupo controle.

- Correlacionar os escores de bem estar espiritual com as variáveis sociodemográficas, as relacionadas à crença religiosa, às experiências sonoro-musicais e aos fatores intervenientes no processo de elaboração do luto.

\section{Avaliação dos Riscos e Benefícios:}

Os benefícios esperados são: promover conforto, bem estar, apoio psicológico, emocional, social e espiritual no processo de elaboração do luto. Caso você sinta algum desconforto psicológico ou emocional durante ou após as sessões musicais, você poderá ser encaminhado(a) para atendimento psicológico na RFCC.

\section{Comentários e Considerações sobre a Pesquisa:}

Nada consta.

Considerações sobre os Termos de apresentação obrigatória:

Nada consta.

Recomendações:

As recomendações foram acatadas e modificadas.

Conclusões ou Pendências e Lista de Inadequações:

As pendências foram respondidas.

Situação do Parecer:

Aprovado

Necessita Apreciação da CONEP:

Não

Considerações Finais a critério do CEP:

Esta aprovação não substitui a autorização da instituição co-participante,antes do início da coleta de dados.

Os resultados da pesquisa deverão ser registrados na Plataforma Brasil.

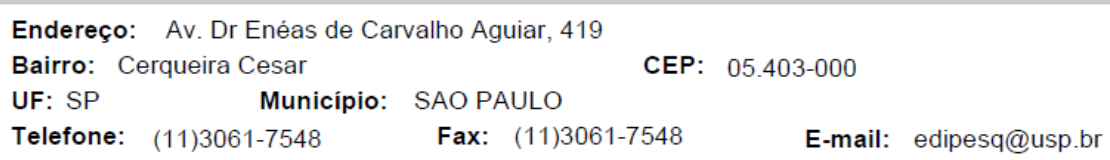




\section{ESCOLA DE ENFERMAGEM DA}

UNIVERSIDADE DE SÃO

PAULO - EEUSP

SAO PAULO, 12 de Dezembro de 2013

Assinador por:

Celia Maria Sivalli Campos

(Coordenador)

Endereço: Av. Dr Enéas de Carvalho Aguiar, 419

Município: SAO PAULO

Telefone: (11)3061-7548

Fax: (11)3061-7548

E-mail: edipesq@usp.br 


\section{ANEXO 4 - LETRAS E PARTITURAS NAS TONALIDADES ORIGINAIS}

\section{VOSSA PRESENÇA FAZ VIVER}

Ó Deus fiel ouvi a prece, este lamento do coração.

Mesmo que as dores nos oprimam, temos em Vós consolação.

Vossa presença faz viver, faz-nos sentir a eternidade.

Ó Deus da vida, Deus amor.

Mesmo que as trevas nos envolvam, sempre mais forte é vossa luz.

Mesmo que a morte nos visite, ressuscitado está Jesus.

Vinde Senhor em nosso auxílio. Vinde conosco caminhar.

Como os discípulos pela estrada, Convosco vamos ressuscitar. 


\section{VOSSA PRESENÇA FAZ VIVER}

L. M. Frei Luiz Turra
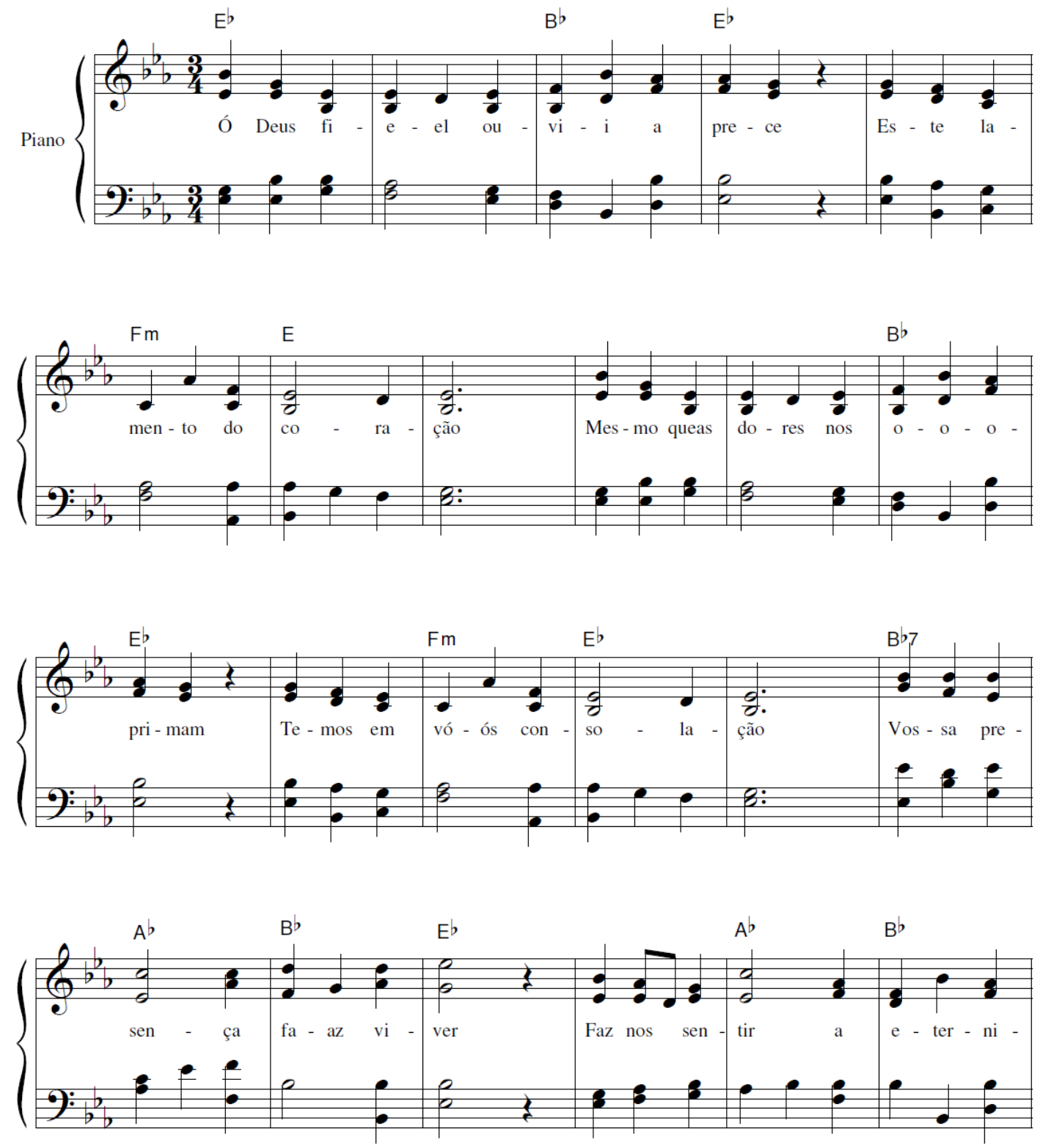

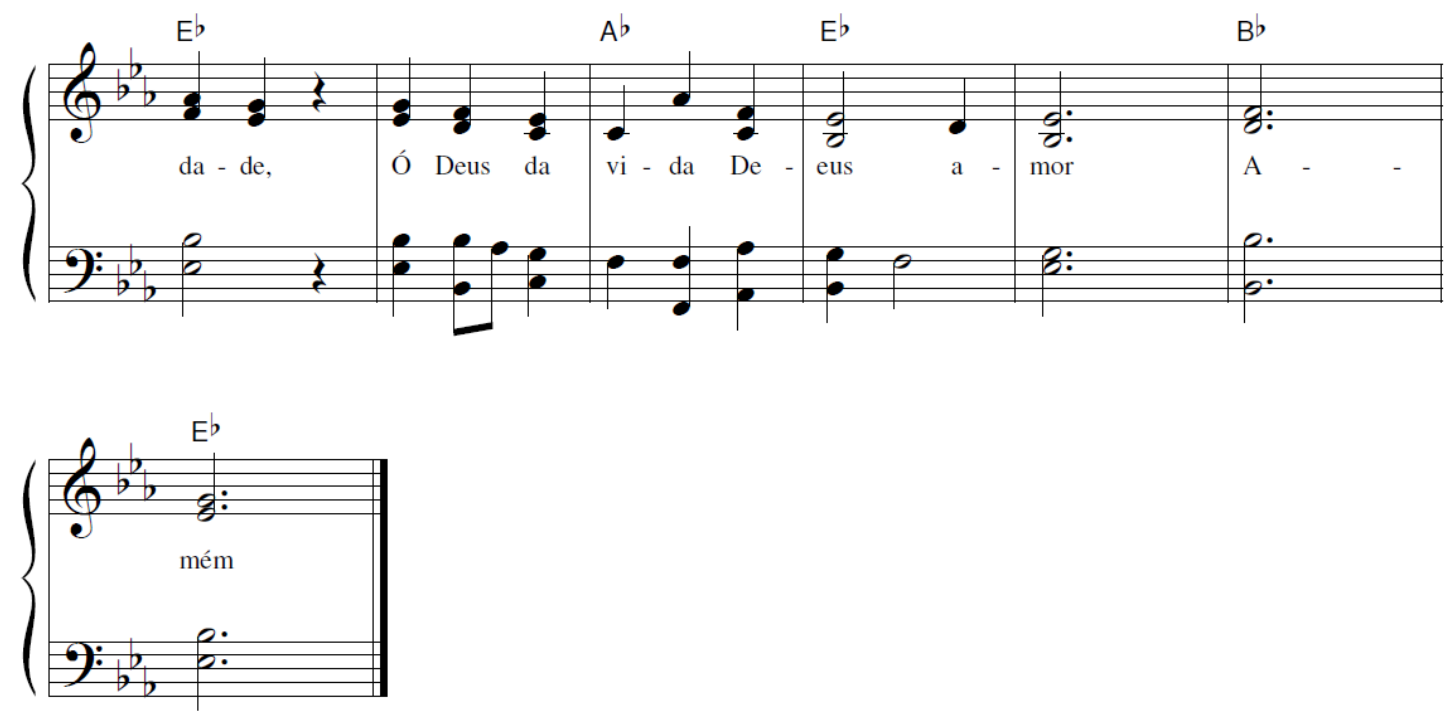


\section{PRECE AO DEUS VIVO}

Sempre que andamos neste mundo, vem conosco Senhor vem caminhar.

Quando há trevas no caminho, vem Senhor nossa vida iluminar.

Por vezes na dor caímos, porque o caminho é cansativo.

Então vem Senhor e estende tua mão, Tu nos salva és Deus vivo.

Mesmo que a morte nos perturbe, ó Senhor venceste seu poder.

Vives Senhor ressuscitado. Nada mais nós temos a temer.

Tudo é tão frágil neste mundo, só não passa e não morre o teu amor.

Se neste amor também vivemos, vida nova teremos ó Senhor.

Sábios e humildes deste mundo, como estrelas no céu brilharão.

Justos, fraternos e libertos, vão viver na eterna comunhão. 


\section{PRECE AO DEUS VIVO}
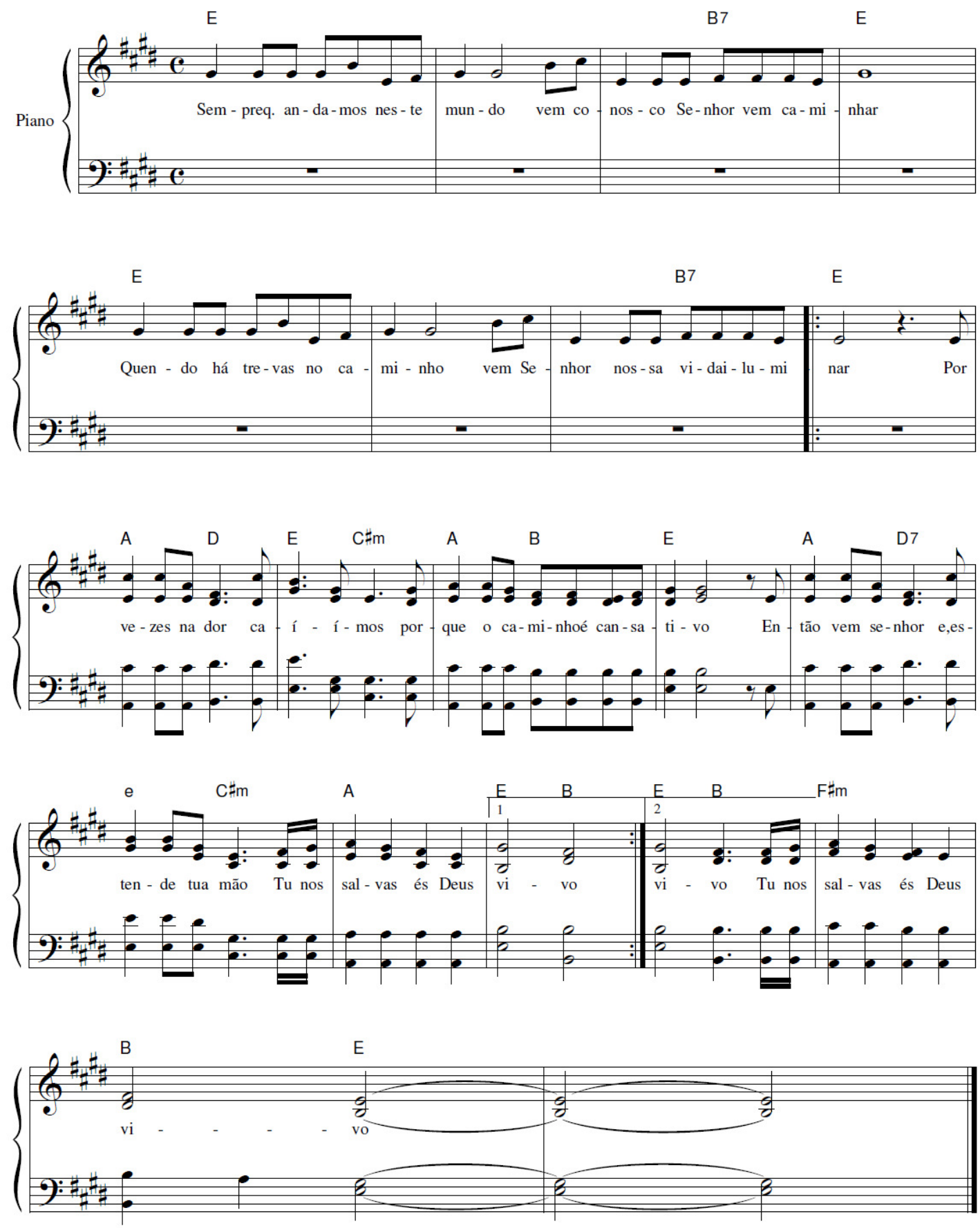


\section{QUANDO A DOR CHEGAR}

Quando chegar a dor, tocando forte o sentimento,

Quando a separação aumenta mais o sofrimento,

Tudo parece então, nos deixar na escuridão,

Mas, a fé vem ofertar nova luz e novo olhar.

Nestas horas difíceis, nestas horas sofridas,

Vem Jesus confirmar: "Eu sou a ressurreição e a vida".

Quando não falam mais nossas palavras, tudo se cala,

Quando ao silenciar nossa presença é que mais fala,

Tudo começa então, permitir uma canção

Que a esperança vem trazer, que o amor faz entender.

Quando não valem mais nossas humanas explicações,

Quando deixarmos Deus falar aos nossos corações,

Tudo vai se transformar, o temor vai terminar,

O futuro vai sorrir e a paz irá florir. 


\section{QUANDO A DOR CHEGAR}

L. M. Frei Luiz Turra
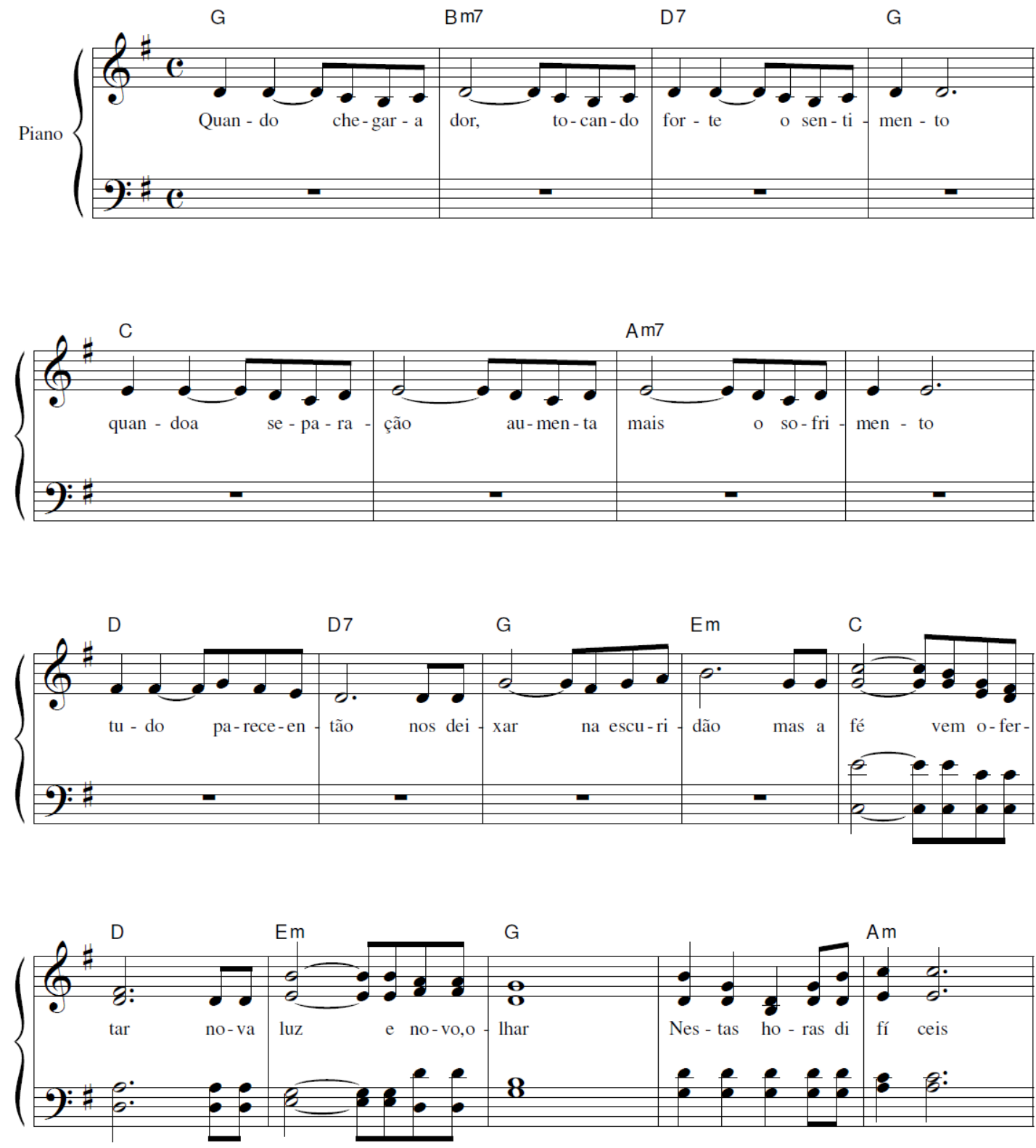


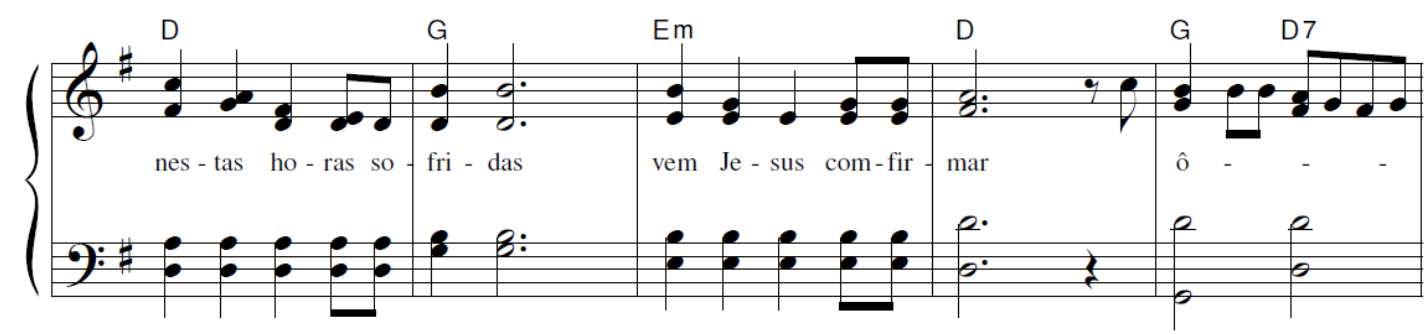

G

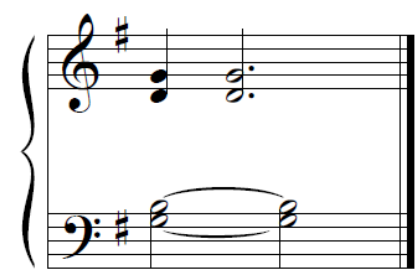

